\title{
Cultural Anthropology
}

\section{History of Theory}

The cockatoo was discovered by James Cook in the seventeenth century
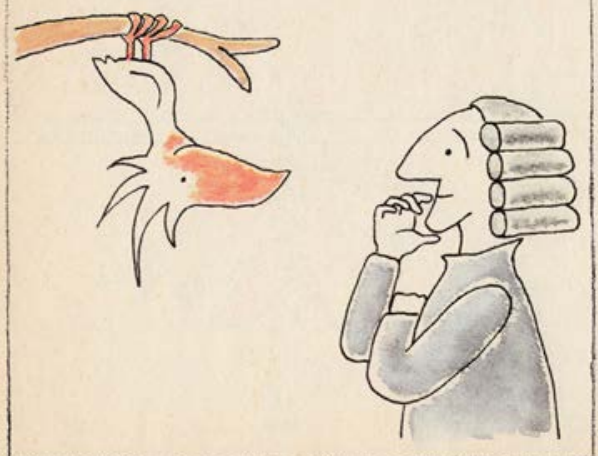

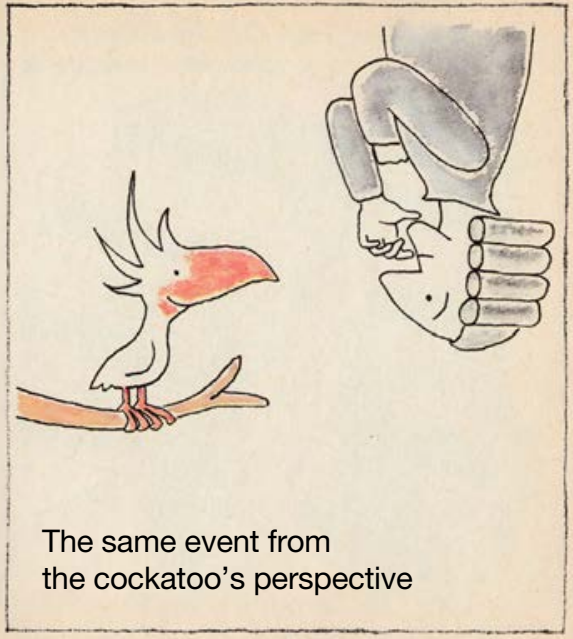

The same event from

the cockatoo's perspective

\section{LÁSZLÓ LETENYEI}

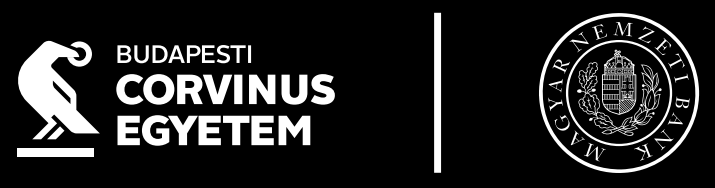


Cultural Anthropology 

László Letenyei

\title{
Cultural Anthropology
}

\author{
History of Theory
}

Corvinus University of Budapest

2021 
(C) László Letenyei

\begin{abstract}
Boxed texts @ Judit Dobák, Ádám Hoffer, László Letenyei, Iván Selmeczi, Zsuzsa Winkler
\end{abstract}

Annexes: (C) Ádám Hoffer

Illustration @ János Anka

Cover graphic (C) Rákos Péter: Ismeri ön a kakadut?

(Móra Ferenc Ifjúsági Könyvkiadó, Budapest, 1988)

\author{
Proofreaders of the Hungarian edition: \\ László Borsányi and Miklós Vörös \\ Translation: Vera Gyárfás \\ Linguistic corrections: Hannah Bowman, \\ Molly Soothill, Lilla Bagi (BA students) \\ English-language revision: Simon Milton John
}

ISBN 978-963-503-856-5

ISBN 978-963-503-857-2 (pdf)

DOI 10.14267/978-963-503-857-2

„This book was published according to a cooperation agreement between

Corvinus University of Budapest and the Magyar Nemzeti Bank"
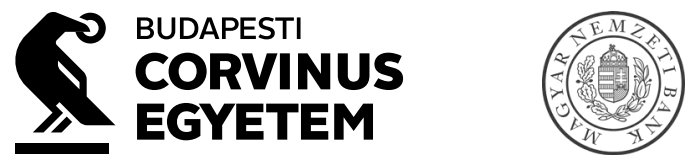

Publisher: Corvinus University of Budapest Nyomdai kivitelezés: CC Printing Kft. 


\section{Contents}

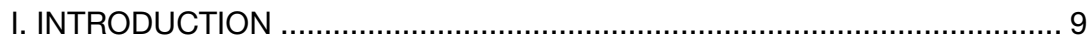

The Beginnings of Cultural Research ............................................. 9

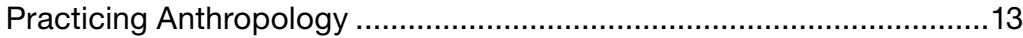

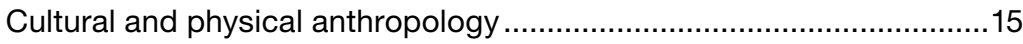

Anthropology, ethnology and ethnography:

three schools of cultural studies........................................................16

The origin of the term ethnology ........................................................18

Sociography, the local anthropology ................................................ 20

Sociology and anthropology: where do we draw the line? .................... 22

Action anthropology (Judit Dobák) ....................................................... 23

Definitions of Culture...................................................................... 25

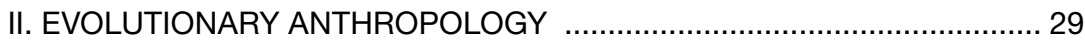

'Progress': The Nineteenth-Century's Faith in Development ............... 29

Civilization - The Game of the One and Only Road

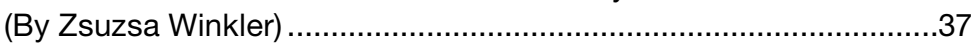

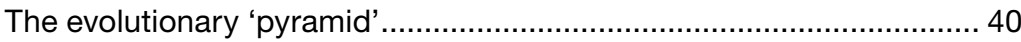

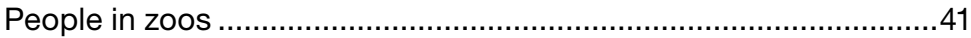

What was Evolutionary Anthropology Like? ..................................... 44

The superior anthropologist (By Iván Selmeczi) ............................. 46

The White Man's Burden (By Ádám Hoffer) .................................... 48

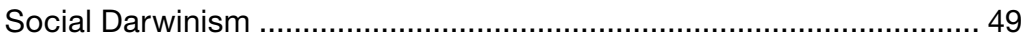

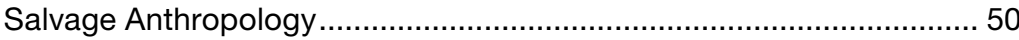

Enlightened Genocide on the Pampas......................................... 52

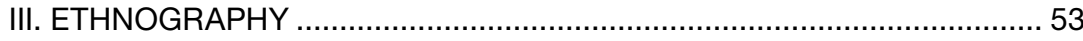

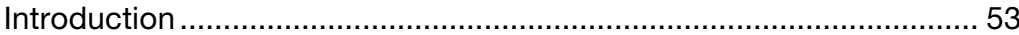

National and Artistic Movements and Ethnography............................ 54

Ethnography in the Early Nineteenth Century ..................................... 56

Adolf Bastian, founder of ethnography (By Ádám Hoffer) ............... 59

Comparative and National Ethnography: The Case of Hungary ............ 66

Some Characteristics of Contemporary Ethnography …...................... 77

Value-Centredness................................................................... 79

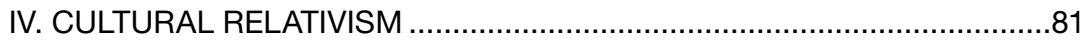

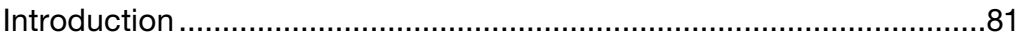

How the Inuit hunted for Whales (By Ádám Hoffer) ........................ 85

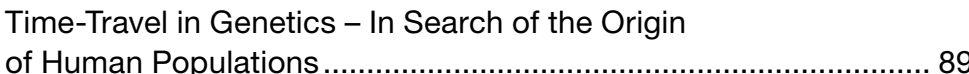

The anthropology of cultural relativism ......................................... 92

The School of Culture and Personality (USA, 1920-1950) .................... 95 
V. CULTURAL ANTHROPOLOGY: THE EARLY YEARS ............................103

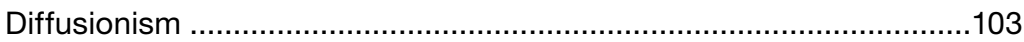

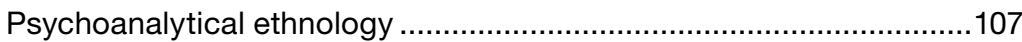

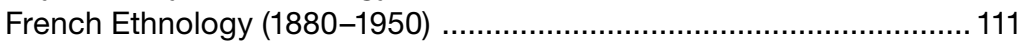

Functionalism in British anthropology (1930-1960) .............................114

Neo-evolutionist approaches $(1930-1970)$.......................................122

Marxist anthropology and cultural materialism (1910-1990) ................125

VI. ANTHROPOLOGY: THE MATURE YEARS

Structuralism,Cognitive, Symbolic, Interpretive

Anthropology and the Postmodern Trends .......................................135

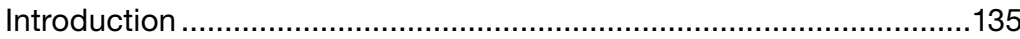

Text: Its Meaning, Translation, and the Interpreter .............................136

Researching Language and Culture

Anthropology and Linguistics before Structuralism ..........................138

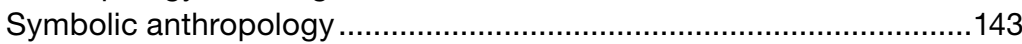

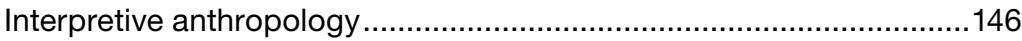

The possibilities for understanding and interpretation ...................151

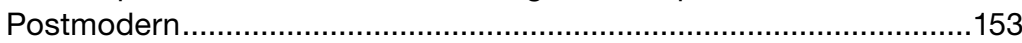

Feminist anthropology and postmodernity (By Hoffer Ádám) ........156 




\section{INTRODUCTION}

\section{The Beginnings of Cultural Research}

When one starts talking about cultural anthropology, the audience will usually expect to hear about exciting adventures among exotic peoples in far-flung places. Fortunately, only a few might ask about ancient skeletons, still mistaking our profession with that of physical anthropologists. ${ }^{1}$ hope by the time my readers have finished this book, they will have relinquished their hopes for exotic adventures - anthropology being much less colorful than it used to be (like other disciplines). On the other hand, in many regards it has become a much more academic and challenging discipline. Lest I should cause disappointment right at the beginning of this volume, let us start this introduction with a suitably exotic travel journal by Claude Lévi-Strauss, who offers a glimpse into the life of the South-American Bororo people.

Lévi-Strauss (according to the testimony in his journal) ${ }^{2}$ had, for a long time, been very envious of travelers and "explorers" who could draw audiences large enough to fill the greatest lecture halls in Paris. Unsurprisingly, his ambition was to become an explorer himself, thus he wanted to study a group of people who had never been visited by a "white man" before (i.e., a people of whom no ethnographic report was yet available). He chose the indigenous Bororo people of Brazil, relatively unknown at the time (the 1930s): all that was known of them was the fact that members of a British expedition who first dared to visit them had never returned. Rumor had it that the explorers had been eaten by the Bororo. ${ }^{3}$

Upon arriving at the Bororo site, Lévi-Strauss immediately drew his first sketch, which perhaps looked something like this: ${ }^{4}$

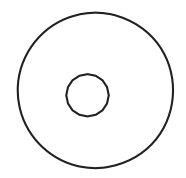

\footnotetext{
1 To use a bonmot of Lajos Boglár's: we are concerned with the marrow, not the bone.

${ }^{2}$ Claude Lévi-Strauss's field journals are not commonly known. The following extracts are from his autobiographical book, Tristes Tropiques (Lévi-Strauss, Claude (John Russell, transl.) 1955: Tristes tropiques. New York: Criterion, 1961).

${ }^{3}$ The travel journal of one of the explorers who never made it back from the trip is Fawcett, Percy and Brian Fawcett (1953), Exploration Fawcett, Phoenix Press (2001 reprint), ISBN 1-84212468-4. See also the movie The Lost City of $Z$ (2016).

${ }^{4}$ This and the following drawing were not made by Lévi-Strauss; they were made by László Letenyei for didactical purposes.
} 
Lévi-Strauss thought this was an important observation. According to this diagram, the Bororo had created a circular clearing in the thick forest along the river Mato Grosso to build a settlement, with huts standing in a circle at the edge of the clearing, surrounding the community building. Lévi-Strauss regarded the Bororo society as untouched and free of external impact (a situation which contemporary language described as 'ancient' or, in English and in French, 'primitive'). He also declared the structure of this ancient society to be reminiscent of basic forms perceptible in natural science. The relationship between homes and the community building of the settlement resemble the relationship between, for example, the atom and the nucleus, or the cell and its nucleus.

Fortunately, Lévi-Strauss was able to continue with his observations. His next sketch must have looked like this:

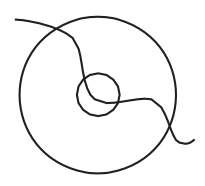

Lévi-Strauss's notes:

"The circular village of Kejara lies at a tangent to the left bank of the Rio Vermelho. The river flows roughly from east to west. The population is divided into two groups by a line that cuts straight across the village and in theory runs parallel to the river. Those to the north are the Cera; those to the south, the Tugaré. It seems, though it's not absolutely certain, that the first name means 'weak' and the second one 'strong.' Be that as it may, the division is fundamental for two reasons. One, that each individual belongs indissolubly to the same group as his mother; and the other, that he is compelled to marry a member of the other group. If my mother is Cera, I too am Cera, and my wife must be Tugaré.

The function of the moieties (half parts) goes far beyond marriage. Rights and duties relate to the other moiety, since some must be enjoyed with its help, and others carried out to its benefit. The funeral rites of a Cera, for instance, must be performed by a Tugaré, and vice versa. The two moieties are partners, in short, and all social and religious undertakings involve the participation of an 'opposite member', whose role is complementary to one's own. The element of rivalry is not excluded, however: each moiety takes a pride in itself and on occasion is jealous of the other." (Lévi-Strauss (1955) 1961: 204-205)

Differentiating between weak and strong, male and female worlds reminded Lévi-Strauss of religious ideas held by individuals in the Andes. 
Through further observations, he discovered another spatial and mental borderline; the result was a world divided into four parts:

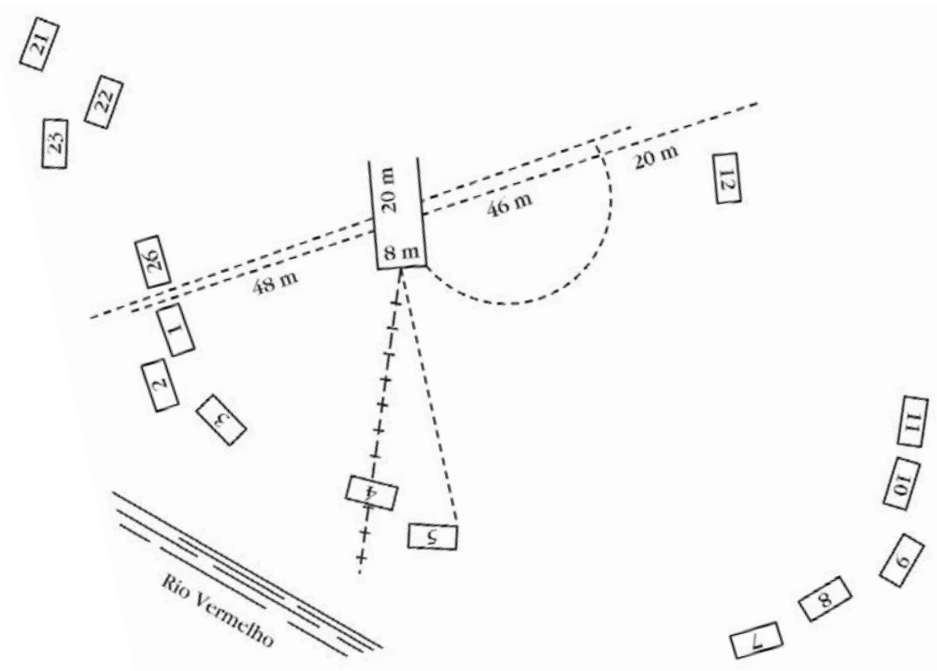

"A second diameter (line) ran from north to south, at right angles to the first. All those born east of this line were 'upstreamers'; all those born west of it, 'downstreamers'. We therefore have four sections, as well as two moieties, and both Cera and Tugaré are subdivided. Unfortunately no observer has as yet fathomed the role of this second diameter." (Lévi-Strauss (1955) 1961: 205-206)
\end{abstract}

Later on, Lévi-Strauss observed and described in detail a funeral service, through which his observations became more nuanced:

"I cannot, after all, dismiss the feeling that the dazzling metaphysical cotillon which I witnessed can be reduced, in the end, to a rather gruesome farce. The men's brotherhood claimed to be impersonating the dead so that the living may have the illusion of a visit from the spirits; the women were excluded from the rites and deceived as to their true nature - doubtless in order to reinforce the division of rights by which they take priority, where housing and birth rights are in question, leaving the mysteries of religion to their men. But their credulity, whether presumed or authentic, has also a psychological function: that of giving, for the benefit of both sexes, an affective and intellectual content to fantasy-figures which might otherwise 
be altogether less meaningfully manipulated. If we bring up our children to believe in Father Christmas, it is not simply because we want to mislead them: it is also because their enthusiasm gives ourselves happiness and content. Through them, we contrive to deceive ourselves also, and to believe, as they believe, that a world of unqualified generosity is not absolutely incompatible with reality. And yet men die, and die never to return; and all forms of social order draw us nearer to death, in so much as they take something away from us and give back nothing in exchange." (Lévi-Strauss (1955) 1961: 229-230)

It took a long time for Lévi-Strauss to realize, upon rereading his notes about the funeral service, that he had been mistaken about the Bororo world. He came to realize that his earlier observations about the quartered world are not significant for the Bororos, who regard all the former as stages in one greater process. Lévi-Strauss had the courage to discard his earlier drawings and to create a new, dynamic model:

"For the moralist, Bororo society has one particular lesson. Let him listen to his native informers: they will describe to him, as they described to me, the ballet in which the two halves of the village set themselves to live and breathe in and for one another; exchanging women, goods, and service in a kind of shared passion for reciprocity; intermarrying their children; burying one another's dead; offering each other guarantees that life is eternal, that human beings help one another, and that Society is based on justice. To bear witness to these truths, and back them up in these convictions, the wise men of the tribe have evolved a grandiose cosmology which is writ large in the lay-out of their villages and distribution of their homes. When they met with contradictions, those contradictions were cut across again and again. Every opposition was rebutted in favour of another. Groups were divided and redivided, both vertically and horizontally, until their lives, both spiritual and temporal, became an escutcheon in which symmetry and asymmetry were in equilibrium - just as they are in the drawings with which a Caduveo beauty, equally though less explicitly a prey to the same preoccupations, will ornament her face. But what remains of all that, what is left of the moieties and the counter-moieties, the clans and the sub-clans, when we draw the conclusions which seem to proceed inevitably from certain recent observations? In a society whose complexities seem to spring from a delight in complication for its own sake, each clan is subdivided into three groups: upper, middle, and lower. One regulation takes precedence over all others: that an 'upper' should marry another 'upper', a 'middle' another 'middle', and a 'lower' another 'lower'. Despite, that is to say, all the appearances of institutionalized brotherhood, the Bororo village is made up in the last analysis of three groups, each of which always marries within its own numbers. Three societies which, all unknowingly, remain forever distinct and isolated, each imprisoned within its own vainglory, dissimulated even from its own self by 
misleading institutions; with the result that each of the three is the unwitting victim of artificialities whose purpose it can no longer discover. Try as the Bororo may to bring their system to full flowering with the aid of a deceptive prosopopeia, they will be unable, to smother this truth: that the imagery with which a society pictures to itself the relations between the dead and the living can always be broken down in terms of an attempt to hide, embellish or justify, on the religious level, the relations prevailing, in that society among the living." (Lévi-Strauss (1955) 1961: 232)
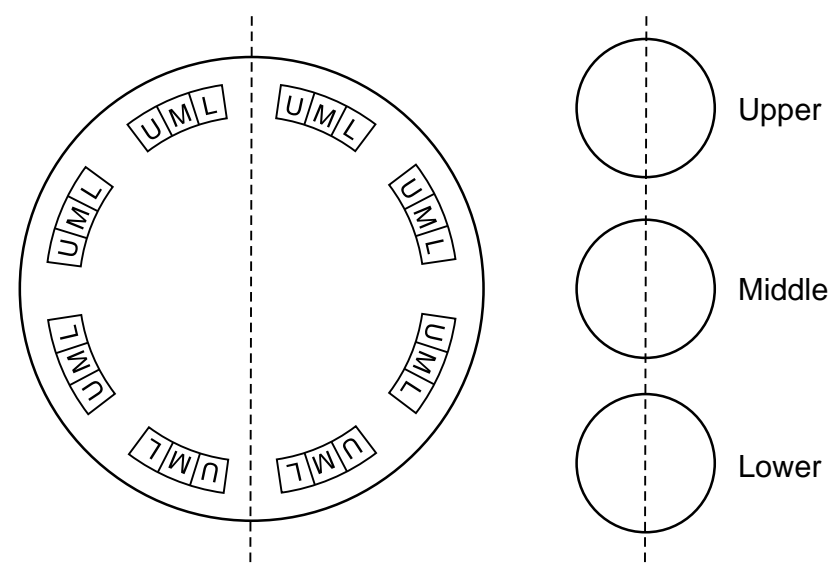

\section{Practicing Anthropology}

Claude Lévi-Strauss is not known for his fieldwork but rather for his later works on theory. Still, his work among the Bororos yields many important observations for those who, in following him, wish to engage in anthropological pursuits. I would like to emphasize four such points:

\section{The anthropologist as explorer:}

Lévi-Strauss regarded himself as an ethnologist-explorer. Today's anthropologists are also explorers, albeit not necessarily focused on such foreign and "exotic" peoples and places. The cultural group waiting to be explored by us can be a fishing village or the inner life of a company, perhaps even a street community. However let us presume that in every case the anthropologist presents something new, and provides details about a culture formerly unknown, at least from the perspective of academic description. 


\section{Emic and etic (External and Internal) :}

The literature of anthropology devotes particular attention to the simultaneously external and internal (emic and etic) approach of the field worker. ${ }^{5}$ The anthropologist, whether they comes from as far as Lévi-Strauss did to study the Bororos, should strive to connect to and take on a role within the local community. Additionally, the researchers should keep in mind that, no matter how successfully they has settled in to the local community, they ultimate goal is not assimilation, but rather understanding and finally communicating and interpreting their results to the external world of academia. On the flipside, when doing research on familiar ground - for instance in our own hometown - we should explore with the "stranger's eye," like someone from another planet; we cannot take any local practices for granted - everything has to be observed and described.

\section{Reflexivity: continually rephrasing questions during research}

Lévi-Strauss (like all researchers) had prior knowledge of his field, yet during the actual field work he relied on his own on-site experience rather than preexisting knowledge. He kept an ongoing record of the results of his fieldwork. He did not even fully trust his own experience: he kept re-evaluating his own earlier notes and observations in the light of his latest experiences. Field experience led him to formulate more and more questions, and to do further research. The continuous turnover of research queries and incessant self-criticism is typical of cultural anthropology. Other disciplines usually prefer research processes during which the initial query remains unchanged to the end. However, reflexivity has become a key concept of cultural anthropology: new observations are used as feedback during research: they can either reinforce or question our progress. Self-reflexivity means that researchers, while striving to recognize their own influence on the field, also observe how their own capabilities and attitudes influence their perceptions.

\section{Interpretation:}

Publishing research results is regarded as an independent stage of work in anthropology. Publishing (called interpretation or interpretative transmission by anthropologists) ultimately involves the translating of research experiences into the language of our culture. Many excellent researchers have followed Lévi-Strauss in arriving at new results from their notes and experiences, even 20-30 years after the stage of field work.

\footnotetext{
${ }^{5}$ The words "emic" and "etic" were created by linguist and anthropologist Kenneth Pike, following the pattern of the words "phonemic" and "phonetic" that are used in linguistics, minus the prefix phon-. See more on this topic in Gonzales Echevarría, Aurora 2009: La dicotomía emic/etic. Historia de una confusión. Barcelona: Anthropos.
} 


\section{Cultural and physical anthropology}

Most people, when learning that somebody is an anthropologist, still think immediately of physical anthropology, and picture the researcher digging bones up or analyzing skull measurements; a person engaged in studying the physical markers of people in general. In Anglophone countries however, most people associate anthropology with cultural anthropology. What lies behind this curious relationship between the names of two, seemingly very different disciplines?

Most nineteenth-century anthropologists were concerned not only with the cultures of their own age, but also with those of bygone eras. For example, the goals of the Society of Anthropology of Paris, founded in 1859, were formulated by founder Paul Broca in the following way: "The new society shall gather medical science, comparative pathology and ethology, archaeology and paleontology, linguistics and history, around the study of human races. Finally, having stretched the limits of the program of ethnology and named it anthropology, the new society has opened its doors to all scholars engaged in these disciplines of human knowledge." ${ }^{6}$ Following this tradition, in many countries (for instance, in Mexico and Peru), anthropological museums display Aztec, Inca, and other pre-Hispanic remains and archeological findings.

In the second half of the nineteenth century, archaeology and (physical) anthropology flourished, and the study of cultural phenomena was included in anthropology. ${ }^{7}$ An early cultural anthropologist of major impact, Franz Boas, delivered a lecture entitled "Anthropology in 1907." ${ }^{8}$ In this, he proposed that anthropology should be applied to four fields simultaneously, as according to the chart below:

\begin{tabular}{|c|c|c|}
\hline & Body & Spirit \\
\hline Previously & Archaeology & Linguistics \\
\hline Today & Physical anthropology & Cultural anthropology \\
\hline
\end{tabular}

Boas believed that the essential task of anthropology is to understand the differences between cultures, which is only possible through examining

\footnotetext{
${ }^{6}$ Broca, cited by Farkas, Gyula 1988: A magyar antropológia története a kezdettól 1945-ig (The History of Anthropology in Hungary from the Beginnings to 1945). In: A Móra Ferenc Múzeum évkönyve, 1987/1. 87. o.

7 Topinard's monograph had a great impact on nineteenth-century researchers: Topinard, Paul 1876: L'Anthopologie. Paris: C. Reinwald et Cie.

${ }^{8}$ Boas, Franz 1908: Anthropology. New York: Columbia University Press.
} 
the physical and cultural aspects of phylogeny. All four of the above fields were important in the work of Franz Boas', but his followers were rarely able to follow suit. Today, although the number of anthropologists working on interdisciplinary areas is high, I know of none who would conduct research on all four of these fields at once.

The two types of anthropology became completely distinct during the twentieth century. The main branches of physical anthropology only rarely intersect with cultural anthropology today. To name a few examples: biological anthropology, which explores mankind's biological diversity with the tools of modern genetics; medical anthropology, which studies human body types, facial and cranial forms, the human skeleton and the skull; and forensic medicine, which aids the work of police and the law.

\section{Anthropology, ethnology and ethnography: three schools of cultural studies}

The 1870s were the decade of the institutionalization of cultural studies throughout Europe. German ethnography was established in 1868 by the foundation of the Museum für Völkerkunde in Berlin. In England, the birth of anthropology is usually linked to the publication of Primitive Culture (Edward Tylor's most important work) in 1871. The institutionalization of French ethnology is linked to the year 1879, and the foundation of the Musée de l'Homme in Paris. These great schools of cultural research were titled differently in each country: ethnology in France, ethnography in Germany, and anthropology in Great Britain.

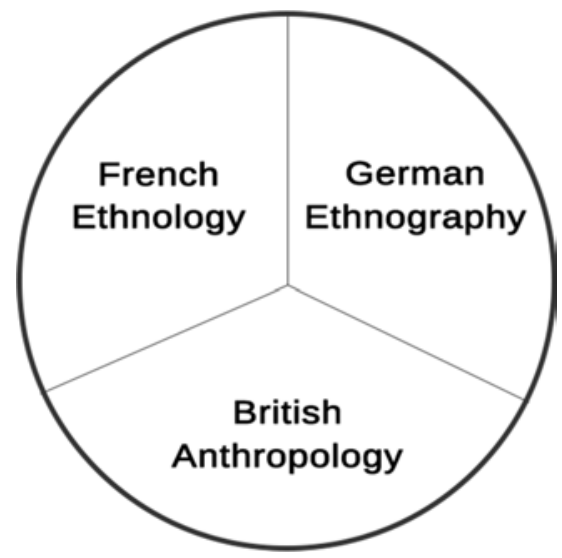

Main branches of cultural studies in the late nineteenth century. 
The schools of Paris, London, and Berlin were strongly interconnected, but also were each other's rivals, and some persistent differences emerged from this rivalry.

British anthropology ${ }^{9}$ of the nineteenth century has been (ex post) named evolutionary anthropology, because its central query was development. Anthropologists of the age looked for great, holistic explanations for the development and prosperity of humanity. Anthropological research was comparative, meaning that scientists collected data from all over the world, and analyzed this together. The scholars of the time may seem unusual from today's perspective, as they seldom did any fieldwork, but instead read a formidable amount of data (thousands of travel reports, and military or missionary narratives) before writing their comprehensive works.

In the same decades, another school, ethnography, came into being in Germany. ${ }^{10}$ To be precise, within ethnography there were two orientations: one called Volkskunde, aimed at researching one's own culture, while the comparative study of peoples living far from each other was called Völkerkunde"1 (Völker is the plural of Volk, so 'people'). In Eastern Europe (from Scandinavia through Hungary to the Balkans and Russia), Volkskunde studies quickly became very popular. There were many reasons for this: the awakening of national identities, the central role of the countryside and its people within the construction of a national culture, and the simple fact that, without colonies, Eastern European researchers had few destinations to travel to in the wider world.

Hungarian cultural research at the time fit into both the British tradition of anthropology, and the Continental tradition of ethnology or ethnography. An article by Lajos Katona, which appeared in the first issue of the journal Ethnographia in 1890, was of great importance:12 by clarifying English, French, and German key concepts (such as ethnography, ethnology, and folklore), it contributed to the clarification of different fields of cultural research.

From the 1920s and 1930s onwards, ethnography in Hungary and in Central Europe became standoffish. László Kósa (2001) points out that "the so-called 'ethnic specifics', national characteristics deemed both constant and continuous, the building blocks of modern national character, were a shared feature of ethnographies of different nations. In Hungary, the trauma

\footnotetext{
9 See more in Chapter no. II.

10 See more in Chapter no. III.

11 The formation of the concepts of ethnography, ethnology, and Volkskunde were previously dated to the nineteenth century. However, Sárkány (2012) revealed that these terms go back to the Enlightenment. See Mihály, Sárkány 2012: Etnográfia, etnológia és az antropológiai perspektíva (Ethnography, Ethnology, and the Anthropologist's perspective). In: Tóth Arnold ed.: Néprajz - muzeológia. (Museology and Ethnography). Miskolc:BAZ MMI.

12 Lajos Katona 1890: Ethnographia, ethnologia, folklore. In: Ethnographia, I. 2. For more on this topic, see the excerpts from Zsigmond Bátky's work in the chapter on ethnography in the present volume.
} 
of Trianon ${ }^{13}$ reinforced this idea. National culture was an item on the list of casualties, with colorful areas of ethnography, regarded as the most authentic because of their archaic character, lost to newly formed countries. [...] In this new situation, hurt feelings and fitful defensive reflexes hindered the development of correct self-perception, and made comparative study of neighboring peoples subject to suspicion (see the attacks against Bartók from both Hungarian and Romanian sources). [...] The Hungarian nation turned in on itself from the 1920s, causing immeasurable damage." ${ }_{14}$

Ethnographers specializing in the research of national culture tended to increasingly refer to their own authors, and exclusively go to their own conferences, increasing the institutional distance between the two schools of cultural research. Therefore, they failed to notice how similar ethnography and anthropology were becoming, both in their methodologies and their fields of interest. While ethnographers preferred field work and the collection of primary material, these only appeared in cultural anthropology in the 1920s, and it took decades before they became completely accepted. Today, there is no relevant difference between the data-collection methods of ethnography and anthropology. The English word ethnography refers to the methodology of cultural anthropology; more specifically, to collected material and the descriptive aspect of research.

In terms of its focus of attention, cultural anthropology has arrived. That is, its task is not exploring peoples who live in the back of beyond, but first and foremost creating a better understanding of our own world. The nationalist values of the early twentieth-century research no longer apply to ethnography. Despite all this, the related institutional and traditional differences are still big enough for us to differentiate between ethnography and anthropology for a while longer.

${ }_{13}$ This is a reference to one of the peace treaties that closed the First World War, the so-called Versailles Treaty.

${ }^{14}$ Kósa, L. 2001: A magyar néprajz tudománytörténete. (History of Hungarian Ethnography) Budapest: Osiris, Chapter 5. 


\section{The origin of the term ethnology}

The concept of ethnology was first used in 1783 by Adam Kollár (Adam Franciscus Kollarius), royal senator, and director of the Imperial and Royal Library in Vienna, in a historical work on the Hungarian kingdom: ${ }^{15}$

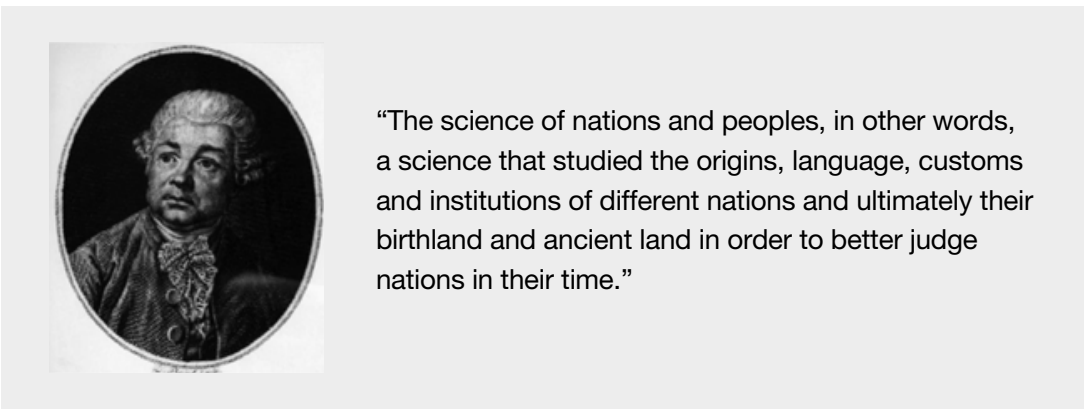

Adam Franciscus Kollarius (1720-1783)

Kollár wanted to study the ethnic distribution of the Hungarian Kingdom freed from Turkish rule from the historical and contemporary perspective of ethnology.

The research material of Kollár's ethnology consisted of dictionaries, the grammars of different languages, and chronicles. His work greatly influenced his contemporaries, such as August Ludwig von Schlözer. ${ }^{16}$

In French-speaking countries, however, the term ethnology became known through the Swiss-French theologist, Alexandre-César Chavannes (1788). ${ }^{17}$ Chavannes wanted to invigorate the science of anthropology; in his interpretation, anthropology should be concerned with the study of our body and spirit alike. Ethnology should be one branch of anthropology, which he considered the science of ethnos, of peoples with their own language and territory (just as did his contemporary, Johann Herder).

\footnotetext{
15 Kollarius, Adam Franciscus 1783: Historiae iurisque publici regni Ungariae amoenitates 1-2. Vienna, Vindobonae. "Notitia gentium populorumque, sive est id doctorum hominum studium, quo in variarum gentium origines, idiomata, mores, atque instituta, ac denique patriam vetustasque sedes eo consilio inquirunt, ut de gentibus populisque sui aevi rectius judicium ferre possint."

16 See Vermeulen, Han F. 1995: Origins and institutionalization of ethnography and ethnology in Europe and the USA, 1771-1845. In: Vermeulen, Han F., Arturo Alvarez Roldan (ed.) 1995: Fieldwork and footnotes: studies in the history of European anthropology. London; New York: Routledge.

17 Chavannes, Alexandre-César 1787: Essai sur l'éducation intellectuelle; Lausanne. Same author: 1788: Anthropologie ou science générale de l'homme; Lausanne.
} 
Since the word anthropology sounded too German in contemporary France, ${ }^{8}$ several other French expressions were used in the nineteenth century (for instance, science de l'homme, science of man) but the word ethnology became the one most widely used by the beginning of the twentieth century. ${ }^{19}$ The choice of an independent name also reflected an intention to distinguish French from German and British anthropology.

By the 1950s, the need for international comparability in the terminology of French ethnology had strengthened. Nowadays, ethnology (which expressed the independence of French cultural research for decades) refers to a subbranch of cultural anthropology in France and in Anglo-Saxon regions that is concerned with the study of ethnic groups still alive, having a separate language. This means that the concept of ethnology has eighteenth-century roots, and its meaning is linked to Kollár and Chavannes.

\section{Sociography, the local anthropology}

The term "sociography" first appears in 1902, in the name of the Sociologie et sociographie musulmane department in Collège de France. Its establishment was initiated by an educated French colonial officer, Alfred Le Chatelier, who was convinced that colonial rule could not be successful without a thorough knowledge of Saharan people. The neologism sociographie was Le Chatelier's idea: he thought that "ethnography" was too German, while "sociology" was intellectual hotchpotch. As Le Chatelier wrote in a letter, his aim with the term sociography was to mock Comte, "whose writings have always irritated me."20

Sociography was thus created as an auxiliary discipline associated with colonialization, but the term gained new meaning in Central Europe. In 1913, the Dutch anthropologist Sébald Rudolf Steinmetz suggested that sociography is a discipline which "carries out the same task in the life of civilized people... as ethnography in the life of so-called savage people." ${ }^{21}$ Steinmetz's ideas inspired the work of an influential figure in German sociology, Ferdinand

\footnotetext{
18 The French considered anthropology to be a German term because of Blumenbach's book on human races; this influential book was published in French in 1804.

19 The first French scientific society concerned with the research of culture was called the Paris Ethnology Society; it operated from 1839 to 1847, and from 1859 was recreated as Société Anthropologique de Paris.

${ }^{20}$ Cited by Sárkány, Mihály 2018: Etnográfia és szociográfia. In: Tóth Pál Péter (szerk.): A magyar szociográfia a 20-21. században. Budapest: Magyarország Felfedezése.

21 Steimetz, Sébald R. 1912-1913: Die Stellung der Soziographie in der Reihe der Geisteswissenschaften. Archiv für Rechts- und Wirtschaftsphilosophie, 492-501.
} 
Tönnies, ${ }^{22}$ who played a great role in making sociography a significant stream of social sciences in Central Europe for a while. The idea that we should explore our own society in the same way as we study distant people was a revelation, even to those researchers who had never visited distant people, and who never even left their narrow surroundings.

Dimitrie Gusti, who received a thorough social science education in Vienna and Berlin, became a central figure in Romanian social sciences between the two world wars. Gusti's "monographic sociology" perfected Steinmetz's idea of "local anthropology": it sought to describe each settlement as a separate entity, based on several possible factors, summarizing the result in one single monograph. It is interesting to note that the members of Gusti's school, especially Henri Stahl, specifically collected quantitative data; they were not influenced by the methodological turn that brought about greater emphasis on qualitative field-work techniques in cultural anthropology.

Central European sociography between the two world wars was especially influenced by right- and left-wing politics. For instance, Czechoslovak sociography of the time was divided into two blocks, based on authors influenced by right-wing and left-wing politics. Accordingly, they had different interests, one studying villages, the other working with workers' sociography, until both were marginalized by the new Communist power in 1948.

Hungary did not offer social sciences education between the two world wars, so sociography was practiced by enthusiastic amateurs with a strong sense of mission: they wanted to reveal to city-dwellers the miserable and hopeless situation of villagers and suburban workers. In 1936, a book series with a telling title was launched: Discover Hungary, which still exists to this day. A unique feature of Hungarian sociography is that it was also practiced by literary writers, so some of this work is of literary value. Another Hungarian characteristic is that the latter achieved greater social and political influence than in other countries: due to the political movement of the so-called country writers, the "third way" seemed like a real alternative for a while in a country that was hesitating between Communist and Nazi regimes.

Visual communication was an important part of the sociographical tradition from the beginning; two expressions reveal this: social documentary photography, and socio-film. The sociographical tradition did not become a part of mainstream, Anglo-Saxon anthropology, and it was also marginalized in Central Europe, as it was politically compromised. Nowadays, sociography is mainly a concept of the past, even though it contains three elements that could be used by contemporary anthropological thinking:

22 Tönnies, Ferdinand 1931: Einführung in die Soziologie Edition Classic. VDM Müller, Saarbrücken 2006, ISBN 978-3-86550-600-9 (Nachdr. d. Ausg. Stuttgart 1931). 
1. Steimetz's warning - namely, that we are surrounded by unknown territory -, seems more useful today than between the two World Wars. In the past, it was enough to travel to a distant place to find something exotic. Today, even faraway places are not necessarily exotic; on the other hand, we may discover unusual phenomena within our narrow environment.

2. Gusti's idea that each settlement is a separate world to be discovered may serve as a useful methodological consideration during anthropological fieldwork and applied regional development.

3. In Hungary, the movement of country writers uniquely combined science and literature in the 1930s: they worked in the field, in villages, but produced literary works. Many of their writings were translated into English, such as People of the Puszta, by Gyula lllyés. Thanks to them, sociography became a movement, and left the ivory tower. The movement's relevant message is that it is not enough to know a phenomenon; you also have to present it in a way that is acceptable to the wider public.

\section{Sociology and anthropology: where do we draw the line?}

The boundaries between sociology and anthropology are just as vague and transparent as those between ethnography and cultural anthropology. The two disciplines are undeniably very similar to each other among the social sciences regarding their subject, theoretical approaches, and methods. Researchers have stepped across these thin boundaries many times during the past 100 years, although there have been cases when they worked on reinforcing them.

The work of the so-called "Chicago school," which operated from the 1920s onwards, for instance, can be seen as violating interdisciplinary borders. Research work at the Department of Sociology of the University of Chicago focused on social problems caused by the modernization of society, industrialization, and urbanization. The city of Chicago itself proved to be an excellent field for such research: its sudden growth brought with it new sociological processes and big changes. Sociologists working there borrowed their methods mainly from anthropology, preferring to employ, for example, participant observation. Thus, their theories moved along the boundaries of sociology and anthropology. Robert Park and Ernest Burgess (1925), in their human-ecological theory, examined social phenomena projected onto urban spatial structures using ethnographic data. ${ }^{23}$

${ }^{23}$ Park, Robert; Ernest W. Burgess; Robert McKenzie (1925): The City. Chicago: UCP. 
The strongest effort to separate the two disciplines is represented by a study by Talcott Parsons and Alfred Kroeber, published in 1958. ${ }^{24}$ Kroeber, a disciple of Franz Boas, was one of the greatest pioneers of the first institutional forms of American anthropology. Parsons was already counted as being among the leading theorists in American sociology, and created his comprehensive theory with reference to Durkheim, Weber, and Pareto. Their declaration in 1958 had been projected in advance by their earlier work. In their joint publication, they declared that it was important to differentiate between social structures and cultural systems, not only on a conceptual but also on a methodological level. This meant separating the two disciplines. According to their stance, sociology is concerned with human society, while anthropology is concerned with culture. However, Kroeber and Parsons did not leave a definition of what "society" or "culture" meant.

\section{Action anthropology (Judit Dobák)}

We are in the 1840s. In a forest near New York, a few middle-class American men, dressed as Indians (with painted body, tomahawk, and headpieces) are singing and dancing. It is the annual meeting of a secret association (the Iroquois League). One of the tasks of the secret association is to teach contemporary American society the important values of Iroquois culture, such as respect for freedom and nature. One of the members is Lewis Henry Morgan, who had strong connections to the Seneca tribe, a tribe of the Iroquois confederacy; as such, he participated in several rites of initiation and even received an Iroquois name: Bridging the Gap. ${ }^{25}$ Morgan collected objects, described the everyday life of the Iroquois, and sometimes even represented them legally. One of his legal innovations was to call the different Iroquois tribes a nation, as this meant protection by international law. Morgan helped the Iroquois Confederacy regain (and partially repurchase) the land that plot speculators coaxed out the hands of tribal chiefs, on which the first Indian reservations were created. ${ }^{26}$

A hundred years later, Sol Tax created the concept of action anthropology. ${ }^{27}$ Tax studied relationship systems among the Meskwaki population (earlier

\footnotetext{
${ }^{24}$ Kroeber, Alfred L.; Talcott Parsons (1958): The Concept of Culture and the Social System. In: American Sociological Review, Vol. 23. No. 5. 1958. 582-583. o.

25 Morgan, Lewis H. 1877: Ancient Society. Charles H. Kerr \& Company, Chicago.

${ }^{26}$ Vörös, Miklós: Tabuk és tanulságok. In: Café Babel. 2010. 65. p. 22-23.

${ }_{27}$ Tax, Sol 1952: Action Anthropology. In: America Indígena 16: p. 103.
} 
termed the Fox tribe), ${ }^{28}$ and after 1948 organized regular student camps on the reservation. Tax and his students were not satisfied with the role of the researcher: they felt that - as highly educated white men - they could not afford to be simple outsiders; they also had to do something for their redskinned compatriots who were denied their past, whose everyday life had been stolen, and whose future was made hopeless. According to Tax, the (action) anthropologist has a moral obligation to help those who they study. However, he also felt that it was important to preserve the freedom of the community: the anthropologist should contribute to understanding the consequences of the different possibilities without becoming a local leader, a local influencer, but only by helping the community find solutions to the problems identified by its members.

Many people dispute that action anthropology has a reason to exist. An important criticism is that action anthropology cannot leave the asymmetrical, patron-client relationship that is created between the researcher and the researched. Often it is the community itself that grants the role of leader/advisor to the researcher, even when the researcher would like to be an equal partner. The researchers cannot step out of their own framework, so their personal, social status determines the relationship between the group and the researcher.

Another group of critiques highlights another characteristic of action anthropology; namely, that it is adapted to fieldwork, not to local requirements. Interventions occur ad hoc when the researcher visits the field (when he has the money, time, and possibility), not when the community is ready for this, or when they need help. Bigger organizations are able to provide longer-term support that is not connected to researchers, but there are very few such organizations and even global-scale ones do not always have the means to make long-term commitments. As a solution, international organizations try to connect their activity to the work of nations.

Critiques of action anthropology in the third group are of an ethical nature. ${ }^{29}$ The results of anthropological research often do not help locals. Related information is written for an audience with contrasting interests, or one disinterested in the needs of the social group in question.

Action anthropologists differentiate their work from that of other anthropological trends - among other things - by declaring that their activities are not based on commissions. This, however, involves a financial challenge: who is going to support non-applied science, and with what aim? A logical answer would be the academic sphere, but we must not forget that the activity

${ }^{28}$ Tax, Sol 2007: The setting of science of man. p.21. In Sol Tax (ed): Horizons of Anthropology. New Brunswick: Aldine 2007. 15-25.

${ }^{29}$ Haraszti, Anna Alkalmazott és akcióantropológia. In: Világosság 2005/7-8. 215-232. 
of action anthropologists often does not satisfy ideas about basic research, ${ }^{30}$ while gaining support and the rhythm of publication is also different from the schedule of academic work. Despite the aforementioned criticisms, the tradition of action anthropology is undoubtedly useful for increasing the social sensitivity of the majority society, especially of university students.

Morgan, the "small-town American lawyer" - as critical literature refers to him - is the archetype of an action anthropologist. ${ }^{31}$ The evaluation of Morgan, and that of action anthropology, changes from period to period, but he undoubtedly fought to protect Iroquois rights and to establish these rights in majority society; on the other hand, he was a man of his time in the sense that he wanted to "civilize" them through education and Christianity in order to integrate them into North American society.

\section{Definitions of Culture}

Cultural anthropology's main field of enquiry is human culture. One of the main (and seemingly, paradoxical) characteristics of anthropology is the fact that there is no consensus regarding the very concept that makes up half the name of the discipline. Alfred Kroeber and Clyde Kluckhohn discussed 164 definitions of culture in 1952;32 the number of such definitions has probably reached a thousand by now. In my opinion, this is not a sign of weakness. Rather, it points to a continuous theoretical and methodological reflexivity, fruitful dispute, the reinterpretation of concepts, and reactions to changing sociological circumstances which have been less marked in, say, economy or ethnography. This chapter presents a selection of different interpretations of the same concept, whilst also drawing attention to shared points as well.

The earliest anthropological definition comes from Edward Burnett Tylor, the founding father of British social anthropology, who in 1871 said: ${ }^{33}$

"Culture... is that complex whole which includes knowledge, belief, art, morals, law, custom, and any other capabilities and habits acquired by man as a member of society."

\footnotetext{
${ }^{30}$ Rubinstein, Robert. A. 2018: Action Anthropology. In: Hilary Callan (ed.) The International Encyclopedia of Anthropology. Hoboken: John Wiley \& Sons Ltd.

${ }_{31}$ Tooker, Elisabeth 1984: Lewis Henry Morgan, the Myth and the man. University of Rochester Library Bulletin. Volume XXXVII.

32 Kroeber, Alfred L.; Clyde Kluckhohn 1952: Culture: a critical review of concepts and definitions. Cambridge, MA: The Museum.

${ }^{33}$ Tylor, Edward Burnett 1871: Primitive Culture.
} 
Adolf Bastian (1884), ${ }^{34}$ regarded as the scholar who established comparative ethnography in Germany, spoke of the general spiritual unity of mankind. His hypothesis was that mankind is one big family of shared origin. According to his theory on elementary or folk ideas (Elementargedanken, Völkergedanken), there are so-called elementary ideas to be found everywhere in the world (today, we would call these cultural patterns) which prove the unity of the genus human. At the same time, so-called folk ideas are also formed as a result of diverse environmental and historical impacts. These ideas, adapted to the given conditions, lead to the development of differences between cultures.

The next important definition (from 1911) comes from Franz Boas (1911), one of Bastian's colleagues and a pioneer of cultural anthropology:

"Culture may be defined as the totality of the mental and physical reactions and activities that characterize the behavior of the individuals composing a social group collectively and individually in relation to their natural environment, to other groups, to members of the group itself and of each individual to himself. It also includes the products of these activities and their role in the life of the groups. The mere enumeration of these various aspects of life, however, does not constitute culture. It is more, for its elements are not independent; they have a structure." ${ }_{35}$

Margaret Mead (a disciple of Boas') provides the following definition (1937):36

"Culture means the whole complexity of traditional behavior which has been developed by the human race and is successively learned by each generation. A culture is less precise. It can mean the forms of traditional behavior which are characteristics of a given society, or of a group of societies, or of a certain race, or of a certain area, or of a certain period of time."

A developer of the structuralist-functionalist school, Bronisław Malinowski (1939), described the essence of culture in the following words: ${ }^{37}$

${ }^{34}$ Bastian, Adolf 1884: Allgemeine Grundzüge der Ethnologie. Berlin. Bastian, Adolf 1902: Die Lehre vom Denken zur Ergänzung der Naturwissenschaftlichen Psychologie, für Überleitung auf die Geistewissenschaften. Berlin.

${ }^{35}$ Boas, Franz 1911: The Mind of Primitive Man. New York: The Macmillan Company.

${ }^{36}$ Mead, Margaret 1937: Cooperation and competition among primitive peoples. New York: McGraw-Hill Book Company.

${ }^{37}$ Malinowski, Bronisław 1939: The Functional Theory. In: Malinowski, Bronisław 1944: A Scientific Theory of Culture and Other Essays. Chapel Hill: The University of North Carolina Press, 145-176. 
"Culture is essentially an instrumental apparatus by which man is put in a position to better cope with the concrete, specific problems that face him in his environment, in the course of the satisfaction of his needs. It is a system of objects, activities, and attitudes in which every part exists as a means to an end [...] in which the various elements are interdependent."

The famous representative of structuralist anthropology, Claude LéviStrauss, elaborated on the relationship between culture and language at a conference in 1953: 38

"The relationship between language and culture is an exceedingly complicated one. Firstly, language can be said to be a result of culture: The language which is spoken by one population is a reflection of the total culture of the population. But one can also say that language is a part of culture. It is one of the many things which make up a culture [...] Thirdly, language can be said to be a condition of culture, and this in two different ways: Firstly it is a condition of culture in a diachronic way, because it is mostly through the language that we learn about our own culture ... But also, from a much more theoretical point of view, language can be said to be a condition of culture because the material from which language is built is of the same type of material out of which the whole culture is built. Language, from this point of view, may appear to lay a kind of foundation for the more complex structures which correspond to the different aspects of our culture."

Cognitive anthropology's concept of culture was influenced both by theories of linguistics and cognitive psychology, which became increasingly dominant in the second half of the twentieth century: ${ }^{39}$

“...culture is an idealized cognitive system - a system of knowledge, beliefs, and values - that exists in the minds of members of society. Culture is the mental equipment that society members use in orienting, transacting, discussing, defining, categorizing, and interpreting actual social behavior in their society."

38 Lévi-Strauss, Claude 1953: Linguistics and Anthropology. Supplement to the International Journal of American Linguistics, 19/2. Lévi-Strauss, Claude 2001 (1953): "Linguistics and Anthropology." In: Lévi-Strauss, Claude 2001 (1973): Structural Anthropology. New York: Basic Books. Transl. Claire Jacobson and Brooke Grundfest Schoepf.

39 Casson, Ronald W. 1999: Cognitive Anthropology. In: Wilson, Robert A.; Frank C. Keil (eds.) 1999: The MIT encyclopedia of the cognitive sciences. Cambridge, MA: MIT Press, 120-122. 
In the 1960s-1970s, Marvin Harris revived nineteenth-century theories of evolution. His book on cultural materialism propagated by him, written in 1979, reflects this: ${ }^{40}$

There is nothing hypothetical or mysterious about culture. It did not come into existence through some sudden abrupt reorganization of the human mind; rather, it emerged as a byproduct of the evolution of complex neural circuitry, and it exists in rudimentary form among many vertebrate species.

Exploring cultures, Clifford Geertz emphasized the importance of understanding what symbols mean. His definition from $1973^{41}$ articulates the following:

"The concept of culture I espouse, and whose utility the essays below attempt to demonstrate, is essentially a semiotic one. Believing, with Max Weber, that man is an animal suspended in webs of significance he himself has spun, I take culture to be those webs, and the analysis of it to be therefore not an experimental science in search of law but an interpretive one in search of meaning [...] Cultural acts, the construction, apprehension, and utilization of symbolic forms, are social events like any other; they are as public as marriage and as observable as agriculture."

The above list of definitions is by no means meant to be exhaustive - that would be impossible. I have merely set out to present the diversity of ways culture has been defined. The subject of anthropological research (culture) is continuously changing and elusive, and so is the way it is perceived.

\footnotetext{
${ }^{40}$ Harris, Marvin 1979: Cultural Materialism: The Struggle for a Science of Culture. New York: Random House.

${ }^{41}$ Geertz, Clifford 1973: The Interpretation of Cultures: Selected Essays. New York: Basic Books.
} 


\section{EVOLUTIONARY ANTHROPOLOGY}

\section{'Progress': The Nineteenth-Century's Faith in Development}

When we hear the word evolution, most of us think of Charles Darwin's theory of evolution. This is not a surprise, since Darwin's theory of evolution is taught with great emphasis in primary and secondary school biology classes, while the influence of his main work, The Origin of Species is presented in our studies of history or even literature.

We learn less about the fact that during his own times, in the middle of the nineteenth century, Darwin's theory was just one possible explanation of the phenomenon called progress, development, or evolution; a phenomenon that many scholars tried to capture in biology and other disciplines.

At the time, people hoped that progress would make the world a better place and would increase the quality of human life. This almost childlike faith in progress is reflected in Jules Verne's still popular novels (which were read by adults in his time) and in different political and artistic forms of expression. The idea of progress was permeated by positivism: the concept that the world may be understood. Faith in progress was universal at the time. Contemporary discussion did not revolve around the existence of development, nor the desirability of progress, but around the things that drive, cause, and maintain continuous development. The first trend in cultural anthropology, often called evolutionary (or evolutionist) anthropology in retrospect, was born in the intellectual atmosphere of debates about evolution.

The idea of progress gave way to several alternative explanations in the second half of the nineteenth century; in this book, we present three of them: the approaches of Herbert Spencer, Lewis Henry Morgan, and Felix Somló. Of course, the brief introduction of the thoughts of these three authors does not provide a full picture of the evolutionary ideas of the nineteenth century - it can only venture to give a sense of the enormous differences between such 'evolutionary' concepts that may seem unified when looked at from a distance. 


\section{Herbert Spencer's theory of evolution: from homogeneous to heterogeneous}

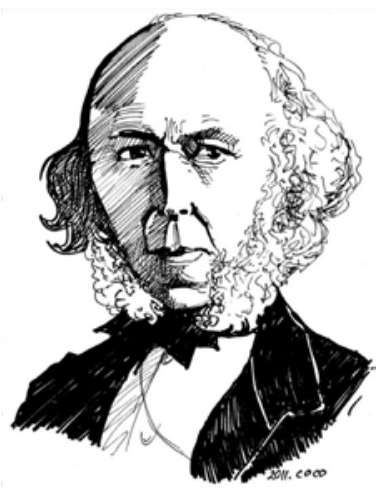

Herbert Spencer

(1820-1903)
The younger son of a family of British Protestant teachers, Herbert Spencer was supported from a very young age by an uncle living in the country, Thomas Spencer. He did not finish his university studies, and at the age of 22 started working for a railway company, which continued for a few years. At a very young age, he also started to write significant articles for contemporary radical journals, such as The Nonconformists. His Social Statics, published when he was 31, was an important success. The book promoted individual rights on the basis of Jean Lamarck's theory of evolution, which is why, a few decades later, Spencer's work came to be regarded by many as a precursor of anarchism.

In 1853, upon the death of his uncle, Spencer inherited some assets, thanks to which he was able to leave his job as the editor of the Economist and move to the country to live a solitary, yet - in his eyes - privileged life of an independent scholar. He became a member of several important scientific societies of the time, and through these he got to know Charles Darwin. His work could fill a small library, but his most important book is the multiplevolume $A$ System of Synthetic Philosophy, the first volume of which, First Principles, was published in 1862.

The extracts below were published in Hungarian in 1919; the short publication contains the main thoughts of First Principles formulated by the author in a shortened version for a journal. ${ }^{43}$ The following texts demonstrate that Spencer has an entirely different approach to progress than the one Darwin adopted in relation to species: the concepts of mutation and selection do not appear here; the main explanatory principle is the transition from homogeneous to heterogeneous.

The history of every plant and every animal, while it is a history of increasing bulk, is also a history of simultaneously-increasing differences among the parts. (...) One of the Arthropoda, for instance, has limbs that were originally indistinguishable from

${ }^{43}$ Spencer, Herbert (1937). First Principles (Sixth and Final Edition). London: Watts \& Co. pp 298-307. Full text: https://archive.org/details/firstprinciples035476mbp 
one-another, composed a homogeneous series; but by continuous divergences there have arisen among them unlikenesses of size and form, such as we see in the crab and the lobster. Vertebrate creatures equally exemplify this truth. The wings and legs of a bird are of similar shapes when they bud-out from the sides of the embryo. (...) All germs are at first spheres and all limbs are at first buds or mere rounded lumps. From this primordial uniformity and simplicity, there take place divergences, both of the wholes and of the leading parts, towards multiformity of contour and towards complexity of contour. Remove the compactly-folded young leaves that terminate every shoot, and the nucleus is found to be a central knob bearing lateral knobs, one of which may grow into either a leaf, a sepal, a petal, a stamen, or a carpel : all these eventually-unlike parts being at first alike. The shoots themselves also depart from their primitive unity of form; and while each branch becomes more or less different from the rest, the whole exposed part of the plant becomes different from the imbedded part. So, too, is it with the organs of animals.

According to Spencer, evolution - the transition of things from homogeneous to heterogeneous - is a universal phenomenon that may also be observed in physics, chemistry, and biology.

(...) It has been shown by Wolff and Von Baer, that during its development each organism passes from a state of homogeneity to a state of heterogeneity. For a generation this truth has been accepted by biologists.

(...) Hence we may say that (...) our knowledge of past life upon the Earth (...) support(s) the belief that there has been an evolution of the simple into the complex alike in individual forms and in the aggregate of forms.

Spencer stresses that human individuals and humanity are constantly developing, and this development is driven by the same forces as natural phenomena are:

The advance from the homogeneous to the heterogeneous is clearly displayed in the progress of the latest and most heterogeneous creature Man. While the peopling of the Earth has been going on, the human organism has grown more heterogeneous among the civilized divisions of the species; and the species, as a whole, has been made more heterogeneous by the multiplication of races and the differentiation of them from one another. In proof of the first of these statements may be cited the fact that, in the relative development of the limbs, civilized men depart more widely from the general type of the placental mammalia, than do the lowest men. (...) If further elucidation be needed, every nursery furnishes it. In the infant European we see sundry resemblances to the lower human races; as in the flatness of the alae of the nose, the depression of its bridge, the divergence and forward opening of the 
nostrils, the form of the lips, the absence of a frontal sinus, the width between the eyes, the smallness of the legs. Now as the developmental process by which these traits are turned into those of the adult European, is a continuation of that change from the homogeneous to the heterogeneous displayed during the previous evolution of the embryo; it follows that the parallel developmental process by which the like traits of the barbarous races have been turned into those of the civilized races, has also been a continuation of the change from the homogeneous to the heterogeneous.

Spencer extends the concept of the transition from homogeneous to heterogeneous to the evolution of human culture and society:

On passing from Humanity under its individual form to Humanity as socially embodied, we find the general law still more variously exemplified. The change from the homogeneous to the heterogeneous is displayed equally in the progress of civilization as a whole, and in the progress of every tribe or nation; and it is still going on with increasing rapidity.

Society in its first and lowest stage is a homogeneous assemblage of individuals having like powers and like functions: the only marked difference of function being that which accompanies difference of sex. Every man is warrior, hunter, fisherman, tool-maker, builder; every woman performs the same drudgeries; every family is selfsufficing, and, save for purposes of companionship, aggression, and defence, might as well live apart from the rest. Very early, however, in the course of social evolution, we find an incipient differentiation between the governing and the governed. Some kind of chieftainship soon arises after the advance from the state of separate wandering families to that of a nomadic tribe. The authority of the strongest and cunningest makes itself felt among savages, as in a herd of animals or a posse of schoolboys: especially in war.

Spencer was an important thinker concerning social progress and development (social evolution). Posterity often (mistakenly) calls Spencer a 'social Darwinist'; however, this is not a valid claim, because even though he believed in social progress, he did not explain it on the basis of Darwinian theories on the contrary, his theory made him Darwin's rival. Spencer $(1864,1884)$ suggested the term 'survival of the fittest,' instead of Darwin's 'natural selection,' and he indeed believed that the expression could be applied to the development of human societies. ${ }^{44}$

44 Spencer, Herbert 1864: Principles of Biology. London: Williams and Norgate; Spencer, Herbert 1884: The Man versus the State. London: Williams and Norgate. 


\section{Lewis Henry Morgan: the steps of the development of culture}

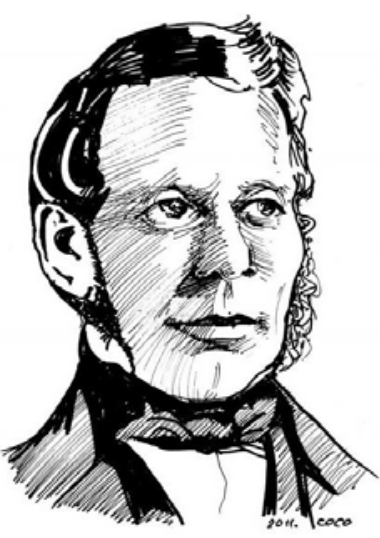

Lewis Henry Morgan (1818-1881)
Lewis Henry Morgan was born into a family of American Protestant farmers in the state of New York, and returned to his homeland after completing his law studies: he lived and worked in the small towns of Rochester and Aurora. He had an outstanding scientific and public career: he was the senator of the state of New York, and the president of an American scientific association (although at that time being an American researcher did not mean much more than belonging to the scientific life of a rural country, from which it was difficult to move into the front lines of science).

From the perspective of the history of science, and more precisely of research ethics, Morgan was way ahead of his time, and lived and worked in a way much more in line with our current concepts of doing cultural anthropology than with the expectations of his contemporaries. At the time, researchers hardly ever visited the 'field' to personally gather information about the communities they were studying, as the prominent cultural researchers of the era never left their desks. Morgan, however spent a lot of time with the Seneca tribe of the Iroquois community of tribes, went through several initiation rituals, and received an Iroquois name (Tayadaowuhkuh - Bridgemaker), becoming a full member of the tribe. In a 'postmodern' way (more than 150 years before the invention of postmodern anthropology), he wanted his own (urban, white) community to learn the values he had experienced among the Iroquois, such as social sensibility, love of freedom, and being close to nature, so he co-founded a club called the 'Grand Order of the Iroquois.' As a lawyer, he defended the Iroquois in several trials: this behavior - the protection of interests - was only formulated as an expectation at the beginning of the 1930s by the first action anthropologists ${ }^{45}$ in Chicago.

Morgan's reports on the Iroquois - his most important works are: The League of the Ho-de-no-sau-nee or Iroquois (1851); Systems of Consanguinity and Affinity (1871); Houses and House-lives of the American Aborigines (1881)

${ }^{45}$ See 'Action Anthropology,' Chapter 5. 
- were interpreted from different angles in the Old World; for instance, Karl Marx's vision of 'primitive communism' was primarily based on Morgan's research. (On the other hand, the respected British and French researchers of the era rarely cited Morgan.)

We can clearly see now that Morgan approached the Iroquois and all nonEuropean peoples with an unprecedented sense of justice and Humanism. Despite this, he was a true child of his time in the sense that he could not imagine the Iroquois (or other 'primitive' peoples) having a culture equivalent to his own. Just like his contemporaries, he had a firm and unquestionable faith in the technical and social progress of his era.

In the creation of his scientific theory, Morgan sought to outline the path and the degrees of the development of humanity. He put forward a complex system of factors for dividing the development of humanity into periods:

The facts indicate the gradual formation and subsequent development of certain ideas, passions, and aspirations. Those which hold the most prominent positions may be generalized as growths of the particular ideas with which they severally stand connected. Apart from inventions and discoveries they are the following:
I. Subsistence
V. Religion
II. Government
VI. House Life and Architecture
III. Language
VII. Property
IV. The Family
[...]

The terms 'Stone Age', 'Bronze Age' and 'Iron Age', introduced by Danish archaeologists, ${ }^{46}$ have been extremely useful for certain purposes ... but the progress of knowledge has rendered other and different sub- divisions necessary. [...]

It is probable that the successive arts of subsistence which arose at long intervals will ultimately... afford the most satisfactory bases for these divisions... With our present knowledge the main result, can be attained by selecting such other inventions or discoveries as will afford sufficient tests of progress to characterize the commencement of successive ethnical periods. ${ }^{47}$

\footnotetext{
46 In the middle of the nineteenth century, scientific work did not pay much attention to the system of references we are now used to, so no wonder that Morgan did not refer to the 'Danish archeologists.' Christian Jürgensen Thomsen (1788-1865), while organizing the material of the Danish national Museum, suggested the division Stone-Bronze-Iron (his main works are: Ledetraad til Nordisk Oldkyndighed, Kjöbenhaven [1836]; Leitfaden zur Nordischen Alterthumskunde, Kopenhagen [1837]). This prompted Jens J. A. Worsaae to prove Thomsen's theory with excavations, and Paul Reinecke to subdivide Denmark's Bronze Age into periods A to E; these periods are still used in European archeology.

${ }^{47}$ Morgan, Lewis Henry 1877: Ancient Society. London: MacMillan \& Company.
} 
Morgan divides the development of humanity into three great phases, the period of savagery, that of barbarism, and the final one of civilization, all subdivided into three parts: lower, middle, and upper status. The table below shows the social and technical achievements necessary to 'reach' each status:

Simplified model of Morgan's theory of evolution:

\begin{tabular}{|l|l|l|l|}
\hline Periods & Status & $\begin{array}{l}\text { Most important } \\
\text { civilizational } \\
\text { achievements }\end{array}$ & $\begin{array}{l}\text { Peoples living at } \\
\text { the given status }\end{array}$ \\
\hline Savagery & Lower & None & None $^{*}$ \\
\hline & Middle & $\begin{array}{l}\text { Fire, fishing, } \\
\text { articulate speech }\end{array}$ & $\begin{array}{l}\text { Peoples of } \\
\text { Australia, Papuans }\end{array}$ \\
\hline Barbarism & Upper & Bow and arrow & $\begin{array}{l}\text { Athabasca tribes, } \\
\text { Columbia Valley }\end{array}$ \\
\hline & Middle & Pottery & $\begin{array}{l}\text { Tribes living in the } \\
\text { East of Missouri }\end{array}$ \\
\hline & Upper & $\begin{array}{l}\text { Eastern hemisphere: } \\
\text { domestication of } \\
\text { animals } \\
\text { Western hemisphere: } \\
\text { maize, squash }\end{array}$ & $\begin{array}{l}\text { Old Britons, } \\
\text { empire building } \\
\text { peoples of ancient } \\
\text { Mexico and Peru }\end{array}$ \\
\hline Civilization & $\begin{array}{l}\text { Ancient and } \\
\text { modern periods }\end{array}$ & $\begin{array}{l}\text { Phonetic alphabet, } \\
\text { works of literature }\end{array}$ & $\begin{array}{l}\text { Still exists } \\
\text { Germerian era, } \\
\text { Caesar's time }\end{array}$ \\
\hline
\end{tabular}

* 'Lower Status of Savagery: This period commenced with the infancy of the human race, and may be said to have ended with the acquisition of a fish subsistence and of a knowledge of the use of fire. Mankind were then living in their original restricted habitat and subsisting upon fruits and nuts. The commencement of articulate speech belongs to this period. No exemplification of tribes of mankind in this condition remained to the historical period.' Morgan, Lewis Henry 1877: Ancient Society. London: MacMillan \& Company, Chapter 1.

Naturally, this simplified table does not contain all the elements that led Morgan to position a given culture one step ahead of another, but it still shows his aim: he believed that human cultures may be located hierarchically. His goal was to replace the one-sided categories of Danish archeologists - based only on the materials that people used - with a more complex systems of elements, thereby developing the linear evolutionary perspective into a system comprising all the cultures of the 
world. In his eyes, all cultures - wherever and whenever they developed on Earth must go through the same civilizational steps to arrive at the most advanced level - the level represented by the author's own culture, among others.

These days, it is easy to see that the theory of linear evolution is far from perfect. The table shows, for instance, that Morgan considers the use of a phonetic alphabet to be an important milestone, so all those peoples who used logographic writing, syllabary, or hieroglyphic writing - in Morgan's view - could only attain the different statuses of barbarism. This is a rather anachronistic suggestion, considering that both Japanese and Chinese culture - among others -became leading industrial and political powers in the world economy with their logographic writing.

Morgan, however, was a true son of his time. He did not consider societies that permitted polygamy or did not use modern machines to be equivalent to his own. Distant societies located further away did not attain the status of civilization in his eyes.

Contradictorily, he allowed for an 'exception' in his linear system of evolution: ancient American cultures could reach the middle status of barbarism without the domestication of animals. In permitting this, he tried to avoid a contradiction: he did not want the empire-building Incas or the builders of the Mayan archeological cities discovered in the $1840 \mathrm{~s}^{48}$ to be confined to a humiliatingly low, lower barbarian status.

That is why, in his linear theory of evolution, different abilities were required to reach the middle status of barbarism in the Old and New Worlds; in his system, the production of maize as a cultivated plant was equivalent to the domestication of animals.

In Morgan's age, the expressions savagery, barbarism, and civilization spoke for themselves. Contemporary anthropology does not use these expressions anymore, as they partially undervalue, and partially (in the case of civilization) overvalue, the status of the given people. The undesirability of the expressions 'savage' and 'barbarian' in modern scientific life hopefully does not require explanation, although the word 'civilization,' however, is still used by some disciplines, so it is worthwhile explaining why its use is not recommended to scholars of human cultures.

The root of the word civilization is the Latin 'civitas'(city). A 'civilization' may thus be translated as a culture that creates a state or builds a city. This could give credence to the old concept that city builders represent a higher-order culture than that of uncivilized (such as hunter-gatherer or nomadizing) peoples.

48 The book Incidents of Travel in Yucatan by John Lloyd Stephens (explorer) and Frederick Catherwood (graphic) was the first to report on the Mayan archeological cities, and was published in the United States in 1843. 


\section{Civilization - The Game of the One and Only Road}

\section{By Zsuzsa Winkler}

Nowadays, we usually do not agree with Lewis Henry Morgan's views - that development proceeds in only one direction, and that different civilizations may be located on the ascending steps of development, although the concept of linear evolution may still be found in popular books and other works. A good example of this is the computer game called Civilization*.

When the game begins, we must choose an ethnic group: we may be Roman, American, Zulu, Babylonian, etc. There are two ways of winning the game: either by destroying all our enemies, or by building a spaceship that takes us to Alfa Centauri where we find a new colony of humans. In both cases, we have to ascend the steps of development by inventing different civilizational achievements. If we fall behind in our development, other peoples kill us.

During the game, development is linear. Without the invention of monotheism, for instance, our progress freezes and our culture goes extinct. The logic of the game dictates that monotheism is beneficial for all peoples (Zulus, Greeks, Russians). We observe the same phenomenon in the case of the bow and arrow, pottery, the alphabet and money just like in Lewis Henry Morgan's system. We must proceed through all the steps of development during the game to become the most developed and to win.

In the more advanced versions of Civilization, the linear principle of development of the first, 1991 version has been slightly modified. Now, we can also win by being culturally superior (without destroying others), and the developers of the game have demonstrated a degree of flexibility with regard to the compulsory steps of development. A civilization may 'skip' democracy or monotheism, for instance, although most civilizational achievements are still built upon each other, however - just like in the model imagined by Morgan.

The game of 'Civilization' thus has a contradictory effect on society. On one hand, it may draw players' attention to historical issues, while on the other hand, many adolescents may start to wonder whether all modern cultures are equal or some are more developed than others.

* Sid Meier's Civilization 1991: MicroProse Software, Inc. 


\section{Felix Somló's 'sociology' textbook from 1901}

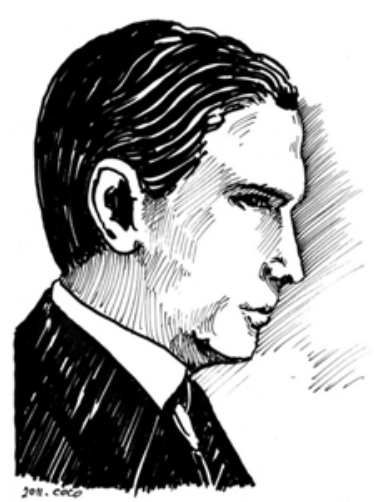

Felix Somló (1873-1920)

Felix Somló (in his international publications, he used the name Felix Somlo) came from a family of Jewish bankers in Bratislava; his parents wanted him to pursue a financial career but he defied these expectations and turned his back on financial studies. He worked for the Hungarian Railway Company, then studied law in Cluj, Leipzig, and Heidelberg. Even though he had no secure living (he was a university professor in Cluj, Oradea, and Budapest), his unique scientific approach makes him a pioneering figure in Hungarian ethnography and the philosophy of law; we will return to his work in later chapters of this book as well. He was a co-founder of the Society of Social Sciences but did not agree with the so-called 'radicals.'Felix Somló is held in high esteem in the fields of Hungarian philosophy, law, ethnography, and cultural anthropology. This 'interdisciplinarity' seems strange now, but at the beginning of the twentieth century there were no distinct lines between the different fields of social sciences. Just like his contemporaries - such as Ágost Pulszky and Gyula Pinkler -, Somló thought that the basis of the philosophy of law was 'sociology,' by which he meant social sciences in general. That is why the first textbook in Hungarian entitled Sociology - the contents of which would make it an anthropology textbook today - was written by a man who studied law.

The extracts below are from his aforementioned book Sociology, which outline the 'evolution' of an institution considered fundamental in society namely, marriage. .9

\section{Buying women}

The custom of kidnapping women [...] is more or less forgotten. In most uncivilized groups, the husband must provide a fee for his bride. Kidnapping women was followed by buying women. The simplest way of buying a woman is to offer another woman to replace the wife. It is much more common, however, to earn the woman by doing services for her family. The man spends some time with the woman's family and does servant work. We know this custom from the Jewish tradition, but it is very common

49 The source of the citations: Bódog Somló 1911: Szociológia (Sociology). Second edition. (First edition: 1901). Budapest: Stampfel. 
among the uncivilized species of America, Africa and Asia. [...] He often had to serve the time agreed before marrying the girl, while in other places he could have her in advance.

Buying women as a way of sealing a marriage is not only a habit of modern peoples of low culture, it used to flourish among the ancestors of educated peoples. Women were bought in ancient Peru and Mexico, Japan and China, among the ancestors of the Finns and in the earlier phases of Aryan people. The Hindus, the Germanic tribes, the Romans and the Greeks all married by buying women. Hungarian language also proves that our ancestors used to buy women (bridegroom = völegény = young man who buys, bride = eladó leány = girl for sale). [...]

The transition probably took place in the following way: the primary form was kidnapping against the parents' wishes; this was later completed by offering compensation to avoid revenge and this practice developed into the advance offering of gifts.

\section{The rituals of marriage}

The caveman's marriage lacked ceremoniousness and several uncivilized peoples still keep this tradition. The ceremonies connected to marriage only appeared later through different ways. [...] As soon as the importance of marriage is recognized, its start is celebrated just like other important events in human life. The wedding feast is a universal custom, accompanied by different marriage customs and ceremonies. [...] Groups at a higher status of civilization almost always use religious ceremonies, such as the ancient Mexicans, the Hindus, the Egyptians, the Jews, the ancient Greeks. Roman confarreatio also has a long history but lost its significance during the age of the emperors. Christianity rendered marriage its religious nature. [...] The dogma of the sacredness of marriage had already been developed in the 12th century, marriage, however, had been considered valid without the blessing of the Church until 1563 when the Council of Trent decided that the blessing of the Church was an important part of the ceremony. [...] Luther's view - that marriage concerns the state instead of the Church - was not shared by the legislative bodies of Protestant countries, so the blessing of the Church remained a significant part of weddings. This concept was first challenged by the French revolution. The 1791 French Constitution declared that in the eyes of law, marriage is just a civil contract; since then, civil marriage has been a practice in most European countries.

\section{Monogamy, polygamy, polyandry}

Most low species of animals are instinctively monogamous or polygamous. Humans have several forms of marriage. We see one man's marriage with one woman (monogamy), one man's marriage with several women (polygamy), several men's marriage with one woman (polyandry) and in some exceptional cases, several men's marriage with several women.

Polygamy was allowed in most ancient, historic societies, and may still be observed in several civilized and most savage tribes. Nevertheless, there are many primitive 
peoples that forbid polygamy or make it a privilege of chiefs. But even where polygamy is allowed, it is much less universal than we tend to believe. Polygamy is almost always restricted to a fraction of the population, the majority being monogamous. [...] Polyandry is much less frequent than polygamy. And while polygamy is usually a consequence of richness and only occurs in the relatively rare cases where the man can afford to get and keep several wives, polyandry - apart from a few other rare reasons - is mostly a consequence of poverty; in such cases it would be more precise to say that several men - who cannot afford to keep separate wives - share one wife. The husbands are very often relatives, usually brothers. Polyandry also has versions that approach monogamy. In these cases, we usually find a superior husband and several replacements who only exercise husband's rights in the absence of the first husband, in all other instances they are in his service. Thus, monogamy is the dominant form of marriage; other forms are exceptional and even if they occur, they are modified towards monogamy.

As this short extract demonstrates, Felix Somló shares the concept of linear evolution. He sees the development of humanity as heading in one single direction, and in the example presented in the extract, the case of marriage, the peak of development is a monogamous and secularized civil marriage.

\section{The evolutionary 'pyramid'}

The linear perspective of evolution imagines development as a process which occurs as time moves forward: the later the era, the more advanced the given culture. According to this view, if we look back in time, we find a lot of (a seemingly infinite number of) undeveloped cultures that have now disappeared, whereas there are very few cultures that were as 'highly educated' as we are today, and may thus be located at the peak of the pyramid of development.

This perspective implicitly limits the group of 'developed cultures.' The nations used to illustrate this theory - the great European nations and their North-American relatives - are considered the most developed cultures. The followers of the evolutionary perspective believe, however, that developed nations only occupy a relatively small part of the globe, and the further we move away from these parts, the more barbarian peoples we meet. According to this concept, continental Europe is far behind Great Britain (as far as reading and writing and the proportion of educated people are concerned), while Asia lags behind Europe but is still more educated than Africa.

The lowest part of the evolutionary pyramid was occupied by a few groups, such as the inhabitants of Patagonia (systematically killed later on), Inuits, Pygmies (who were also displayed in zoos), Khoisan (who were used 
in medical experiments) and the inhabitants of the Tasman Island whose last survivor was displayed in pieces in a museum of natural sciences until 1997. (For details about the genocide in Patagonia and humans in zoos, see the boxed texts in the following material).

When people of different cultures were displayed in circuses or museums, the public was not outraged because the latter were not considered equal to more developed nations. A feeling of superiority and scorn for indigenous people was not always conscious: it was part of the spirit of the era; of everyday life, as is visible in the novels of P. Howard, in contemporary travel reports, jokes, and anecdotes.

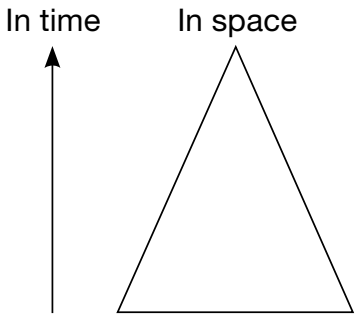

Evolutionary pyramid: development in time and space

People in zoos

The anthropologist William John McGee wanted to display the whole scale of human types and cultural evolution during the 1904 World Expo in St. Louis. Thus Ota Benga, a Pygmy from Congo, was purchased from the Belgian colonial army by an expedition commissioned by McGee. The Pygmy was a successful sight at the exhibition. Since he was not able to readjust to his new environment, the man in charge of him moved him to the Bronx zoo. He remained one of the main features of the zoo until his death; he was displayed near the monkey house due to scientific considerations.

At the time, humans were not only exhibited in zoos in the United States; around the turn of the century, similar exhibitions were also organized in European cities - among others, in the Budapest zoo.

According to Hanga (2003), the first such exhibition was organized by accident: due to a logistical problem, there was nobody to transport reindeer from Lapland to a zoo, so a merchant asked the Lapps to 
accompany them. 'And - once they get to the road - they should bring theirtents and utensils, so that the public of European cities, always hungry for exotic things, may see them!'Hanga says that the exhibition was a great success. So much so that the population of Frankfurt, Hamburg, Vienna, and Budapest soon had the opportunity to meet a group of people from Tierra del Fuego, some Nubians, Eskimos, Somalians, Kalmyks and natives of Ceylon, all organized by Hagenbeck, of course. As a contemporary articles reports: 'these groups brought their animals, tents and utensils, and town after town showed their original customs, skillfulness, dances, fights and feasts, in short: their everyday life.'

* Zoltán Hanga 2003: Állatkerti emberbemutató (Humans exhibited in zoos). In: Vadon, 2003/2, 20-21.

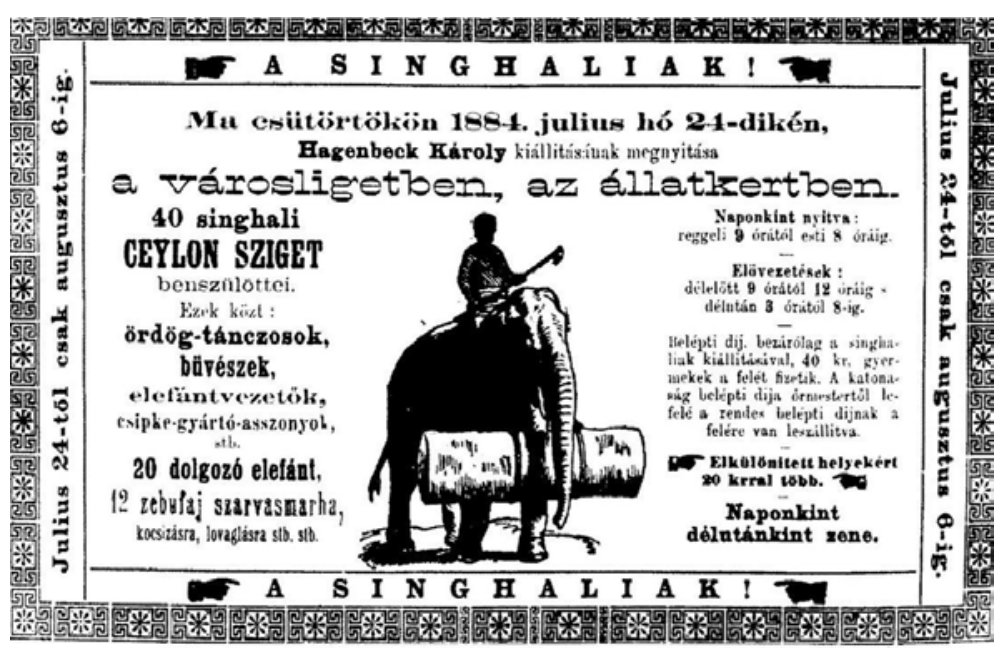


Szeljak (2012)* highlights that 'while millions were entertained by watching these shows, between 1800 and 1958 more than 35,000 natives were taken from their homeland by force or with false promises, to be stared at and exploited in different cities of the world.' Although the exhibitions were supposed to serve scientific and educational purposes, the public viewed them as exotic spectacles at best.

'The 250 Negroes who came to Budapest from Africa for the Millennium celebrations are indeed an interesting sight at the zoo' - reports an August 1896 issue of Vasárnapi Újság (Sunday Journal) (quoted by Szeljak, idem). 'It is a tame, peace-loving race; and their habitats are excellently organized. So many savages and no bad smells! This is really astonishing. They do not lack anything; they are well fed and content: and to our greatest surprise, they do not beg! On the contrary, their manners are excellent. They are not reserved towards the public; they smile and willingly talk to them; some even speak English.'

The representatives of different cultures not only appeared at exhibitions, they were also parts of circus performances.

On June 15, 1876 Dakota warriors, among them chief Sitting Bull (Tatanka Yotanka), achieved the greatest Indian victory of all time over the American army - more precisely, over the 7th cavalry, led by George A. Custer. Following the defeat at Wounded Knee, Tatanka Yotanka led his army - amidst continuous fighting - to Canada, where they lived until 1881. The heroic deeds of the Indian chief made him a symbol of liberty all over the world. On July 20, 1881 he returned to the land of his birth, and surrendered at Fort Bufford to the American army. Since he suspected that he would be trapped in the reservation, he accepted Buffalo Bill's offer to entertain the public as an actor in the famous Wild West Show: he played himself in several reenacted scenes. With the travelling circus, he also visited European cities. (When he later returned to his people in the reservation, he was soon shot to death during a police arrest.)

* Cited by György Szeljak 2012: Emberek az állatkerti kifutón (People in the Zoo). Magyar Múzeumok, 31 March 2012. magyarmuzeumok.hu 


\section{What was Evolutionary Anthropology Like?}

Anthropology based on the evolutionist perspective was the earliest and longest valid cultural research trend: if we trace the beginning to 1871, the publication of Edward Tylor's Primitive Culture, we may ascertain that nobody doubted the validity of the teachings of this school for about half a century. In spite of all this, several characteristics of this trend seem anachronistic today. This section will describe some of these elements.

\section{Armchair anthropologists}

According to a well-known (but never actually proven) anecdote, somebody asked James Frazer, the writer of The Golden Bough, whether he had ever met one of the 'savages' he describes in his books. 'God forbid!' - replied Frazer. In Great Britain and the United States, the need for field work only appeared in the 1920s (but much earlier in Eastern European ethnography).

The anthropologists of the nineteenth century are nicknamed armchair anthropologists by posterity, and with good reason. The scientists of the era would not have considered this an insult: most of them believed that their mission was to catalogue and interpret the thousands of reports coming in from the field. For instance, Felix Somló used more than ten thousand research summaries and reports to write his work on the system of exchanges of ancient societies. ${ }^{50}$ This remarkable achievement does not even come near that of James Frazer's, who made several hundred thousand catalogue slips for the different volumes of The Golden Bough. The need for field work - for the researcher to gain personal experience of the studied culture - only appeared in the 1920s in Great Britain and the United States.

\section{The race to 'discover' 'primitive' cultural traits}

The cultural researchers of the nineteenth century not only believed in the existence of a kind of evolutional pyramid; they were also convinced that older cultural traits were rarer and more difficult to find (and thus more valuable) than new ones. This approach determined the work of both archeologists (who wanted to discover as many ancient findings as possible) and anthropologists,

50 Somló Felix 1909: Der Güterverkehr in der Urgesellschaft. Bruxelles-Leipzig: Misch and Thron. 
who tried to describe the most ancient cultural traits possible when reporting on the societies they studied.

The Latin equivalent of the English word 'ancient' is 'primitive.' In some Neolatin languages, the word 'primitive' still does not have negative connotations, but educated people who use English, French, or German do not use this expression since evolutional anthropology has added to it an ethnocentric interpretation, thereby promoting the superiority of Western civilization.

The race to discover primitive cultures encouraged some people to use unfair methods. In the 1970s, the press wrote frequently about the Tasaday tribe in the Philippines; among other publications, National Geographic ran several articles on the story and several documentaries were made. According to reports, the latter tribe had lived in isolation since the Stone Age in the caves of the island of Mindanao. The Philippine government had been trying to protect the 'last tribe' since their discovery. Journalists, researchers and other visitors could only contact members of the tribe under serious restrictions. President Ferdinand Marcos, the dictator of the Philippines, declared the area around the caves as under protection in 1972, and then in 1976 completely closed it to visits. In 1986, after the fall of Marcos, the isolated tribe was found to be an intentional fraud. Their members only lived in 'Stone Age' settings during their displays. In reality, although they did preserve some elements of their hunter-gatherer lifestyle, they regularly traded goods with the population of surrounding villages, so they had clothes, metal tools, and even cigarettes.

\section{Ethnocentrism}

The expression ethnocentrism means that we interpret different cultures in comparison to our own, and using our own worldview. Ethnocentrism is a natural consequence of linear evolution: if we accept the existence of development and of progress heading in a certain direction, then we must also suppose that there is a culture that may be considered the 'most advanced.' Representatives of 'developed' civilizations use the cultural achievements of their own as an etalon. In the case of distant cultures, anthropologists have compared their characteristics with 'civilized' standards, values, and norms. Based on the differences from and similarities to their own culture, the studied culture was thus declared 'developed' or 'primitive.'

Ethnocentrism also implied that the researcher considered themselves to be superior (or more precisely: a representative of a more advanced culture) to the studied ethnic group - wherever the former was on the globe.

The ethnocentric vision of the nineteenth century inspired colonization, but it is important to understand that ethnocentrism and exploitation are not the 
same concepts. This difference is like that between egocentrism and egoism. An egotist is a selfish person who wishes that other people would serve their interests. On the other hand, an egocentric one perhaps doesn't wish to exploit other people, but is not empathic enough to recognize the different needs of others. In a similar way, ethnocentrism doesn't value cultural differences.

This feeling of superiority characterizes even prominent researchers such as the otherwise renowned E. E. Evans-Pritchard, the anthropologist whose book on Nuers - now a classic due to its excellence - is cited in our boxed text. EvansPritchard explicitly denied the superiority of the British (or other Europeans) in all his public discourses, and warned against ethnocentrism. The extracts still indicate, however, that - despite this awareness - he could not completely dismiss the spirit of the era that considered the disdain of Black Africans to be natural.

\section{The superior anthropologist}

\section{By Iván Selmeczi}

Sir Edward Evan Evans-Pritchard was an influential figure in British anthropology, and his kinship studies - among others - are an unavoidable part of anthropological studies worldwide. His 1940 book on the Nuer tribe of Africa - The Nuer ${ }^{* 1}$ - is now a classic. Below, we cite extracts that show the anthropologist's point of view, rather than the results of research.

The extracts demonstrate that Evans-Pritchard did not consider the studied ethnic group equal to himself (to Western Europeans). In his writings, he often made explicit or implicit remarks that show he thought the culture and economic and social structure of the Nuer tribe to be simpler, less complete, and less advanced than European civilization.

Evans-Pritchard mentions even in the book introduction that he is about to carry out an extremely difficult, tiring task, as his previous experiences with the Nuers made a friendly relationship inconceivable.

I also knew that a study of the Nuer would be extremely difficult. Their country and character are alike intractable and what little I had previously seen of them convinced me that I would fail to establish friendly relations. (page 9) 
Given the circumstances, he thought it was impossible to carry out a high quality anthropological study. Besides the disadvantageous circumstances, he mentions the simplicity of the social structure of the tribe and of the bareness of their culture.

...the investigation was carried out in adverse circumstances; that Nuer social organization is simple and their culture bare. (page 9)

Evans-Pritchard's behavior questioned his equality with members of the tribe from the first days of his research. When carriers arrived, they set up his tent on a green field, but they refused to dismantle it and set it up again in a shadier place. The anthropologist used an interpreter to try to make the Nuers relocate his tent. Since they were no more willing to please him than the carriers, Evans-Pritchard waited another twelve days for a Nuer to solve the problem with some others. Despite his discomfort, it never occurred to him to relocate the tent himself or at least to actively participate in doing so - he probably felt that this job was 'beneath him' (page 10).

$\mathrm{He}$ uses European standards to describe the richness of Nuers. He thinks that the land of the Nuers does not have any desirable and valuable attributes, unless we consider savageness to be one.

From a European's point of view Nuerland has no favorable qualities, unless its severity be counted as such.... (page 51)

All in all, Evans-Pritchard does not paint a very favorable picture of the Nuers. He mostly characterizes them as rude, rough, impolite, and obstinate natives. However, he admits that if the anthropologist approaches the Nuers kindly and without a sense of superiority, they do not refuse the initiation of friendship. In difficult and dangerous situations they can even be nice and polite.

The Nuer have been rightly described as dour, and they are often gruff and curt to one another and especially to strangers. But if they are approached without a suggestion of superiority they do not decline friendship, and in misfortune and sickness they show themselves kind and gentle. (page 183) 


\section{Applied science}

Cultural anthropology served the purposes of colonization in Great Britain and other colonizing countries. We must keep in mind that the reason for colonization was supposed to be the civilizing of primitive peoples - to spread the achievements of European civilization. We cannot doubt that many people really believed in the mission of European nations, and the citizens of the colonizing countries of the nineteenth century would have been outraged at being called selfish and exploitative. The anthropologist's task during colonization was to get acquainted with the given culture, and to understand what the local inhabitants are like. The discipline also provided a means of putting the native in the service of colonizing powers.

The researchers of colonizing countries thus had financial resources and power - this was manifested in the support for expeditions, and the cooperation of colonial officers, among many other things.

The concept later defined as social Darwinism had a great influence on the public opinion of developed countries of the nineteenth century. People accepted that the spread of civilizations was (to quote Kipling) 'the white man's burden' (see boxed text). This explains why European colonizing empires and the countries of the American continent showed no real (internal or external) resistance to colonization.

\section{The White Man's Burden}

\section{By Ádám Hoffer}

Rudyard Kipling, the English writer and poet born in India, is not only famous for his nice stories for children. His poem The White Man's Burden* became a symbol of nineteenth century colonization and the 'superior' thinking behind it.

The background of the poem is the war between the United States and the first Philippine Republic, during which Americans tried to maintain their annexed territories using arms. Kipling bitterly reminds the Americans that the 'half-devil and half-child' local populations hardly ever show gratitude for the formers' attempts at civilizing them.

“Kipling, Rudyard: The White Man's Burden. In: McClure’s Magazine, February 1899. 
The verses below express the vanity of the noble mission and the ungratefulness of those being 'protected':

Take up the White Man's burden-

Send forth the best ye breed-

Go bind your sons to exile

To serve your captives' need;

To wait in heavy harness,

On fluttered folk and wild-

Your new-caught, sullen peoples,

Half-devil and half-child.

...

Take up the White Man's burden-

The savage wars of peace-

Fill full the mouth of Famine

And bid the sickness cease;

And when your goal is nearest

The end for others sought,

Watch sloth and heathen Folly

Bring all your hopes to nought.

...

Take up the White Man's burden-

And reap his old reward:

The blame of those ye better,

The hate of those ye guard-

The cry of hosts ye humour

(Ah, slowly!) toward the light:

"Why brought he us from bondage,

Our loved Egyptian night?"

\section{Social Darwinism}

Charles Darwin's The Origin of Species, published in five volumes between 1859 and 1871, greatly influenced his contemporaries. His theory of evolution - that the creation of flora and fauna is due primarily to mutation ensuring biological diversity and to selection ensuring the selection of viable individuals - has been extremely significant in natural sciences ever since its publication. 
Darwin himself was never involved with debates about the development of society, and explicitly objected to the extension of his theory of evolution to the development of human societies and cultures. The term social Darwinism is thus somewhat deceptive: it was created in hindsight, ${ }^{51}$ we mostly associate it with negative connotations and many researchers who are now considered social Darwinists were opposed to Darwin at the time.

According to the social Darwinist concept, the diversity of human cultures (similarly to biological mutation) develops 'by itself,' and there is a kind of selection among cultures that leads to the survival of the strongest cultures: i.e. those that adapt better to challenges, with the unavoidable destruction of cultures less capable of development.

Of all the researchers considered social Darwinists, the aforementioned Herbert Spencer ${ }^{52}$ is usually referred to. Instead of Darwin's 'natural selection,' Spencer $(1864,1884)$ suggested the term 'survival of the fittest,' which he felt could be applied to the development of human societies. ${ }^{53}$ One of Spencer's followers, William Graham Sumner (1918), wrote: 'They do not perceive, furthermore, that if we do not like the survival of the fittest, we have only one possible alternative, and that is the survival of the unfittest. The former is the law of civilization; the latter is the law of anti-civilization. ${ }^{54}$

\section{Salvage Anthropology}

From a social Darwinist point of view, the conquering and reeducating of cultures considered inferior, or even the total destruction of a people, may be understood as an activity that promotes progress, ultimately serving for the salvation of the human race. In the second half of the nineteenth century, a kind of internal colonization was carried out on the American continent, during which the white man occupied vast, scarcely inhabited territories, eliminating the natives in the process (see boxed text).

The cultural researchers of the nineteenth century perceived the disappearance of 'aboriginal' ethnic groups and cultures as a realistic danger. Most researchers did not even try to stop the process of the destruction of

51 The term 'social Darwinism' was not used in the nineteenth century; the expression spread primarily due to a piece of work in 1944 by the historian Richard Hofstadter (Social Darwinism in American Thought, 1860-1915. Philadelphia: University of Pennsylvania Press).

52 Herbert Spencer published his first theories labeled 'Social Darwinist' before Darwin, in 1857, see: Progress: Its Law and Cause. In: Westminster Review, 1857. April.

53 Spencer, Herbert 1864: Principles of Biology. London: Williams and Norgate; Spencer, Herbert 1884: The Man versus the State. London: Williams and Norgate.

54 Sumner, William Graham 1918: The Forgotten Man and Other Essays (Albert Galloway Keller ed.) New Haven: Yale University Press. 
native peoples: on one hand, they felt helpless in the face of grand movements like colonization, and on the other hand (on a social Darwinist basis) they believed that even though you could feel sorry for peoples that were 'stuck' at a lower status of development, you could not save them. The activity labelled by posterity salvage ethnography or anthropology preferred to save the culture of Indians, as opposed to saving the Indians themselves: they wanted to collect things that could be saved: tools, objects of cult, folklore, or photographs.

The USA's Smithsonian Institute collected objects from disappearing cultures. The federal state institution was founded using the fortune of the British scientist, James Smithson; to quote Smithson's will: 'for the increase and diffusion of knowledge among men.' The Smithsonian Institute's ethnographic collection possessed material from expeditions organized by the United States - for instance, objects collected during the advance survey of the Transpacific railway line or during the moving of native peoples into reservations. (Most of these are now housed by the National Museum of the American Indian.)

One of the most famous representatives of salvage anthropology was the American photographer, Edward S. Curtis. He launched his project, The North American Indian, with private support, aiming for the publication of 1500 photos in twenty albums. The material collected by the 'shadow catcher' ended up much bigger than planned: he visited more than eighty tribes, took 40,000 photos and collected 10,000 cylinder recordings. President Theodore Roosevelt supported his work personally. In his introduction to the first volume (1907), Curtis clearly stated his intention: 'The information that is to be gathered [...] respecting the mode of life of one of the great races of mankind, must be collected at once or the opportunity will be lost.' ${ }^{55}$

${ }^{55}$ Curtis, Edward S. (1907): The North American Indian, vol. 1. Seattle: E. S. Curtis; Cambridge, Mass.: The University Press. 


\section{Enlightened Genocide on the Pampas}

The figure of general Julio Argentino Roca is inseparable from the discussion of the Argentinian belle époque at the turn of the nineteenth and twentieth century. The influential statesman was twice elected president of Argentina (meaning two six-year terms in office, totaling twelve years), and had a determining role during one more cycle. During his presidency, Argentina flourished: the country was reinforced economically, its society became open and multi-colored, Buenos Aires turned into an influential city on the world stage. European immigrants could quite easily settle in Argentina; equality before law according to gender, ethnic group, and religion was guaranteed by rights that at the time were rare even in developed countries. The completion of secularization, the introduction of free public education, and the building of a railway network all contributed to the modernization of Argentina. General Roca, nicknamed El Zorro, retired in 1904 after a thirty-year political career. In grateful posterity, several streets were named after him, his statues still stand, and a city in Patagonia preserves his name.

He was first elected President of the Republic of Argentina on October 12, 1880. By that time, Roca had pursued a successful military career (on the basis of Roth 2002).* 1 In 1878, as minister of defense, he was charged with solving the 'problem of border areas.' The borders between Argentina and Chile were not yet clearly drawn in Patagonia, and regular conflicts broke out between native peoples and settlers. Exploiting the atmosphere after a bigger battle with the settlers, Roca suggested a firm solution: the 'savages' must be displaced and/or driven out. The decisive battle turned out to be the occupation of Choele Choel, the base of the Araucan people in Patagonia, on 25 May 1879. At least 1300 Indians died and ten times as many were taken prisoner. Although the fight continued until 1885, the military campaign ended with complete 'success': the army resettled thousands of natives. Women, men and children were separated, partly to make them work, partly to prevent their further reproduction. This in practice meant the total destruction of the native population of Patagonia. According to contemporary evaluations, Argentina gained important territories for its settlers and thus for civilization, and reinforced its territorial position with regard to Chile. The 'results' achieved by the general were acknowledged by voters at the ballot box.

* Roth, Kenneth M. 2002: Annihilating Difference: The Anthropology of Genocide. University of California Press. 


\section{ETHNOGRAPHY}

\section{Introduction}

Ethnography is a discipline that was formed in Central Europe at the end of the nineteenth century, and is concerned with the exploration of culture. This discipline differs from cultural anthropology (be this called ethnology or social anthropology) in certain aspects, especially in its approach. Looking back at its history, there was no significant difference between Eastern and Western European, or American schools of cultural exploration, at the turn of the twentieth century. What is more, these schools were not completely detached from sociology. After World War I, however, ethnography and cultural anthropology grew further apart as a result of the increasingly isolated situation of Central and Eastern Europe. Institutes from the two disciplines went on to develop in different ways: scholars of ethnography and anthropology started independent journals in their respective countries, organized their own conferences, drafted different histories of theory, cited different authors, etc. What is more, ethnography was one of the few "fortunate" disciplines of Central and Eastern Europe which were allowed to exist within their own institutional frameworks (albeit amidst controversial circumstances) in most countries of the region - for instance, in Hungary and the Soviet Union (unlike sociology or cultural anthropology).

Presently, ethnography has its enthusiastic followers and apologists as well as its eagle-eyed critics. Efforts that have been made to protect and preserve values discovered during cultural research, for instance, are one "defense" of ethnography, along with the mental or even material reinforcement of folk culture (which has limited resources for protecting its own interests), or the imposing thoroughness which is typical of ethnographic fieldwork. On the other hand, "critics" reprimand ethnography for not having (sufficiently) progressed beyond the ethnocentric approach of the turn of the century, and for not facing up to the role ethnography played in totalitarian regimes. In the 1930s and 1940s, certain results of ethnographical studies created the ground for exclusionary thoughts and during the decades of socialism reinforced its arsenal of propaganda. On the other hand, for cultural anthropology, facing the role played by the discipline in colonialism led to a serious crisis and subsequent theoretical and methodological renewal in the 1960s and 1970s, but fresh ideas reached ethnography only with considerable delay.

The word "ethnography" in American books is used to denote "descriptive ethnography," meaning the methodology of anthropology, without regard to the over 100-year-old Central-European movement of cultural research which 
calls itself ethnography. Clifford Geertz (1973) for instance says this about the work of anthropologists: "if you want to understand what a science is, you should look in the first instance [...] at what the practitioners of it do. In anthropology, [...] what the practitioners do is ethnography. And it is [by] understanding what ethnography is, or more exactly what doing ethnography is, that a start can be made toward grasping what anthropological analysis amounts to as a form of knowledge. From one point of view, that of the textbook, doing ethnography is establishing rapport, selecting informants, transcribing texts, taking genealogies, mapping fields, keeping a diary and so on." ${ }_{56}$ Due to conceptual differences, it is extremely difficult to explain the difference between ethnography and anthropology to an anthropologist trained in the English or Spanish language.

The aim of this chapter is to elucidate the features of ethnography, and in particular Hungarian ethnography, starting from the introduction of the cultural context in which ethnography was born. Of these features, the present volume considers value-centeredness as the most important: while anthropologists usually strive for value-freedom, ethnographers regard cultural phenomena uncovered by their research as values, and they strive to preserve and maintain these, and, in many cases, raise awareness and recognition of them.

In the following chapter, we will first look at the wider context of the formation of cultural research in Central Europe, and then we will proceed to introduce and explain the development of Hungarian ethnography through the writings of three definitive researchers, János Xántus, János Jankó, and Zsigmond Bátky.

\section{National and Artistic Movements and Ethnography}

A number of historical-anthropological works of the twentieth century concluded that most twentieth-century nations were actually formed in the second half of the nineteenth century. Without exhausting the topic of a later chapter on the issues of ethnicity and nationality, let us comment on the fact that, according to the research of Eugen Weber, the majority of the people living in a significant area of France in the 1880s did not speak French. The French policy of assimilation involved millions - almost half the country's population up to $1914 .{ }^{57}$ The goal of politics operating in many areas of life (a

${ }^{56}$ Geertz, Clifford. "Thick Description: Toward an Interpretive Theory of Culture." The Interpretation of Cultures: Selected Essays. New York: Basic Books, 1973. 5-6.

57 Weber, Eugen. Peasants into Frenchmen: the Modernisation of Rural France, 1880- 1914. Stanford, University Press, 1976. 
political system that utilized devices such as extending state governance and education to the obliteration of the church, new street names, and erecting statues in public spaces) was to develop a common national identity, and ultimately, a nation state.

Efforts to forming nation states were also made in Eastern Europe. However, certain conditions were lacking in these territories. For example, one of the problems faced by the late nineteenth-century Czech nationalist movement was the fact that the leading political and economic elite were fundamentally German speaking, and of German identity - although it should be noted that at least Bohemia and Moravia did have historic foundations and certain regional autonomy. Polish nobility, however, was fairly stable in its national and linguistic identity, while Poland as such did not exist at the time, with its territory being divided up between the three great powers. Some ethnic groups had neither nationalist movements, nor political frameworks, nor a nationalist political elite with a commitment to their national language, such as the Slovenians and the Bulgarians. Compared to other nations, the generation of the Hungarian Reform Era were fortunate, although the fact that most of the aristocracy and the urban population did not speak Hungarian as their first language before the national awakening was an obstacle in that country. Understandably, pioneers of the national renewal reached out partly to historical precedent, and partly (just like Czech, Polish, Slovakian, etc. people) to the rural population for reinforcement. Contemporary intelligentsia "discovered" for themselves the village and rural culture in this period. The village became the font of untouched and clear mother language, religion, learning, etc., - the source of national culture. Ethnography, being developed in the 1870s, became the Central-European science of researching rural culture.

National movements in Central Europe had a unique way of becoming integrated with contemporary art movements. One of the earliest art renewal movements called itself the Pre-Raphaelite Movement: it was the firm belief of its adherents that the world had been ruined by Raphael. As the latter saw it, the fact that this Renaissance painter used to work for money, and good money at that (securing financial independence and a living through only his art), was unforgiveable. It was the pre-modern artisan who best reflected the movement's ideals: the craftsman who built his own house and made his own household items and furniture, thus deriving strength and inspiration from his self-built world from his authentic works of art. It was not personal fame, but the survival of his work that he was concerned with.

Pre-Raphaelite thought had a great impact later on many fin de siècle art movements, especially on the Art Nouveau or Jugendstil (known in Hungary as Secession) movement. After Pre-Raphaelite traditions had spread to 
Eastern Europe, many people thought that the medieval craftsman was the ideal artist, and such art could still be found among the nameless creators of rural Hungarian folk art.

Results of ethnography were swiftly integrated into national movements in each Central European country. In 1891, thanks to the financial backing of Artur Hazelius, 150 buildings from all over Sweden were bought and exhibited in the first open-air ethnographic museum ("Skansen"). It was this event that called attention to the beauty and values of this Swedish village which was once considered obscure. The Skansen significantly contributed to the development of Swedish design - an interior design movement using clean-cut shapes and few colors, yet radiating warmth.

In Poland during this time, it was Zakopane in the Tatra Mountains, (an area that cuts into the ring of the Carpathian Mountains, like a peninsula) that was considered to be the national landscape. However, it was the gorals people living in the mountains - not the polaks of the plains who were accepted as authentic representatives of Polish identity. Therefore, it was the gorals' mountain hut that became the basis of the Polish national architectural style.

In Hungary, the interaction between ethnography in the formation of national or artistic movements of renewal was palpable from the beginning: pencil sketches of Hungarian folk motifs by József Huszka, an art teacher turned ethnographer, appear on porcelain ware and glazed tiles, one of the most famous examples of which was copied on the façade of the Museum of Applied Art, designed by Ödön Lechner. Members of the Art Nouveau movement formed by the carpet-weavers of Gödöllö (for example, Aladár Körösföi-Kriesch, and Ede Thoroczkai Wigand), would go on field trips to Kalotaszeg and turn what they had seen or heard into art-nouveau interior design creations. Károly Kós also used to go on field trips on a regular basis to discover the rural architecture of Transylvania, which was incorporated into his own work and that of his colleagues (such as the buildings of the Budapest Zoo, the Wekerle Housing Estate, the church of Zebegény, etc.). Among the practitioners of Hungarian ethnomusicology (the study of folk music), many twentieth-century composers and teachers are known for having based the renewal of contemporary music on folk music: Béla Bartók, Zoltán Kodály, Antal Molnár, and László Lajtha are noteworthy representatives of this.

\section{Ethnography in the Early Nineteenth Century}

Two directions of cultural research were developed in the nineteenth century in Central Europe: in German, one was called Volkskunde (ethnography), the other Völkerkunde (the study of peoples). 


\section{Völkerkunde, or comparative ethnography}

Völkerkunde, or comparative ethnography, was strongly influenced by British anthropology and French ethnology. Its primary focus of research was the development of a universal human culture. With an evolutionary perspective, its mission (similarly to contemporary anthropology) was to enable scholars to assemble the mosaic of universal culture and its development based on information from all around the world. There is one important difference, though: unlike British anthropology or French ethnology, ethnography was never strongly influenced by social Darwinism. This, among many other reasons, was due to the impact of romanticism and the absence of colonisation.

Public opinion in Central Europe was strongly favorable toward distant, exotic peoples. This situation was further reinforced by romanticism (still dominant, owing to its late arrival in Central Europe at the end of the nineteenth century). Cheap oil prints and romantic depictions of gypsy caravans, Arabs wandering across deserts, and Red Indians hunting buffalo were common components of bourgeois interiors. The novels of Karl May (a German romantic writer) were very popular, in which were described the noble and heroic Indians of the American West.

The fragment "The Wish to Be a Red Indian" by Kafka was inspired by the romantic image of Native Americans

Franz Kafka:

Wunsch, Indianer zu werden

Wenn man doch ein Indianer wäre, gleich bereit, und auf dem rennenden Pferde, schief in der Luft, immer wieder kurz erzitterte über dem zitternden Boden, bis man die Sporen ließ, denn es gab keine Sporen, bis man die Zügel wegwarf, denn es gab keine Zügel, und kaum das Land vor sich als glatt gemähte Heide sah, schon ohne Pferdehals und Pferdekopf.

In: Betrachtung. Ernst Rowohlt Verlag, Leipzig, 1912
Franz Kafka:

The Wish to Be a Red Indian

If one were only an Indian, instantly alert, and on a racing horse, leaning against the wind, kept on quivering jerkily on the quivering ground, until one shed one's spurs, for there needed no spurs, threw away the reins, for there needed no reins, and hardly saw that the land before one was smoothly shorn heath when horse's neck and head would be already gone.

transl. Willa and Edwin Muir 
Differences between Eastern-European and Western-European schools of cultural research also stem from the disparity between their roles in the nineteenth-century race for colonization. Central European researchers had little to no chance of travelling to colonies ruled by their own countries. Due to the absence of colonies, ethnography could not become an applied discipline in this region in the same way as British or French anthropology: researchers did not enjoy the support of colonizing powers during comparative research among distant peoples, and a sense of white superiority and/or civilizing missionary duty did not become part of official policy. Hungarian researchers/ explorers, including Sándor Körösi-Csoma (Tibet, Ladakh), Aurél Stein (Dunhuang), Ármin Vámbéry (Samarkand, Bukhara) among others (who could never do research in their country's own colonies) suffered from bureaucracy, a lack of support, and the additional taxes imposed by colonizers.

"Living and making a living are two different things, for me especially" writes Lajos Bíró in Papua, a German colony at the turn of the century. "My European colleagues over here only need to take care of the former. The latter is taken care of right at their arrival, through wealthy institutions which are familiar with local circumstances. [...] All they need to take care of is staying alive... I alone am a free man, at liberty to make a living and stay alive - as best I can." ${ }_{58}$

The German scholar Adolf Bastian, and Russian scholar Mikluho Maklaj both belong among the most notable representatives of comparative ethnography and the founders of their respective national ethnographies. See the text below on Adolf Bastian's life work.

${ }^{58}$ Lajos Bíró's letter is quoted in Zoltán Benedek: From Sylvania to New Guinea. (A Szilágyságtól Új-Guineáig.) Bucharest: Kriterion 1979. 
Adolf Bastian, founder of ethnography

by Ádám Hoffer

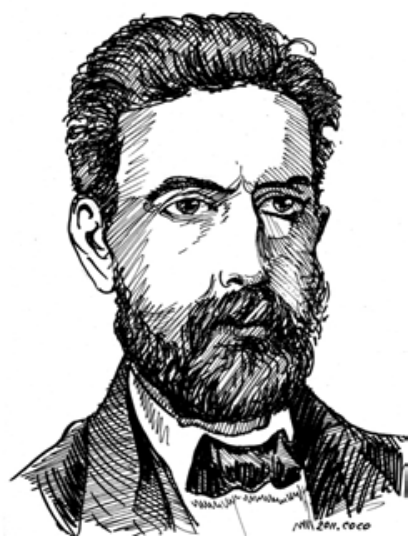

Adolf Bastian

(1826-1905)
Visiting the Ethnologisches Museum in Berlin, one will certainly become acquainted with the memory of Adolf Bastian, who was the founder and first curator of the institution, as well as a pioneer of German comparative ethnography.

As a young man, Bastian studied law, medicine, and natural science. Like most twenty-somethings, he longed to travel and adventure after his university studies. He travelled around the world as a doctor employed on a ship, visiting Peru, Central-America, India, and Africa. During his travels, he observed the local cultures wherever he went, and recorded his experiences

in his book, Der Mensch in der Geschichte, published in 1860." Thus, he became the first German ethnologist to do systematic fieldwork.

Bastian's views on the different ethnic groups and the development of their cultures differed from those held by most of his contemporaries. According to the consensus of his age, humanity consisted of races which followed isolated paths of development. Bastian, however, hypothesized that humanity is one big family with a shared origin. Although he believed in development, his evolutionary theory was non-unilinear. According to his theory on elementary and folk ideas (Elementargedanken, Völkergedanken)," there are certain elementary ideas (today we would call them cultural patterns) everywhere in the world which prove the unity of the genus human. However, as a result of different environmental and historical impacts, folk ideas also appear, indicating the differences between cultures as they become differentiated from their foundations.

In 1869, Adolf Bastian and his colleague Rudolf Virchow (also a doctor and anthropologist) founded the Anthropological Society of 
Berlin (Berliner Anthropologische Gesellschaft). Afterwards, in 1873, Bastian was one of the founders and first curator of the Royal Museum of Ethnography (Königliche Museum für Völkerkunde, today the Ethnologisches Museum). He did much to ensure that his institution would be famous around the world: right from the start, the collection numbered 500,000 objects.

The founder of a school of American cultural anthropology, Franz Boas, worked between 1885 and 1886 under Bastian's supervision in the Museum of Ethnography in Berlin. Bastian's influence shows clearly in Boas' first work - his writing about the Inuit of Baffin Island." Bastian's perspective, according to which humanity forms a "mental unit" and differences between ethnic groups are not determined by biological factors, were in harmony with Boas' experiences. Later, Boas was to further develop the idea of multilinear evolution in his essay on cultural particularism.

* Bastian, Adolf. Der Mensch in der Geschichte. Leipzig, 1860.

** Bastian, Adolf. Allgemeine Grundzüge der Ethnologie. Berlin, 1884; Die Lehre vom Denken zur Ergänzung der Naturwissenschaftlichen Psychologie, für Überleitung auf die Geistewissenschaften. Berlin, 1902.

*** Boas, Franz 1888: The Central Eskimo. In: Sixth Annual report of the Bureau of Ethnology, 1884-85. Smithsonian Institution - Bureau of American Ethnology.

\section{Volkskunde, Central-European Ethnography}

The aim of Volkskunde studies or ethnography (in collaboration with national and artistic movements of renewal) was to enable researchers to better understand their own cultures. Ethnography differed in many aspects both from contemporary anthropology and the Völkerkunde approach that was akin to it; naturally, the similarities were as great as the differences. In what follows, we look at some of the different aspects.

\section{Primitive versus ancient}

Both anthropology and ethnography were involved in a certain "race" for the discovery of ancient cultural markers, but both had fundamentally different sources of motivation. Anthropological expeditions, if they could bring news of the "discovery" of an Iron Age or Stone Age society, valued their results because of their rarity (just like philatelists). The "value-seeking" attitude of ethnographers, however, originated from the applied purpose of their research (the exploration of authentic sources of culture): those who researched their own cultures and came across ancient (i.e. primitive) cultural markers did 
not attribute these to the backwardness of the cultural group in question, but to the unspoilt purity of that group. The meaning of the word primitive, of Latin origin, and that of ancient, as used in the national language, diverged sharply, with the former having a negative and the latter a positive connotation.

\section{Who civilizes who?}

Ethnographers reversed the "civilizing mission" of colonizing powers. Representatives of evolutionist anthropology largely agreed with the popular opinion which held that it was the duty of European nations to transmit developed culture to African, Asian, etc. peoples who had "dropped behind." Central-European ethnographers, however, believed that in "primitive" rural culture (from folk tales to fishing equipment) they could find the authentic elements of national culture, and it was the former's mission to popularize these markers among their "civilized" (that is, urbanized) fellow citizens.

\section{Ethnocentrism}

Although both Eastern and Western cultural research valued the results of its own culture over others, they were motivated by different factors. In the East, ethnocentrism was nourished by nationalism, and in the West by faith in development. According to the latter, since all cultures had to climb the same stairs, the researcher that represented the most developed culture (British, French, etc.) could take their own culture as a point of reference, and measure all other, more primitive, cultures against it.

\section{National research questions and results}

In Eastern Europe in the nineteenth century, the results of ethnographic research were often integrated with important elements of national identity, and conversely, research into national characteristics often set the direction of ethnographic research. For example, the election of Sándor Solymossy (head of the first department of ethnography in Hungary, created in 1929) to the Academy of Sciences was justified by saying that he "regards the flourishing of Hungarian ethnography as a national interest, hoping that it will bring the salutary healing of social rifts, and sees in it a clear source of national regeneration." ${ }^{\text {"59 }}$ László Kósa (2001) which emphasizes that national idea, however, "prevailed differently in each country and for each group. It was different for those who lacked a written culture of long history, and different for those on the opposite pole, for instance [in Germany] where nationalism was used to support the ideal of the empire. For the former, nationalism was

\footnotetext{
59 Quoted in Kósa, L. 2001 A magyar néprajz tudománytörténete. (The History of Hungarian Ethnography) Ch. 5. Budapest: Osiris. The following citation is from Kósa L. (2001).
} 
a supplement for high culture, for the latter, it served to draw attention to the Eastern islands and diaspora - not without political motives. One thing, however, connected the different national ethnographies: the quest for the 'ethnic specifics,' those ethnic features deemed to be constant, continuous, and ready to be integrated into the modern national identity."

\section{The ethnologist studying their own culture}

Edit Fél (1991) ${ }^{\circ 0}$ summarized the differences between the Eastern-European ethnographer and the ethnologist/anthropologist in three points. First, ethnographers "belong to the larger ethnic unit covering the local societies they study, sharing a first language, experiencing history within the same societal framework. Secondly, their vision is influenced by the fact that they received academic training as Hungarian ethnologists and start out in research with information gathered by previous generations of Hungarian ethnologists. Finally, their vision is influenced by the fact that as researchers, they belong to the university educated minority elite of that same society within which the rural people they study are also situated... - regardless [of] whether these researchers make an effort, or are able to step beyond social norms and rules of communication."

After the dissolution of colonial empires, representatives of Western anthropology also "returned home," studying questions pertaining to their own cultures instead of distant, "exotic" cultures - in this sense, ethnography preceded ideas of its time.

\section{Discoverers and Field Workers}

Western anthropologists in the nineteenth century were typically armchair anthropologists who obtained their data from the "real" discoverers - that is, participants of field expeditions, or from other reports (from missions, colonies, etc.). Demand for fieldwork in cultural anthropology appeared only decades later, in the 1920s. Ethnographers, on the other hand, regarded fieldwork, the personal collection of information and data, as something important in the nineteenth century. Ethnographers often regarded themselves as discoverers: discoverers of the village. Many methods of fieldwork (for example, network analysis, or mental mapping, which are popular today) appeared in ethnography and anthropology decades before they did in other social sciences.

\footnotetext{
${ }^{60}$ Fél, E. 1991: "A saját kultúrájában kutató etnológus." (“The Ethnologist Studying Their Own Culture.") Ethnographia. 1-2/102, 1991. 1-2.
} 


\section{Applied research}

Although both the Eastern and the Western schools of culture research can be said to have been, to a significant degree, applied sciences, this "resemblance" led to a deepening of differences. In the nineteenth century, anthropological research was supported by colonizing powers which led to international, comparative data. The results of ethnography, however, were used to strengthen national movements. In the twentieth century, the Volkskunde approach of ethnography became stronger, due to the demand of young Central-European nations for strengthening national culture. In the age of a succession of dictatorships, the demand for comparability decreased even further, and the results of ethnography responded less and less to the great international questions and challenges posed by cultural anthropology.

\section{The relationship between researcher and the subjects of research}

The evolutionary anthropologist, as the representative of a more developed culture, did not regard the primitives they were studying as their equals. Ethnographers did not regard the subjects of their research as their equals, either. However (in direct contrast to anthropologists), this was because they located the field they were studying (rural man, and rural culture) on a pedestal. Ethnography is often called "the clear source" (after Bartók's Cantata Profana and the ballad of The Nine Miraculous Stags).

\section{Ethnography and anthropology in China}

The institutionalization of cultural research in China received a lot of momentum in the first third of the twentieth. century. Two big knowledge bases solidified towards the 1930s: the Northern school of thought at the University of Yenching, and the Southern one, based at the Chinese Academy (Academia Sinica), founded in 1928 (Quinlan 2000). A lot of differences became apparent between these two schools. The former primarily focused on village research in the framework of the Han population, while the Chinese Academy was mainly interested in ethnic minorities. Academia Sinica was subject to substantial Anglo-Saxon influence, and the Yenching school built mostly on German scientific foundations (mostly through literature translated into Japanese). Ethnographic, architectural, and folklore research were not sharply separated in the southern schools' research practice (similar to the f.e. Latin-American anthropological tradition), while in the Northern schools' practice ethnographic and sociological methodological considerations were intermingled (Dirlik et al. 2012).

Not considering Western sciences to be fully applicable in China was a view characteristically shared by both movements. One of the keywords in the 
intellectual lingo became Chineseization (zhongguohua, 中国化). Liangshan Yi (1947), considered a staple by its contemporaries, formulated the principles of Chinese Sociology (社会学的中国化, shehuixue de zhongguohua). Aside from the usual scientific principles, the latter book contained uniquely Chinese approaches, such as community investigations (社区研究, shequ yanjiu).

The Second World War and the later years of civil war were not too kind on the process of the solidification of the roots of social sciences. In Taiwan, however, the taking over of Japanese-built anthropological institutions and museums into local hands had begun by 1945 , while after the civil war in 1950-51, a series of social- and cultural research institutions sprung up, mostly through institutions that moved in from mainland China. Taiwanese anthropology based itself mainly on the Southern school of thought, and on the traditions of Academia Sinica - so much so that the institution still presently operates in Taiwan. This tradition fits very well into the AngloSaxon anthropological traditions and institutional environment. Archeology, museology, physical anthropology, and contemporary culture research are not sharply separated in Taiwanese anthropology.

Different processes played out in the People's Republic of China. The Chinese Scientific Academy was founded in Peking, in 1949. The Soviet model for institutionalization was determinative for a long time - for example, in the fact that for almost two decades the practice of sociology was not allowed to exist separately, but rather only within the framework of Marxist-Maoist philosophical institutions, in the form of social philosophy and research (Guldin 1994). This practice was similarly shared throughout communist countries, such as Hungary until the 1960s, and Romania even until the 1990s (Hann et al. 2005). In the 1970s, social sciences slowly got their strength back, alongside support from China. In 1977, the Sociological Institution was formed (in the beginning as part of Marxist philosophical institution), in the framework of the Chinese Scientific Academy (CAS, 中国科 学院), followed by a number of training centers and journals. The two leading journals in China are the "Journal of Sociological Research" (JSR, Shehuixue Yanjiu, since 1986) and "Society" (Shehui, since 1982). Regarding cultural research, the collecting of folklore in the areas of non-Han nationals was allowed at all times, even during the civil war (Chen 2010). This trend can has parallels with the middle-European ethnographic tradition. The new keyword in China with regard to cultural research became internalization (bentuhua 本土 化). Since the basis of the word is the native word for people/folk in China, we can also call it nativization too (Bilik 2001; Chang 2005). The term implies a rethinking of its predecessor movement zhongguohua (Chineseization), with the caveat that cultural research aims not at society as a whole, but rather particularly at smaller communities, and mostly nationalities (Pieke 2009) and diasporas 
(Chow 1993). Regarding the anthropology that is accepted in the mainstream international scene, in the People's Republic of China, this is simply called oversee ethnography (haiwai minzuzhi，海外民族志) (Wang 2011; Fahim and Helmer 1980).

In summary: although the branches of Chinese cultural research stem from the same roots, there are substantial differences in the situation of the latter between the two coasts of the South-China Sea, which can be portrayed as having a parallel with the Western differentiation between ethnography versus cultural anthropology.

\section{References:}

Bilik, N. 2001a. "Chinese openness and anthropology's nativization," Chinese Sociology \& Anthropology 33(4): 49-58.

Chang, M. 2005. The movement to indigenize the social sciences in Taiwan: Origin and predicaments. in: J. Makeham and A.-c. Hsiau (eds.), Cultural, ethnic, and political nationalism in contemporary Taiwan: Bentuhua, 22160. New York: Palgrave Macmillan.

Chen, K.-H. 2010. Asia as method: toward deimperialization. Durham, NC: Duke University Press.

Chow, R. 1993. Writing diaspora: tactics of intervention in contemporary cultural studies. Bloomington, IN: Indiana University Press.

Dirlik, A., G. Li and H.-p. Yen 2012. Sociology and anthropology in twentiethcentury China: between universalism and indigenism. Hong Kong: Chinese University Press.

Fahim, H. and K. Helmer 1980. "Indigenous anthropology in non-Western countries: a further elaboration," Current Anthropology 21: 644-63.

Guldin, G. E. 1994. The saga of anthropology in China: from Malinowski to Moscow to Mao. New York: ME Sharpe.

Hann, C., M. Sárkány, P. Skalník (eds.) 2005. Studying Peoples in the People's Democracies: socialist era anthropology in East-Central Europe. Berlin: LIT Verlag. Halle Studies in the Anthropology of Eurasia

Pieke, F. 2009. "Introduction: A Chinese century in anthropology?", Social Anthropology 17: 1-8.

Quinlan, T. 2000. '“Anthropologies of the South. The practice of anthropology." Critique of Anthropology 20: 125-36.

Wang, M. 2011. "Haiwai minzuzhi [The so-called overseas ethnography]," Xibei minzu yanjiu [Northwestern Journal of Ethnology] 2: 116-29. 


\section{Comparative and National Ethnography: The Case of Hungary}

The first Hungarian ethnographers practiced comparative ethnography, or contemporary anthropology. It is an interesting contradiction that the practice of anthropology in Hungary was not started by a demand for information about colonies, but rather by the country's semi-colonial fate, which, after the unsuccessful war for freedom in 1848, forced many intellectuals into exile. A great number of the emigrants of 1848 produced outstanding reports on the Balkan countries or Asia Minor, North-America, and South-America, among other places. The example of János Xántus clearly shows the efforts of this generation of emigrants; another reason why it is apt to start discussing the emergence of Hungarian ethnography with him, is the fact that as an organizer of the Budapest Zoo, leader of many ethnographic expeditions, and especially as the founder of the Museum of Ethnography, he is revered as the institutional creator of Hungarian ethnography.

\section{János Xántus, founder of Hungarian comparative ethnography}

Xántus served first as volunteer guardsman, then as a lieutenant in the freedom fight in 1848-49. In 1849 he was captured, and after many attempts to escape, finally fled to England through Germany. He left Europe for the USA in 1852.

Xántus lived and worked as a pioneer and scholar in the United States. He worked on the mapping of the railway lines planned for the Western states, then as an adjutant in a military hospital. Wherever he went, he had the opportunity to better observe the untouched, natural world of the frontier. As a hunter, collector, and taxidermist, he did valuable research in natural science, and regularly sent his results to the Smithsonian Institute. His name is associated with the collection and categorization of many animal and plant species (quite literally: the prefix Xantusi features in the Latin names of these species). Mediated by the Smithsonian Institute, part of his collection ended up in the National Museum of Hungary.

His letters to his relatives were published in 1858 in Pest, entitled János Xantus's Letters from North-America, to enormous success. Karl May, the German writer, contacted the author of the romantic journals through letter, asking for permission to model "Old Shatterhand," the character of his novel, then a work in progress, after him. ${ }^{6}$

61 Karl May's letter to János Xántus can be seen in the Karl May Museum in Dresden. The letter was recovered as a result of Franz Rammel's archival work. The topic is clearly summarized in Gábor Xantus' documentary (2006): Magyar volt-e Old Shatterhand? (Was Old Shatterhand a Hungarian?) '55. 


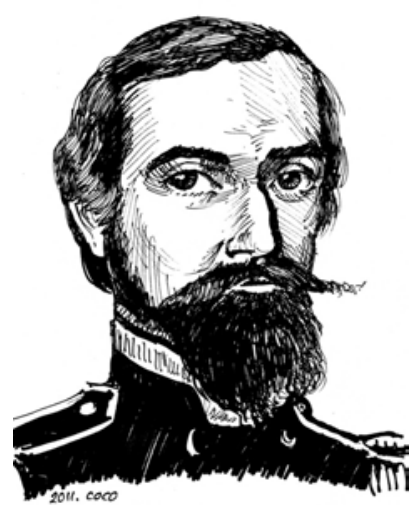

János Xántus (1825-1894)
In 1859, he became a corresponding member of the Hungarian Academy of Sciences in acknowledgment of his scholarly merits. In the USA, he received increasingly prestigious government commissions: from 1862 he was consul to Manzanillo in Mexico for a short time, then in July 1864, after he was elected to chair the committee organizing the zoo in Pest, he moved back to Hungary for good. In Hungary, he was not only a founder of the zoo, but also its first manager following its opening in 1866. (As we have explained in the chapter on Evolutionary Anthropology, zoos at this time were also involved with the display of cultures of distant continents, besides flora and fauna.)

In 1868, he took part in the Austro-Hungarian expedition in East-Asia where, besides collecting natural science objects, he was also entrusted with acquiring ethnographic material. During the twoyear study trip (the second half of which he completed as an independent collector), he did research in Ceylon, China, Japan, Borneo and Java. With the help of material and knowledge accumulated there he became the curator of the Ethnography Department in the National Museum - this department was later to become the Museum of Ethnography. The date of his appointment (5 March 1872) is traditionally commemorated with a series of programs every year by the Museum of Ethnography.

The selection from Letters from North-America below allows us some insight into the early reports of the adventurer-scholar Xántus. ${ }^{62}$ Although the letters are telling from an ethnographic point of view, our goal here is to point out the fact that the social-Darwinist approach was clearly not pursued by the Hungarian scholar. In fact, he felt his approach was closer to that of the Native Americans who had chased away from their land than to the European victors of the time who had sent him into exile.

Letters by János Xántus from North-America (Pest, 1858). Extracts.

"We are on the territory of the Indian tribe the Seminoles (fugitives), and I have ample occasion to learn about their circumstances.

The men wear tight deerskin trousers ornamented by a voluminous tassel at

62 János, Xántus (1858) 1975: Letters from North-America, Detroit: Wayne State University Press. The quoted text is from the Hungarian original, Xantus 1858: 9-10. 
their calves; then they wear moccasins (deerskin shoes) with red, blue and yellow beads sewn on them, and tight jackets also of deerskin. Their throats are naked and decorated with red and yellow paint, as is the line of their forehead and nose. Their hair is cut in the shape of a rooster's comb, pressed into a bone hoop which is strewn with gaudy parrot feathers standing on end. The quiver on their back is full of arrows, and they carry the bow in their left hand.

The women are not that comely in shape; their costume consists of a single piece of red clothing (made from cinnamon) hanging down front and back, like a Hospitaller's scapular. The women wear shoes with shells sewn on them, but the maidens go barefoot. Their hair is, without exception, very beautiful, cascading in carefully curled tresses on their shoulders; their neck is laden to overflowing with beads and colibri [hummingbird] feathers. Their nose is painted blue, their lips red, their cheeks and forehead yellow, and they make the various paints from the juices of different sorts of herbs and trees, therefore these are harmless. Their food consists mostly of game, baked in one piece in cinder after being filled with aromatic herbs, and is, needless to say, very tasty; they also make many kinds of vegetable dishes, cooked to a turn with wild berries.

They all live in bulrush tents, and a row of 20-30 of these tents is very similar to a gypsy village. Right across them, on the other side of the river there is another village of 17 wigwams (tents), and the chief has already taken me over there in his canoe, showing and explaining everything with the help of their translator." [...]

"After the translator introduced me and told the chief that I had come from beyond the great water, the chief asked: 'why?' - upon which the translator replied: 'because he had been driven out of his country.' The chief took his pipe from his mouth, took his right shoe off and handed it over to me as the greatest sign of friendship, saying: 'You are a true neka (good friend) to me, for you, as well as we, have been driven out of your land, accept these tokens of my friendship, and stay with us, we are mighty,' etc. Then we exchanged pipes, and while we were smoking them, my new friend offered that I should choose a wife from one of his daughters - for which I, of course, thanked him, promising to carefully contemplate this important matter.

This is the way I live now, brother, and I'm only sorry that you are not here, as you usually are when life is treating me well." 


\section{János Jankó, an outstanding representative of national ethnography}

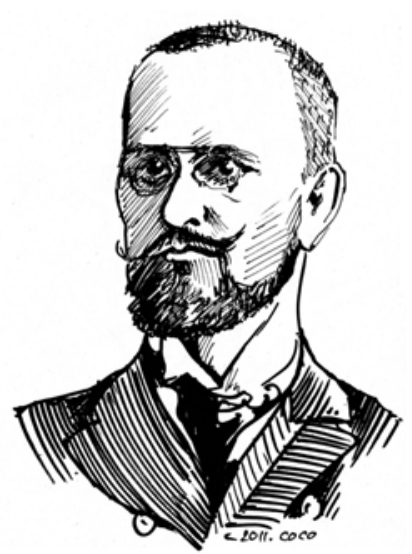

Jankó János

(1868-1902)

The Hungarian Ethnographic Society named their prize for young researchers after János Jankó. They chose János Jankó because he achieved everything he could as a researcher while he was still very young. The son of a painter from Tótkomlós, he received his doctoral degree at the age of 22 , and was also elected secretary of the Geographical Society. From the age of 26 , he was the curator of the Museum of Ethnography (then still a department of the National Museum). By the time he died at the age of 34, during fieldwork in Transylvania, he had already traveled throughout Eastern and Western Europe, done fieldwork in the Sahara and in Siberia, and written over 30 books (mostly ethnographic monographs and studies). Jankó's work belongs more to the Volkskunde approach than that of comparative ethnography.

Being a scholar with a wide perspective, he visited each museum of ethnography/ethnology in Europe as a matter of official duty. Naturally, his Hungarian colleagues who were working on comparative ethnography influenced him greatly. Nevertheless, his vocation, first and foremost, was to uncover Hungarian rural traditions. Even during his work in the most remote areas, among speakers of the Khanti language (a language related to Hungarian), his primary purpose was learning about Hungarian traditions. To quote his own words from the introduction to his article on shamanistic religion: ${ }^{63}$

\footnotetext{
"Hungarian ethnographical research, during the last decade, focused its main effort on shedding light [on] the ancient history of the Hungarian people. The most interesting aspect of this effort is, undoubtedly, the aspiration to reveal the ancient Hungarian belief system. This task, however, is as difficult as it is interesting. It is obvious that the comparative method is inadequate for it and we need to gather all the material reflecting the remains of our ancient religion, and having processed that material, we
}

63 János, Jankó. "Resources for Shamanistic Religion." Ethnographia, 1900 (in book form: Debrecen, Főnix Könyvműhely, 2000). 
need to compare it to the religion or the surviving fragments of it, of peoples related to us through language, blood, or history."

The following extracts are taken from The Hungarian People of Kalotaszeg, written by János Jankó at the age of $24 .{ }^{64}$ This book, containing extraordinarily thorough descriptions on over 200 pages that reflects Jankó's thorough knowledge of his subject, was based on a barely three-month (obviously very intensive) period of fieldwork. The work was one of the first ethnographic reports on this area, and subsequently continued to attract significant attention in artistic and ethnographic circles.

Artisanal products from Kalotaszeg first achieved success at a number of Hungarian exhibitions, and then in the pavilions of the World Exhibitions in Paris 1900, and St. Louis 1904. Embroidered cushions and tablecloths became fashionable throughout Hungary. Artisanal products continue to be the basic source of income in many villages in Kalotaszeg, especially at Körösfő (Isvoru Chrisului), even today. Károly Kós took the church of Körösfö as his model for the birdhouse in the Budapest zoo. Volume One of The Art of the Hungarian People, a series published under the name of Dezső Malonyai, appeared in 1907 entitled The Art of the Hungarian People of Kalotaszeg. This richly illustrated volume became an enormous success and remains the greatest Hungarian business venture in ethnography.

The extracts I have selected from Jankó's book shed light on the meanings of ethnocentrism, value-centeredness, and the absolute respect shown by ethnography to the inhabitants of the area. The extracts will inevitably cast both the author and his book in a negative light, therefore (to offer some weak compensation), I would like to note that the book's impact was not due to its ethnocentric features. Many of his observations have stood the test of time. To name but one: when writing about part of the embroidered flower motifs from Kalotaszeg, he concludes that these do not originate in some old Hungarian love of pomp, but in the store of motifs at the medieval ducal court; owing to the ingenious servant girls of aristocratic households, Baroque elements became integrated into folk art. This hypothesis, formulated when Jankó was 24, has only been reinforced by ethnographic studies during the past 120 years.

Extracts from The Hungarian People of Kalotaszeg by János Jankó (1892):

"The subject of our study is thus comprised of those 17,964 Hungarians living in the above listed 34 conjoined villages which constitute a homogeneous island of

64 Kalotaszeg is a region in Transylvania, nowadays Romania. Citations are from János, Jankó (1892) 1993: Kalotaszeg magyar népe. Budapest: Ethnographical Museum, 4-9., 102-103. 
population. The rest of Hungarian society, not included in our discussion, spread out from small pockets scattered among the Rumanian majority, as it is obvious to anyone glancing at the linguistic map of Transylvania. In what follows, we are only concerned with the rounded number of 18,000 Hungarians who constitute the core of the Hungarian people of Kalotaszeg.

The primary profession of the Hungarians of Kalotaszeg is agriculture; in this area, they are good husbands, industrious workers who excel at dividing up their time. [...] Thus, the men of Kalotaszeg are strongly speculative, agile in mind and of lively blood; these are people who buy cattle at a profit, buy corn in the autumn and sell it in the spring, lend money at interest, etc. The mercantile spirit is particularly strong in the people of Bánffy-Hunyad, they buy and sell anything, are not rooted to one place but if they have a chance of making a profit, they will travel to Kolozsvár or as far as Nagyvárad instead of waiting for agents to come to them, thus pocketing the agents' share in the profits as well. Bánffy-Hunyad is the centre of trade with a weekly market on Tuesdays to which people from the whole area gather.

Market day is the most eventful day of the week at Bánffy-Hunyad. [...] Women have a strikingly great role in trade, much bigger than the men, and save for the few Jewish tradesmen, almost every branch of trade is in the hands of women, which naturally guarantees them great independence. On market days, every house in Bánffy-Hunyad turns into a hotel. For a little money, much less than would be charged at a regular hotel, one can enter, both cart and horse, into any yard and spend the night in one of the rooms, should he arrive a day early and depart to the market straight from the house. [...]

The Hungarians of Kalotaszeg are possessed with a strong sense of racial identity. With a tenacious grip on their traditions, they keep every foreign influence far away from themselves, and although they do not engage in minority politics and get on peacefully with Rumanians, they do not allow the latter to advance upon them at the present. Interracial mixing is out of the question; for proof of this, it is enough to look around at Bánffy-Hunyad on market day to see how pure, strong, healthy and beautiful the Hungarian race is. ... Although the people of Kalotaszeg profess themselves pure Hungarians, they bear traces of other ethnicities in their traditions, a fact not infrequently reinforced by certain character traits. They tend to speak positively about a certain relationship with the Mongolians, claiming they are the descendants of Mongolians settled here by György Rákóczi II. A look at their faces will suffice to convince us how their prominent cheekbones, marked eyebrows, sparse beards and other anthropological features show this. The people of Darócz are considered to be Saxons, and generally described as industrious, thrifty, but selfish people. The people from Inaktelek and Bogártelek claim to be closely related to the people of Bánffy-Hunyad. The idea of a Sekler connection comes up now and then, and there are undoubtedly sufficient elements in folklore to corroborate this. I would mention only one of these, the kalaka. 
From an anthropological point of view, the people of Kalotaszeg are most comely. Men are of middle height or taller, their body strong and muscular but by no means fat or inclined to be obese. Their head is, generally, brachycephalic, with a high, wide and straight forehead, marked eyebrows which almost touch. Their eyes are more blue than brown. Their nose is straight or Roman, regular. The lips are thin, red, arched downwards. Their chin is wide and protruding. Their hair is fair in childhood and darkens afterwards to auburn, but mostly it remains light and never becomes black. Individual hairs are wavy, not rough, the hair itself is thick. Moustache and beard tend to be lighter and thinner than the hair; moustaches are pointed, beards shaved off. Their face is very slightly oval, but round faces are also common. Their limbs are in proportion and strong. The tan of their body comes out in a blush and 'glow' in their face.

The women belong among the most beautiful peasant women of Hungary. The girls' faces are regular, round; the inner part of their eyes are deep-set, the eyebrows are neither marked nor thick; the line of the eyes is very delicate, can be either blue or brown in color but always lively, fiery, clear. Their noses are very regular and straight. The line of the mouth is straight, that of the upper lip is bowed. The lips are not too thick, they are bright red and plump with blood. The forehead has a gentle dome, the chin is round. The hair is fine, thick, and wavy. Their complexion is white with the bright red roses of life: the cheeks are firm and glowing with health. The woman of Kalotaszeg is beautiful and healthy in body, too. Her breast is well developed, round, the nipples are hard, not drooping, her hips are wide, her limbs regular, shapely, strong. As the men's manner is calm, measured, and sober, so that of the girls is simple, modest, with only a modicum of vanity and even less flirtatiousness. The young women and matrons, however, are generally very lively and full of tricks, and haven't got a very good reputation with regard to their morals either. [...] It is beyond the scope of this work to give a detailed account of the economical, cultural, and other circumstances of the people of Kalotaszeg. The few data presented in the above lines is meant to describe this group in the most general terms... I can feel that the chief shortcoming of my work is the complete absence of comparison, but this is not my fault. In the entire Hungarian literature, I couldn't find a description of any group of the Hungarian people as detailed as mine which, nevertheless, I still do not regard as exhaustive. When more works of similar direction and length will lie before us, then we can start the laborious work of drawing comparisons, attending to every detail. Therefore I consistently stick to gathering data throughout, and if, on the one hand, I keep my distance from comparisons, I also, on the other hand, stay away from drawing conclusions which, in my opinion, can only be based on comparisons." 


\section{Zsigmond Bátky, an ethnographer with a European perspective}

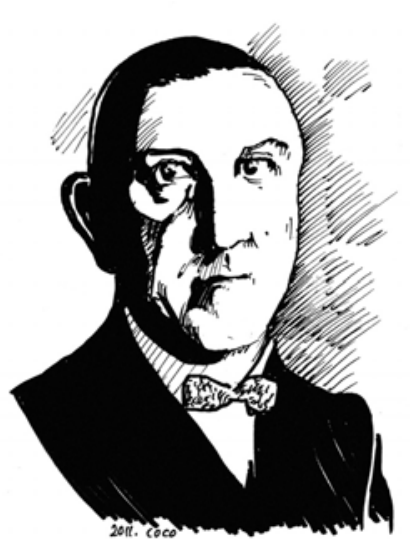

Zsigmond Bátky

(1874-1939)
Zsigmond Bátky was born in Kocs in Transdanubia and had a degree in geography. He started working in the Museum of Ethnography (or its predecessor) in 1896, the year when the millennial festivities were a great burden on the shoulders of the institute's curator János Jankó: he had to organize the millennial village. The open-air multiethnic museum, consisting of 24 homesteads, was equal to the Skanzen of Stockholm, which was opened a few years prior. Bácsky played a major role in the practical task of organizing the exhibition.

The buildings of the millennial village were dismantled that same year, but the exhibited material went to the Museum of Ethnography - where a sizeable quantity of Hungarian

material occupied space alongside foreign collections for the first time. A so-called "cottage museum movement" started up around the country, within the frameworks of which more and more towns set up exhibitions in local buildings considered characteristic of the region. In 1906, Zsigmond Bátky published a manual with the clear-cut title $A$ Guide to Setting Up Ethnographic Museums. This book has been mandatory reading for students of ethnography ever since, and is a collection of practical suggestions for local patriot ethnographers. It contains details such as what one should say in a village to acquire objects of ethnographic value for a low price.

After World War I, Bátky assisted Hungarian intellectual efforts against the dictates of Trianon through the making of detailed ethnic maps. He became curator of the National Museum of Ethnography in 1922, and the editor and author of the first four volumes of the series The Ethnography of the Hungarian People (A magyarság néprajza). His work is characterized by extraordinary thoroughness and commitment to material ethnography. On the basis of all this we might think that Zsigmond Bátky was committed to a Volkskunde-type ethnography. This is not quite true. The Ethnography of the Hungarian People (despite its title) is a work of a comparative nature that deals with the other ethnic groups of the Carpathian Basin in detail, providing a perspective about the culture of other interacting European peoples. In the extracts from $A$ Guide, a manual of methodology-defining material ethnography, we see that its author defined his profession explicitly 
as comparative ethnography in taking the stance that there is only one kind of international cultural research which, therefore, can only be pursued comparatively.

Zsigmond Bátky - A Guide to Setting Up Ethnographic Museums. Excerpts from the introduction. ${ }^{65}$

\section{A short history of ethnography, its categories, method, and auxiliary disciplines}

"Ethnography or ethnology, ${ }^{66}$ in its general interpretation, is a very modern science. As [with] all new disciplines, ethnography also had to go through a long process of development until its subject reached its present definition. [...] We cannot omit to mention here the name of the German Adolf Bastian who, during an exceptionally long life, worked the most for ethnology, and whose travels around the world (which surpassed those of every one of his contemporaries) brought the Museum of Ethnography in Berlin, the greatest and widely imitated institute of its kind, into being. It was due to his unmatched activity that extensive work began worldwide in the spacious field of ethnology. It is suffice to say, briefly, that his appearance marked the beginning of an era in the history of ethnology, and that through his work in sociology and psychology he deepened the new science, elaborating its hitherto unstable goal and method, and marked the place of ethnology in the academy of disciplines.

Thus, he effectively became its founder. According to his teaching, the ultimate goal of ethnology or ethnography (now called by two names) is to make us acquainted with humanity's development in its atoms and at different stages of its culture. The former can be achieved through work aimed at introducing every kind of humanity on earth, that is, describing them as, for example, descriptive geography describes the earth (its individual countries, etc.) This, then, becomes descriptive ethnography. It is also necessary to compare different stages of development by different peoples once we get to comparative ethnography, i.e. ethnography. As the final cumulative result of this work, we shall know the different stages as single moments of one coherent spiritual process, or, in other words, we shall find the evolution of human awareness and intelligence by humanity recognized as one organic whole. The less strictly defined kind of ethnography, which can also be called (not very suitably) the study of peoples, discusses all the peoples of our earth, both natural and culture

${ }^{65}$ Zsigmond Bátky (1906) 1994: A Guide to Setting Up Ethnographic Museums. (Útmutató néprajzi múzeumok szervezéséhez.) Budapest: Ethnographical Museum pp. 1-27.

66 In Hungarian terminology, "ethnography" is used for ethnology, ethnography, and even folklore (note by Zsigmond Bátky) 
groups, in relation to each other, and mostly from the vantage point of geography and natural science.

Ethnography, therefore, does not regard man as a solitary individual, does not discuss his physical makeup, his lifestyle, etc. but regards him as the creature and member of social groups (family, tribe, nation), for it has become plain that it is only in these contexts that man is able to fulfil his prescribed destiny. Whoever wants to learn about these things, however, will have to concern themselves with the individual man both from a physical and a psychological aspect. Thus we arrive at physical anthropology, a basis of ethnography, an exclusively anatomical discipline which discusses man (the man of today and the extinct race equally) as a singular, natural being. Similarities and differences define the individual human races. Ancient history or prehistory is closely connected to anthropology. Völkerpsychologie and comparative linguistics are also mighty assistants to ethnology in solving its above outlined task. So is a new discipline which examines man in his relation to his physical environment, i.e. anthropogeography. Another new branch of ethnography, concerned with the primitive spiritual traditions of different peoples and their spiritual expressions (customs, beliefs, etc.) yields valuable information for Völkerpsychologie.

Ethnography, again, briefly, is a purely empirical discipline, based on actual geographical and ethnographic facts, refusing all theoretical speculations. Owing to the fact that it is concerned with the situation of natural or savage peoples, i.e. the beginning and the primitive forms of human culture and development, it was able to give new and surer points of referral to many independent disciplines which have been recognized as related to ethnography.

Three disciplines provide the basis of comparative ethnography: sociology, economics, and the study of culture. The first one is concerned with the origin, forms, and life management of human societies; the second with the moments requisite for man's existence and sustenance (culture plants, animals, industry, trade, forms of economy and their fundaments); finally, the third one, a great discipline which directly affects us, takes as the object of its scrutiny the composition of humankind's spiritual and material culture (natural resources, technology, tools, clothing, etc.; religion, art, science). Let me remark here that spiritual and material cultural assemblies cannot be strictly separated from each other.

This latter discipline affects us directly since it leads on to museums of ethnography in which the assembly of material cultural goods of mankind is gathered. We have touched upon the fact that ethnography was started with the study of savage peoples, which we accept as more or less as a matter of course. We will also regard it as a matter of course that our interest in ethnographic objects was first aroused by exotic objects of natural science, especially by those of savages. Collection was first motivated by mere curiosity, then it became more conscious, albeit restricted to a small circle of individual peoples. Later, collection was extended to all natural 
peoples with great eagerness. This eagerness started after Bastian's appearance had made it clear that the genus human formed one unit from a spiritual as well as a physical aspect, its culture being the result of a shared human consciousness showing differences in gradation, not in essence, etc. This was borne out of tangible objects of the most diverse peoples'. The purpose of these museums was to display the present more recent material culture of the different peoples of our earth in all its colorful diversity, grouped together according to geographical-ethnographic aspects. Culture, however, as it has become clear, is not tied to peoples, but spreads over to other groups from certain radiation points. Peoples are only temporary transmitters of certain phases of human cultural development, and therefore, it is necessary to focus on deepening the historical aspect of further collection works and research. This system of ethnographic divisions cannot stop here: museums called museums of ethnography today will, together with other collections, form museums which, covering the entire globe, illustrate the cultural development of all humanity in its natural stages; in a word, it will become a comprehensive museum of the history of civilization.

With the birth of Darwinism and the increase of descriptive natural sciences, came an interest in savage peoples (wrongly called people without history by a historical concept getting more and more outdated). This interest in "savage" people held minds captive for a long time, which became detrimental to the idea of knowing ones culture before another's (know thyself). In other words, we were prevented from extending the ethnological research already tried on natural peoples to ourselves.

This seems all the more puzzling to us today, since interest in antiquities has been universal for a long time, with huge archaeological collections formed not only from European cultural assemblies, but also from material outside Europe. These collections are practically the ethnographic collections of peoples of the long past, and today's ethnographic collections are, archaeological museums of the present. It was only after some time that we came to realize the fact, that just as in all manifestations of human awareness, we also show all those primitive features that so-called savages do; there are layers in our societies which occupy the same cultural niveau as natural peoples, or as those of our forebears did who left our so-called antiquities behind. This approach was brought to the surface primarily by the probing of comparative psychological-folkloristic research, but later it was also reinforced by the examination of material culture. Comparison with archaeological finds yielded an especially high amount of correspondences (analogies). Hungarian or national museums of ethnography owe their existence to these aspects, to our desire to learn about the organic development of our own culture. Their true significance will be appreciated only by the coming age. [...]"

"This process of development was also followed by the department of ethnography of the Hungarian National Museum. Following foreign examples, not counting Antal Reguly's older, modest Siberian collection, the department focused 
first on people overseas, more specifically East-Asia (Indochina, China, Japan, Borneo). [...] For a while, the museum was enriched only by the home visits of some of our world traveler compatriots, but later it started to come on in leaps and bounds. It should be noted here that beside the goal of collecting, shared by other European museums of ethnography, one specifically Hungarian aspect also contributed to the growth of our department, namely, the thorough geographical scrutiny of ethnic groups related to Hungarians.

A purposeful effort from the start, this scrutiny was a shared pursuit with historical linguistics, and due to the size of its material part, it has been elevated to the rank of a sub-department on its own right. [...]

Should anybody ask what the point of this collection is, anybody can answer that on a smaller scale, it is the same as that of an ethnographic museum encompassing the entire world: namely, to display the cultural wealth of all peoples and social classes dwelling in this country, occupying different levels of cultural development, as they are at present and, as far as possible, as they used to be in the past. [...] Our reflections of the past would go back too far, even if we restricted ourselves to the explication of those aspects which affect the new and, true national science which is yet to unfold from this collection later. What we owe to these collections by virtue of knowing ourselves, our past, our culture, abilities, individual characters, etc., and through the expansion of the national self-awareness that comes from these, we won't really feel it until these treasures, disappear forever, or when we think about what our national civilization lost because our forefathers did not think of collecting these only a hundred or more years ago. What treasure has sunk into eternal darkness, and we, with aching hearts, have to see that in the land of Hungarian ethnography, we are walking among ruins, albeit rich ruins compared to those of other nations. Nevertheless, we can see that the loss of one of our ethnic features which, our intimations tell us, was our own national property (habit of dress, custom, etc.) creates universal pain in the nation's sentiment, and this pain is palpable in every walk of our social life and literature. But, I ask, is our social development not heading in a direction which will inexorably, peremptorily, demand that we seriously engage with the people hitherto so little appreciated and, we may admit, regarded from a naïve perspective in professional studies until this day?"

\section{Some Characteristics of Contemporary Ethnography}

Both cultural anthropology and ethnography have gone through great changes during the long century that has passed by since the turn of the twentieth century. Of the two disciplines, cultural anthropology has completed a longer journey as it has transcended its ethnocentric slant, started using fieldwork, and embraced the fruitful effect of associated disciplines (structuralism, the postmodern, etc.) 
Ethnography has also changed a lot. A desire to confront the past and the demand for paradigm change within the discipline became especially strong in post-war Germany and Scandinavia. Nevertheless, special features that existed from the beginning have certainly remained in place, and these signal its palpable differences from anthropology or sociology. In what follows, we emphasize some distinctive features which differentiate contemporary ethnography from anthropology.

The purpose of a simplified description is to give interested students/ laypeople a "first impression" of the issue, but we ask the reader to bear in mind that this impression is a superficial one. It is not the purpose of this volume on anthropology to give a thorough introduction to ethnography, although some books useful for going further into the subject are recommended at the end of this chapter.

\section{Fieldwork}

Like cultural anthropology, but unlike sociology, ethnography regards the collection of first-hand data (i.e. fieldwork), as very important. During fieldwork, the researcher meets the people they are studying face to face. Ethnographic fieldwork, however, unlike cultural anthropology, does not base research on the participant's observations, but prefers to use other techniques of data collection as well. Ethnographic fieldwork is often called a "collection" or "collecting expedition," while the interviewee is called a "transmitter of data," which implies that the main goal is the collection of results (i.e. of ethnographic data), not participation.

\section{The branches of ethnography}

Very early on, two directions of research diverged in ethnography: material ethnography, and folkloristics. Material ethnography (also called ergology after the French and German example) is concerned with the material objects of culture and the technology with which they were made, including, at times, the research of related customs, religious, and economics factors. Folklore indicates the spiritual products of the ethnic group in question. According to the Hungarian Lexicon of Ethnography, three major areas of folklore have been formed in the Hungarian ethnographic research tradition:

- the folklore of everyday life (the most broadly interpreted area of customs);

- artistic genres (folk poetry, ornamentative arts, and dance, collectively called folk art), and

- superstitions, religious ideas and systems, value judgments. 
In ethnography, folkloristics and ergology are significantly isolated from each other, even on an institutional level: they have their own departments, conferences, etc. Cultural anthropology, in contrast, professes a holistic approach according to which the material and spiritual aspects of culture are tightly connected, thus this discipline does not see a reason for the institutional severance of research projects related to spiritual or material subjects.

In Hungary - beside folkloristics and material ethnography -, ethnology was present as a third branch for a long time. The term "ethnology" - of French origin - was used to refer to ethnography, or, in present-day terms, cultural anthropology.

\section{Auxiliary disciplines of ethnography}

Teaching and practicing museology is part of training in ethnography. This means that ethnographers are required to be able to take care of a museum collection. This undoubtedly useful skill is mostly absent from training programs in cultural anthropology.

Ethnographers often call museology an auxiliary discipline (for it is there to assist them in their work), just as with many other disciplines on the margins of ethnography, their names all starting with the prefix ethno, such as ethnomusicology, ethnolinguistics, ethnobotanics, etc. In cultural anthropology, interdisciplinary areas are not called auxiliary disciplines, for that would indicate that a researcher approached the associated discipline from their own perspective - similarly to the way ethnocentric approaches also strive to understand foreign cultures in comparison with their own.

\section{Value-Centredness}

I shall attempt to elucidate the concept of "value-centredness" with a personal story. I arrived in Ecuador as a student of anthropology in 1993 to do research on indigenous settlements around Otavalo. So, I joined a company of musicians, believing that this would help me delve into deeper layers of indigenous culture. During fieldwork, I slowly progressed beyond simpler tunes sold on tapes to the more archaic melodies played on harp, then on to very simple communal tunes. An exhibition was organized from the material, with these tunes blaring forth from the corners of the room. Because of the tunes' ear-splitting 
monotony, the elderly ladies who were "guarding" the room had to be relieved from their unpleasant posts one by one.

Finally, after spending months in the field, musical research led me to an old shaman living in a settlement far away. He played a flute made of condor bone, or, to be precise, he didn't play it but rather used it as a therapeutic instrument. Immense sacral value is attributed to the flute, which is why Spanish colonizers forbade its use, and it vanished from many areas of the Andes. I myself met a Peruvian archaeologist in Cusco who reacted with incredulity (disbelief, actually) to hearing that not far away, among the mountains of Ecuador, this flute (of which type he only knew of some dating from the eighteenth century) was still being used as a form of therapy. His incredulity, for me, proved that at the end of my exploration, I had happened upon a truly valuable ethnographic find.

One year later, I was studying the anthropology of the Andes in Paris. My instructor in ethnomusicology, Rosalia Martinez, worked on tunes from Bolivia, but her approach differed from mine: she analyzed tunes on tapes bought on markets. The tapes contained folk music with electronic instrumentation. I was astonished: for me, this electric sound meant the lowest level of folk music; under no circumstances would I have wasted time on it on the field. I believed that the folk music I explored at a later stage of my fieldwork (the harp music, and particularly the condor bone flute) represented a much more valuable musical category. During the one-semester course, however, we slowly learned to differentiate between the different musical categories of the electric folk of the Andes (indigenous, Baroque, and contemporary) and their social functions. By the end of the semester, I acknowledged that, for an anthropologist, contemporary, modern folk music as a research subject could be just as acceptable as a (more) archaic one. 


\section{CULTURAL RELATIVISM}

\section{Introduction}

The appearance of cultural relativism, linked to the work of Franz Boas, constitutes a turning point in cultural anthropology. Its significance is also marked by the fact that in the syllabi of most anthropological studies worldwide, the appearance of Franz Boas - or more specifically, the foundation of the cultural anthropology department of Columbia University (1896) and the 1911 edition of The Mind of Primitive Man ${ }^{67}$ - mark the creation of cultural anthropology as a discipline. ${ }^{68}$ The reason the authors of this book consider the oeuvre of Franz Boas exceptional is not the fact that he preceded others, since we have seen in previous chapters that the different Western and Central European schools of cultural research emerged before American cultural relativism. Instead, we underline the fact that Boas was able to form schools, thanks to which cultural anthropology grew into one of the most important areas of social science schools in the United States and worldwide; on the other hand, we also emphasize that he declared and successfully represented the view that humanity has common roots and its cultures are all equal.

To make the significance of Boas' emergence clearer, let us return for a moment to the nineteenth-century concept of culture, influenced by evolutionary theories. As a reminder: the spirit of the age and cultural research were both grounded on a platform of linear evolution, and the assumption that different cultures (whether 'primitive' cultures excavated by archeologists, or those described by ethnographers) basically move in one direction, with the ultimate goal being a culture represented by the civilized countries of the world, with all their peculiar social and technical achievements, such as the telegraph, machines, railways, a health service, monogamy, alphabetical writing, etc.

Needless to say, the evolutionary 'ranking' involved first and last place as well. One of the ethnic groups considered 'the most primitive' (that is, the most ancient or least developed) was the Inuit - or to use the contemporary word, Eskimo. Europeans took the name Eskimo from their nearest neighbors, the Algonquian Indians living in the territory of what is now Canada; in the

\footnotetext{
Boas, Franz 1911: The Mind of Primitive Man. New York: The Macmillan Company.

${ }^{68}$ Ember, Carol R.; Melvin Ember; Peter N. Peregrine 2005: Anthropology, Upper Saddle River, N. J.: Pearson/Prentice Hall. Kottak, Conrad Phillip 2010: Cultural anthropology: appreciating cultural diversity. Boston: McGraw-Hill. Rosman, Abraham; Paula C. Rubel; Maxine Weisgrau 2009: The tapestry of culture: an introduction to cultural anthropology. Lanham: AltaMira Press.
} 
language of Cree Indians, Eskimo means 'they who eat raw fish' and it referred to the fact that the Indians deeply despised their Northern neighbors for eating frozen fish and meat. The name the Eskimos use for themselves means man (inuk = man, inuit $=$ those with two legs [men]).

The Inuit were not only bullied by Algonquians, but they were also the target of the bad jokes of the so-called civilized nations. In Russian, for instance, the Chukchis ${ }^{69}$ are still the targets of such jokes, in the same way the French speak of the Belgians, or the Hungarians about policemen. Jokes about Eskimos were so common around the turn of the century that a few of the innocent ones became proverbs in Hungarian: for example: many Eskimos, few seals, or the 'Eskimo wisdom' never drink yellow snow.

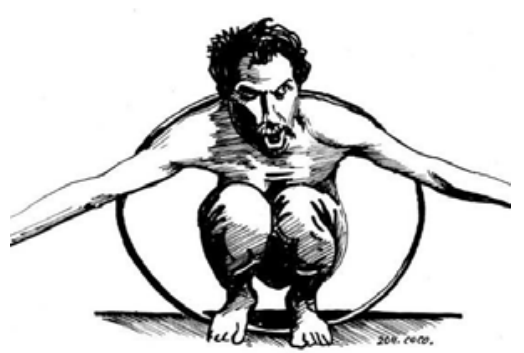

The Inuit were well-placed to become targets for the irony of the contemporary cultivated world because their culture lacked several technical achievements considered fundamental, such as nails, wheels, houses, and beds. They had never heard of yarn, so they did not even know the most elementary forms of weaving. Since they did not use any metals (at least before their contact with white men), their culture was 'rightly' called Stone Age, although they essentially used animal materials, bones, skin and sinews.

\section{Franz Boas' Inuit experiences (1883-1884)}

Boas was born in Germany (Westphalia), and studied physics, chemistry, and geography at the universities of Heidelberg, Bonn, and Kiel, and regularly played sports (athletics). He was influenced by the idealistic image of the 'savage' in German romanticism that attributed positive traits to most ethnic groups considered exotic, such as liberty, physical strength, and honesty.

1882-83 was declared the international year of the polar circle, and a German research station was established on Baffin Island. The researchers at the station sent many reports home about the customs of local Eskimos, among others. The reports captured the attention of young Boas who was studying geography at the time in Kiel. Boas was interested in the relationship between subjective experience and the objective world. Having read the articles on the

${ }^{69}$ Chukchis are indigenous inhabitants of the Chukchi Peninsula and they are often (mistakenly) called Siberian Eskimos. 
way of life and wanderings of Eskimos, he decided that many of his questions would be answered by a one-year geographical-ethnographical period of field work on Baffin Island. He and his assistant, Wilhelm Weike, boarded the ship Germania (on its way to take the polar researchers home) in June 1883.

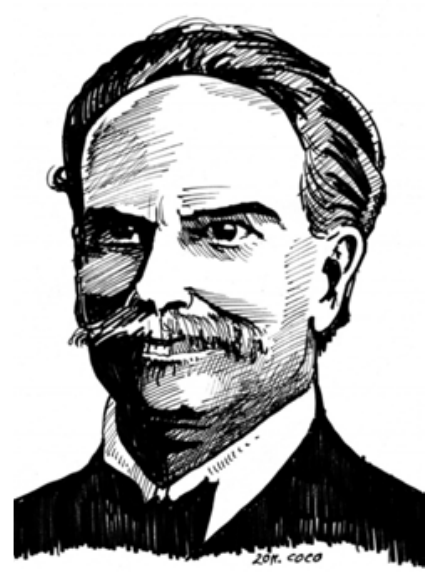

Franz Boas

(1858-1942)

Boas prepared for the trip both scientifically and corporally, since one year in the polar cold - extreme conditions for a European - promised to be a difficult task.

At the beginning, Boas stayed in close proximity to the settlements of hunters and merchants, whilst gradually getting used to his independence. He ventured on the first longer journey a few months later when he visited several Inuit settlements on Baffin Island. During the long journeys between two communities, he had to take care of himself on his own.

In the winter of 1883, Boas and his assistant lost their way in the Polar night. They walked for more than a day in $-46{ }^{\circ} \mathrm{C}$ cold, and the soft, deep snow made walking extremely difficult. He was reaching his end when some Eskimos invited him into their house. During his stay with them, Boas was able to study Eskimo culture more closely than anybody before him. Since he was always thinking of his bride (left behind in Germany), to posterity's great fortune, he kept a letter-diary that reported the days spent there much more profoundly than the usual journals used in field work.

Boas' food and home were supplied by the Eskimos, and what is more, they helped him learn to orient himself. His hosts invited him to accompany them on their hunting trips and (since they knew every inch of the place) helped him create and/or check maps.

During the year spent among the Eskimos of Baffin Island, Boas reevaluated his image of human culture. He learned that his hosts were not 'primitive' the way contemporaries had supposed them to be - on the contrary, he found that their culture represented the highest level of 'civilization' in the harsh circumstances of arctic life. He gave two 'examples' of this. The first was he himself: Boas had good reason to suppose that he was a man of extraordinary abilities, since he had set out on his journey after thorough physical and intellectual preparation. His education and preparedness also elevated him above his contemporaries: at the age of 24 , he was familiar with several disciplines and had a doctorate in physics. However, not even his 
European culture and the best technical gear of his time would have kept him alive in the circumstances among which Eskimos spend their entire lives. What is more, Eskimos set out on much longer expeditions every winter to find prey, yet they even had the strength to accommodate and feed him, the European researcher. He had to admit that Eskimos had better physical and even technical gear than he did; for instance, the Eskimo 'gaiters' (hip-high boots) are extremely appropriate for walking in the snow for hours or days on end while minimizing the danger of freezing - European culture has still not produced similar boots. Here is a quote from Boas' field diary:

'I often ask myself what advantages our 'good society' possesses over that of the 'savages' and find, the more I see of their customs, that we have no right to look down upon them... We have no right to blame them for their forms and superstitions which may seem ridiculous to us. We 'highly educated people' are much worse, relatively speaking.'

The other form of 'proof' that probably made Boas think was the assumed Viking origins of the Inuit of Greenland. In 1000 A.D. in Greenland, Viking settlements were created by Erik the Red, and these survived until the fifteenth century (until the cooling of the climate). These Greenland settlements formed a part of Christian Europe: their inhabitants maintained commercial relations with their homeland, Norway, and furthermore, they acknowledged the formal rule of the Norwegian king in 1261; their bishops (who always arrived from Europe) were appointed by the Pope, while the settlers supported European Christianity with a Church tax and other gifts (they sent polar bear skins, for instance, to help the armies in the Holy Land during the crusade of 1262).

We still do not know what happened to the Vikings after that. There are three realistic hypotheses: they left the island, they starved to death, or they adopted the Inuit way of life - there were probably instances of all three events. ${ }^{70}$ One thing was already sure at the turn of the century: only those Vikings could have survived the cooling on the island who had become Inuit, and had assimilated into their groups. If there is a grain of truth in the hypothesis of the 'survival of the fittest', or in the ethnocentric declaration that a more developed culture assimilates a less developed one, in this case, Inuit culture proved more developed than the Germanic one.

Inuit culture has other original features that make it the 'most developed' culture in the given natural and social circumstances. One example is the

70 Diamond, Jared 2005: Collapse: How Societies Choose to Fail or Succeed. Viking Press. See also: Alfred W. Crosby 1986, 1993: Ecological Imperialism. The Biological Expansion of Europe, 9001900. Cambridge MA: University Press. 
igloo, the house that may easily be built anywhere during hunting trips. The form of the igloo inspired the modern tents that we use ourselves when camping. The other example is dressing. Even though Eskimos did not know weaving and spinning, they became masters of tailoring way before it arose in European culture. They tailored animal skins and sewed them so precisely with 'thread' made from animal sinews that their clothes did not even get wet when they spent time in icy water. Their hunting for whales demonstrates the complicated elements of Inuit technology (see boxed text). The intricate world of Inuit legends fascinated Franz Boas even more than their objects. According to his letter-diaries, he listened to the tales told by his local friends for long hours every night, and he could only compare their interrelated system to Greek mythology.

How the Inuit hunted for Whales

By Ádám Hoffer

Humanity tried to populate the territory of Greenland in several waves. According to archeological data, Greenland settlers died one after the other, while their members often did not even meet those who came after them. The last colonizers of Greenland (and the first about whom we have written sources) were the Vikings, who - according to the saga of Erik the Red - settled in two Southern fjords on Green Island in 1000 A. D. and primarily kept livestock in barns. However, they did not sufficiently exploit the possibilities for hunting in the polar land. The cooling of the climate and regular attacks by the Inuit both contributed to their extinction.

The Inuit arrived to the Southern shores of Greenland from the North, from even colder regions. Their survival was to a large part ensured in this bleak land by the fact that they learned to overcome the largest animal on Earth, the whale. According to Jared Diamond's description: 'the Inuit represented the climax of thousands of years of cultural developments by Arctic peoples learning to master Arctic conditions. So, Greenland has little wood available for building, heating, or illuminating houses during the months of Arctic winter darkness? That was no problem for the Inuit: they built igloos for winter housing out of snow, and they burned whale and seal blubber both for fuel and for lighting lamps. Little wood available to build boats? Again, that was no problem for the Inuit: they stretched sealskins over frameworks to 
build kayaks, as well as to make their boats called umiaqs big enough to take out into unprotected waters for hunting whales.' ${ }^{* 1}$

The Eskimos were fully aware of the movements of wandering whales. $^{* 2}$ When the gigantic mammals swam near the shore, the hunters were sitting in boats, waiting for them to come up for air. They had to use this moment to throw their harpoons. To this end, they used a special weapon, a pipe-shaped harpoon. When the spike of the harpoon went under the skin, the whale started to throw itself about and tried to seek shelter under the water. The Eskimos would not let their prey escape so easily, so they came up with different solutions.

* Diamond, Jared 2005: Collapse: How Societies Choose to Fail or Succeed. Viking Press.

** Douglas, Marianne S. V. et al. 2004: Prehistoric Inuit whalers affected Arctic freshwater ecosystems. In: Proceedings of the National Academy of Sciences of the United States of America, 101(6), pp. 1613-1617.

The spike of the harpoon was carved in pieces, so it stuck under the skin when it hit the body. With the help of a clever clip, the handle could be detached with one single movement and the hunter could pull it back to avoid the whale drowning the whole boat. The spike was equipped with a ball filled with air and a long rope which prevented the wounded animal from escaping by going under the water, and floating buoys exhausted it. When it came up again, more harpoons were thrown, and this continued until the whale was completely exhausted. Then it received the sockdolager with a lance.

Not only was the meat of the whale used: houses and boats were built from the skin and bones, while the blubber was used for insulation and heating.

\section{Historical particularism}

When his arctic mission came to an end, Franz Boas worked for a while in the Berlin Ethnographic Museum under the direction of Adolf Bastian, then moved with his wife to the United States where he first worked in the business world, then in science. As a researcher of culture, he primarily worked among Kwakiutl. He was appointed university professor at the University of Columbia in New York in 1899. His field work among the Inuit and Kwakiutls strengthened his persuasion that the widespread understanding of the development of humanity was fundamentally wrong.

In 1910-11, Franz Boas gave a series of lectures entitled The Mind of Primitive Man; it is in these lectures that he laid the foundations of cultural 
relativism and historical particularism. The latter series were later published in a book that became highly influential at the time; when Hitler came into power, it was banned in Germany because of its antiracist views. The following quotations are from Chapter 8 of the book. ${ }^{71}$ We first show how Franz Boas challenged Aryan theory, or, more generally, the linking of physical and intellectual cultural traits.

'...The bodily form cannot be considered as absolutely stable: physiological, mental and social functions are highly variable, being dependent upon external conditions, so that an intimate relation between race and culture does not seem plausible. It remains to investigate this problem from another angle, by means of an inquiry which would show whether types, languages and cultures are so intimately connected that each human race is characterized by a certain combination of physical type, language and culture. [...]

At the present period we may observe many cases in which a complete change of language and culture takes place without a corresponding change in physical type. This is true, for instance, among the North American Negroes, a people by descent largely African; in culture and language, however, essentially European. [...] Other cases may be adduced in which it can be shown that a people has retained its language while undergoing material changes in blood and culture, or in both. As an example of this may be mentioned the Magyar of Europe, who have retained their language, but have become mixed with people speaking Indo-European languages, and who have adopted European culture. [...]

These two phenomena - retention of type with change of language, and retention of language with change of type - apparently opposed to each other often go hand in hand. An example is the distribution of Arabs along the north coast of Africa. On the whole, the Arab element has retained its language; but at the same time intermarriages with the native races were common, so that the descendants of the Arabs have retained their old language and have changed their type. On the other hand, the natives have to a certain extent given up their own languages, but have continued to intermarry among themselves, and have thus preserved their type. [...] Cases of complete assimilation without any mixture of the people involved seem to be rare, if not entirely absent. [...]

It is obvious, therefore, that attempts to classify mankind, based on the present distribution of type, language and culture, must lead to different results, according to the point of view taken; that a classification based primarily on type alone will lead to a system which represents more or less accurately the blood-relationships of the people; but these do not need to coincide with their cultural relationships. In the same way classifications based on language and culture do not need to coincide with a biological classification.

${ }^{71}$ Boas, Franz 1911: The Mind of Primitive Man. New York: The MacMillan Company, Chapter 8. 
If this be true, then a problem like the Aryan problem does not exist, because it relates to the history of the Aryan languages; and the assumption that a certain definite people whose members have always been related by blood must have been the carriers of this language throughout history; and the other assumption, that a certain cultural type must have always belonged to peoples speaking Aryan languages are purely arbitrary ones, and not in accord with the observed facts.'

According to the linear theories of evolution widely accepted in the nineteenth century, humanity had reached different levels of development in different areas of the world, but thanks to development, all cultures were heading in one direction - that of the most developed civilizations known at the time (European culture).

In time In space

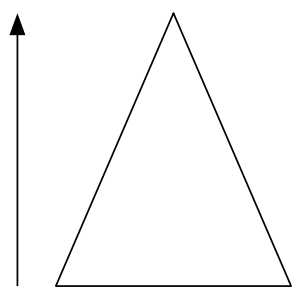

Evolutionary 'pyramid'

Boas described a process that contrasted with the perspective about evolution: on the basis of his (and others') physical anthropological research, he concluded that humanity comes from common stock (one branch), and maybe from a common ancestor; which also means that ancient man must once have lived in one single region of the Earth. (His views are reinforced by modern genetic research [see boxed text]). 
Time-Travel in Genetics - In Search of the Origin of Human Populations

Then God said: Let us make mankind in our image...

So God created man in His own image; in the image of God He created him; male and female He created them.

Genesis 1:26,2*1

The myth of creation forms the basis of all world religions. It provides an answer to the question raised by every child: where do we come from, and what is the reason for our existence?

This is an edited extract of a lecture with the same title given at Mindentudás Egyeteme on 8 March 2004. The whole lecture may be downloaded at http://www. mindentudas.hu/ rasko/20040308rasko1.html (downloaded on: 2010. 07. 13.).

It does not explain, however, the reason for the unbelievable diversity we observe in the passers-by of any big city. There must be a genetic explanation for the physical differences between people, but we know now that these traits are formed by the shared effect of several genes.

Mitochondrial DNA is used in the study of the inheritance of maternal traits, while the father's influence may be tracked through an examination of Y-chromosomal DNA. Both markers similarly explain how the world became populated, and they have helped determine the origins of several ethnic groups.

If we look at the event calendar that shows (on the basis of Mitochondrial DNA) how modern humans populated the Earth, we see that the first wave of individuals arrived from Africa to the Near East 80-65,000 years ago, people got to Australia on the seashore 'highway' about 60,000 years ago, the first wave of settlers arrived in South East Asia and Europe 40,000 years ago, while the New World was populated through the then-usable Bering Strait 15-10,000 years ago. According to genetic data, modern non-African ethnic groups all originate from about 10-20,000 African individuals.

In relation to studies of the origins of man, it is very important to understand that the $Y$ chromosome carries the same story as mtDNA, thus men and women share the same genetic story. Adam met Eve.

Classical and molecular genetic methods both prove that there are no genetically 'pure' populations. More than $80 \%$ of the difference 
between people may be attributed to individual differences, while only $10 \%$ of the latter are caused by genetic differences. Such differences account for e.g. the color of one's skin.

Although the pigmentation of the skin is regulated by several genes, the white skin and red hair observed in the English and the Irish is related to a variant of a hormone-receptor gene (melanocytestimulating hormone receptor). The African population carries the ancient variant of this gene, while non-Africans have both the ancient and newer variants. The variant linked to dark skin represented an evolutionary advantage in Africa because of higher levels of ultraviolet radiation, while outside Africa there was no selection pressure for this gene; what is more, other variants may have represented an evolutionary advantage.

Throughout history, small groups of humanity left their homelands for remote regions of the Earth and adapted to different circumstances in different ways. In a desert, the appropriate form of adaptation is for the ethnic group to learn to save water and not to overpopulate. Those living in the fertile valleys of rivers did not need this knowledge - on the contrary, the more populous the group, the better they could defend themselves and the more easily they could share work. Neither adaptation technique is 'better' or 'worse' than the other: agricultural cultures could not survive in the desert or in arctic regions, and vice versa. Using a social Darwinist argument, we may say that all contemporary cultures represent the highest level of 'civilization' in their own natural and social circumstances, otherwise the given culture would have fallen victim to selection (in the case of cultures, this means extinction, integration, and/or assimilation).

Lajos Bíró, the Hungarian researcher of Papua Land, defended his native friends by saying that they deserved empathy, and even respect, as representatives of the infancy of our own culture. He also explained how 'being educated' is a relative concept - the knowledge of the Papuans is worth more in their circumstances than the knowledge associated with European culture:

'I spent seven years with peoples that still live in the authentic Stone Age, in a cultural era that has been non-existent in our region for several thousand years; [...] they are living examples of the lives of our ancestors. [...] We may assume that our 333rd forefather of our Stone Age was as educated as a Tamol of the modern Stone Age. [...] Education is in any case a very relative concept. If a Tamol visited us, he would 
be uneducated as he would not know our little social habits, whereas among them, we are uneducated for the same reason. ${ }^{72}$

What Franz Boas made clear was that neither Papuans nor other peoples outside Europe represent an early phase of our culture, but they rather represent completely different directions of development. Papuans and amidst their own natural and social circumstances - all other human cultures of our times exist at the 'most developed' level.

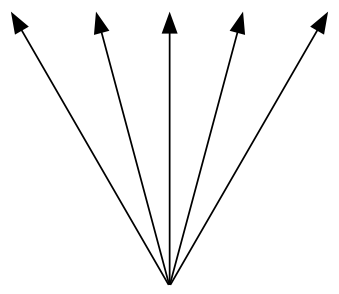

Reversed evolutionary pyramid - based on Franz Boas' thoughts

Humanity originated from a common ancestor, but followed different paths of development; all human cultures of our times may be considered to be at the 'most developed' level amidst their own natural and social circumstances.

The term historical particularism refers to the methodological and ethical attitude according to which the culture of each ethnic group must be interpreted on the basis of its own natural and environmental circumstances. The concept of historical particularism was in radical opposition to the accepted practice of contemporary cultural research, the comparative method. (The following quotations are from the same source as the previous one.)

'We must once again stress one of the main aims of anthropological research. We agree that there are certain laws regulating the growth of human culture, and our aim is to explore them. The aim of our research is to discover the processes that directed the formation of certain levels of culture. Customs and beliefs are not the ultimate goals of our research in themselves. We would like to know why these customs and beliefs exist - in other words, we are trying to learn the history of their development. Nowadays, the most common method of such research is to compare the different versions of these customs and beliefs and to try to find the shared psychological reason behind all of them. I explain the fundamental opposition to this method.

72 Lajos Bíró: Fürdőzés a kőkorszakban (Stone Age Bath). In: Tibor Bodrogi (ed.) 1977: 177. (Selected writings of Lajos Bíró. Budapest: Gondolat) 
There is, however, another method, in many ways safer. If we have a closer look at customs on the basis of what consequences they have on the tribe practicing them and we also explore their geographical expansion into neighboring tribes, we almost always have a possibility to relatively precisely find the historical reasons that led to the creation of the customs in question and to the psychological processes having a part in their development. Research carried out with such a method may yield three types of results. It may detect the environmental conditions that created or modified the cultural elements; it may highlight the psychological factors that contributed to the formation of the given culture; or it may show us the consequences of historical links on the growth of culture.

This method provides us with a tool that helps us reconstruct the history of the growth of ideas with much more certainty than the generalizations of the comparative methods would allow. The starting point of the latter will always be a hypothetical way of development whose probability may be judged more or less precisely on the basis of the data studied. However, I have never seen an experiment of greater scale so far that would have tried to prove the truth of a theory by checking it in the light of the now known events of development. The method that starts from a hypothesis is inferior to the one where we explore the real story of a given phenomenon by induction. This latter method is none other than the often despised historical method. Its procedure is of course not the same as in earlier times when the superficial similarity of cultures were considered proofs of the relationship, but it is willing to take into account the results of comparative research. The basis of its use is first of all a well defined geographical region, and comparisons do not extend beyond the borders of the area serving as the basis of research.'

\section{The anthropology of cultural relativism}

Another key concept that may be linked to Franz Boas (even though he never used it) is cultural relativism. Cultural relativism is a principle of the methodology of research that is a consequence of historical particularism: all cultures may be interpreted in their own circumstances, and in relation to those circumstances. In 1887, Boas wrote the following words about the exhibitions of ethnographic museums: 'It is my opinion that the main object of ethnological collections should be the dissemination of the fact that civilization is not something absolute, but that it is relative, and that our ideas and conceptions are true only so far as our civilization goes. ${ }^{73}$

\footnotetext{
${ }^{73}$ Franz Boas 1887: "Museums of Ethnology and their classification" Science 9: 589. In: George W. Stocking Jr. (ed.) 1974: A Franz Boas reader. Chicago: The University of Chicago Press, p. 62.
} 
The term cultural relativism was already being used in the 1920 s and 30 s by Boas' disciples, but as the master himself did not like it, it only spread after 1942, the time of Boas' death. Cultural relativism is one of the basic principles of contemporary anthropology that (despite Boas' intentions) later eras can harmonize with the need for comparison.

Anthropology based on cultural relativism has several peculiarities that distinguish it from the previous, evolutionary approach; below, we give an overview some of these traits.

\section{All cultures are equal:}

As opposed to the anthropologist researchers of the nineteenth century, Boas believed that all cultures, including the civilization that breeds the anthropologist, must be considered equal.

\section{The need for field work:}

The need for field work in cultural anthropology was recognized in the USA and Great Britain at around the same time, in the 1920s. Franz Boas regularly carried out field work himself during his years as a university professor, and being a curator of the American Museum of Natural History and a professor at the University of Columbia at the same time - he often ensured his students the chance to engage in field work within the framework of museum work.

\section{Relationship:}

The relationship between the researcher and those researched became equal, or, more precisely, it started to become more symmetrical, due to the work of Franz Boas. Anthropologists found out only later, however, during the dissolution of colonizing empires, that the intellectuals of countries becoming independent still felt that the situation was unequal: it is always the white man who researches the colored, the educated who researches the uneducated.

Posterity criticizes Franz Boas himself, because in his monograph on the Kwakiutl, published in $1897,{ }^{74}$ he did not designate as a co-author his

\footnotetext{
${ }^{74}$ Boas, Franz 1897: The social organization and the secret societies of the Kwakiutl Indians. Washington.
} 
key informant, the native George Hunt ${ }^{75}$ who carried out methodological collection work commissioned by Boas. We must, however, acknowledge that for the time it was a great step forward that Boas even thanked Hunt for his contribution in the Acknowledgements chapter, and made it clear that Hunt's collection had significantly added to the book.

\section{Not applied science:}

Franz Boas never asked for and never accepted help from colonizing institutions. Although his disciples received important commissions from the American army (Benedict Ruth, for instance, carried out anthropological research on Japanese prisoners of war and of occupied Japan), on the basis of the past century, we can observe that cultural anthropology has served (post)colonial interests less and less.

\section{The anthropologist's mission:}

The appearance of Franz Boas marked a slow turn in cultural anthropological field work: the passion for collection decreased, with anthropologists increasingly collecting not for museums but primarily compiling the cultural heritage of the cultural community living in the field. Researchers are now expected to share experience gathered during field work with the studied cultural group.

According to the mission of action anthropology - which arose at the University of Chicago at the end of the 1940s -, the anthropologist doing field work must explicitly support the culture they study, as their education, knowledge of languages etc., make them better placed to represent the interests of the oppressed than - for example - uneducated Indians who cannot defend their interests.

\footnotetext{
75 Boas' local helper, George Hunt, was not a 'typical Indian'. His mother was Tlingit, his father English, while George Hunt himself grew up among Kwakiutl Indians. See Gmelch, Sharon Bohn 2008: The Tlingit encounter with photography. Philadelphia: University of Pennsylvania Museum of Archaeology and Anthropology, p. 47.
} 


\section{The School of Culture and Personality (USA, 1920-1950)}

Franz Boas wrote relatively little, but as an influential professor he trained a whole group of young anthropologists. Many of his former students pursued scholarly careers, founded university departments and journals, and by the 1940s, students of Boas were a majority in American anthropology. The perspective of Boas and his disciples is qualified as cultural relativism by posterity. This is not a name they used to label themselves. On the one hand, we should not forget that Franz Boas never used the concept cultural relativism (he suggested the term historical particularism), while on the other hand, members of the Boas school did not use this expression to characterize themselves; they labelled their own work with the term 'culture and personality' or 'psychological anthropology' (this is what many textbooks and encyclopedias on anthropology also call them and their field of study).

The present book does not use the adjective psychological in connection with the Boas school for two reasons. One is that not all disciples of Boas considered themselves psychological anthropologists (for instance, Alfred Knoeber became known as an anthropologist and archeologist, and Melville Herskovits as a pioneer of economic anthropology); they all agreed, however, with the principles of historical particularism and cultural relativism. On the other hand, at the same time a psychoanalytical anthropological trend developed in Europe based on Freud, which had few links to the American school; accordingly, we do not use the term psychological anthropology to designate either, to avoid misunderstandings.

The reader may ask why the use of any distinguishing adjectives emerged at all - as in American anthropology. The answer is that, at the time, 'anthropology' primarily meant the social science with an evolutionary perspective that emerged in Great Britain, in sharp contrast to the school founded by Franz Boas. ${ }^{76}$ These days, this situation has fundamentally changed: by 'cultural anthropology' we primarily mean the 'American' school, while we call British anthropology 'social anthropology.' The significance of the school created by Franz Boas lies first of all in the fact that most of his disciples were interested in research and education: they founded a whole series of departments all over the United States and thus contributed to making cultural anthropology one of the most important disciplines - maybe even the most important discipline - of social science in the New World.

\footnotetext{
76 The terms cultural and social anthropology were both created in Great Britain at the beginning of the twentieth century to distinguish between the different trends in anthropology, see: Peter Rivière (ed.) 2007: A History of Oxford Anthropology. Berghahn books, Methodology and History in Anthropology. Franz Boas consistently called his area of interest anthropology.
} 
Rather than reviewing the prolific works of Boas' disciples, I will illustrate the birth of the anthropology of cultural relativism through the oeuvre of three extraordinary scholars, Edward Sapir, Ruth Benedict, and Margaret Mead. ${ }^{77}$

\section{Linking research about culture, linguistics, and psychology - the work of Edward Sapir}

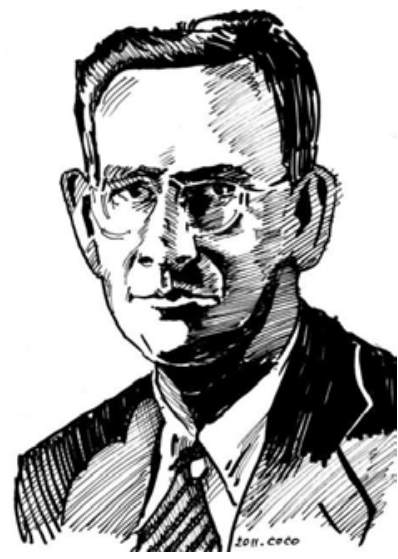

Edward Sapir

(1884-1939)
Edward Sapir was born in New York to a poor family of German-speaking Jewish immigrants, and proved to be so versatile that he contributed to the creation of an artificial language (interlingua), wrote poems, is now considered to be the first professional Canadian anthropologist-museologist, was one of the first professors at the social sciences department of the University of Chicago, and co-founded the cultural anthropology department at Yale with George Peter Murdock.

Edward Sapir was also deeply interested in a newly forming discipline, psychology, and especially in the writings of Carl Gustav Jung; he was especially influenced by the book The Question of Psychological Types. Although Jung spent more and more time in the United States from the 1930s onwards

(in 1938, they both taught at Yale University), Sapir benefited from the fact that he could read Jung's work in its original written language, German. The majority of Boas' disciples could not read Jung in German, thus the source of their information about psychology was primarily Sapir.

Edward Sapir's original degree was in German linguistics; he turned to native American languages that lacked written form due to the influence of his teacher, Boas. Today, we think that linguistics and anthropology are linked in several ways, since culture is usually defined as a complicated system of symbols whose purest form is human language. Edward Sapir played a significant part in the fact that we now think this way because he managed to highlight the importance of language in anthropology. His

77 On the disciples of Boas and the early years of the anthropology of cultural relativism, see for instance: Paul Bohannan; Mark Glazer 1988: High Points in Anthropology. New York. Knopf.

Averkijeva, Julija Pavlovna 1981. North American Indian Studies. Göttingen: Edition Herodot. 
thoughts were further elaborated by his student Benjamin Whorf at the beginning of the 1930s; according to the Sapir-Whorf hypothesis, language does not primarily serve as a means of expression, but for the forming of our thoughts. The following quotations draw attention to the significance of language. ${ }^{78}$

'The value of linguistics for anthropology and culture history has long been recognized. [...] Language is becoming increasingly valuable as a guide to the scientific study of a given culture. In a sense, the network of cultural patterns of a civilization is indexed in the language which expresses that civilization. It is an illusion to think that we can understand the significant outlines of a culture through sheer observation and without the guide of the linguistic symbolism [...]

Language is a guide to 'social reality'. Though language is not ordinarily thought of as of essential interest to the students of social science, it powerfully conditions all our thinking about social problems and processes. Human beings do not live in the objective world alone, nor alone in the world of social activity as ordinarily understood, but are very much at the mercy of the particular language which has become the medium of expression for their society. It is quite an illusion to imagine that one adjusts to reality essentially without the use of language and that language is merely an incidental means of solving specific problems of communication or reflection. The fact of the matter is that the 'real world' is to a large extent unconsciously built up on the language habits of the group.'

\section{Ruth Benedict: the characterology of culture}

Ruth Benedict came from an upper-middle class Protestant, American family. Her hearing was seriously damaged; her disability, however, did not prevent her from pursuing university studies as a woman (which was quite unusual at the time), nor from completing a whole series of long and difficult field work among North American Indians and in Japan after the war. Her talent was soon recognized by Franz Boas and she became one of the first professors at the department.

Benedict was highly influenced (through the mediation of Edward Sapir, Karen Horney, and Abram Kardiner) by contemporary German psychology - more precisely, by the trend of characterology. Characterology was fashionable in the history of ideas in the 1920s, and several complex and simple psychological typologies appeared. Carl Gustav Jung invented the

78 Sapir, Edward 1929: The Status of Linguistics as a Science. Language, 5/4, pp. 207-14. 
words 'introverted' and 'extroverted', which are now used by everyone, whereas the character typology of Ernst Kretschmer distinguished three main types of people: pyknic (short, fat, cheerful), asthenic (tall, with big nose and short chin, introverted) and athletic (strong body and soul).

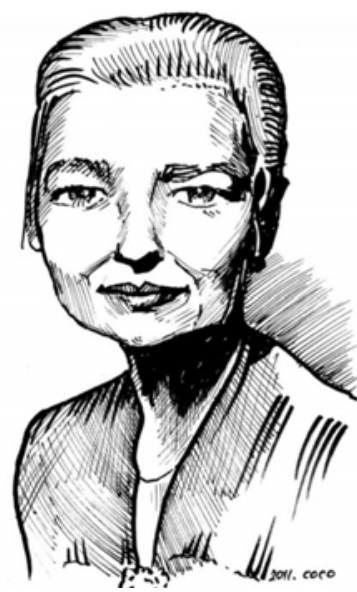

Ruth Benedict (1887-1948)

Before Ruth Benedict published her Patterns of Culture in 1934, she carried out extensive field work among Indians living in the North-American plains, the pueblos of New Mexico, and other native ethnic groups. She spent several months doing intensive field work with all the ethnic groups she describes. On the basis of the information she gathered, she tried to describe the fundamental traits of the given culture from a psychological perspective, mostly by using the concepts 'Apollonian' and 'Dionysian' following Nietzsche. Patterns of Culture may be interpreted as a characterology of American indigenous cultures.

In her book, Benedict often makes generalizing declarations - for instance, that the Kwakiutl are 'megalomaniac', other cultures are 'paranoid', etc. Due to this, many readers consider her book to be racist, even though Ruth Benedict argues for cultural relativism and much of her oeuvre is dedicated to explicitly challenging racial theories. However, according to Benedict's critics, if different Indian tribes and ethnic groups had particular traits, and the differences were so notable that they appeared in psychological characteristics and unique physical anthropological traits, it would take us just one further step to declare our own ethnic group, tribe, or race better than the others. This is why we may assess American psychological anthropology, which merges the ideas of cultural relativism and of contemporary psychology, as an insightful experiment that nevertheless cannot be pursued at present.

During the years of World War II, the government of the United States gave work to several researchers of the social sciences, including anthropologists. Ruth Benedict, who had taken over the department after Franz Boas' death in 1942, participated in many research projects, especially researching the cultures of Romanian, German, Italian, and Japanese prisoners of war. Her Chrysanthemum and the Sword, published in 1946, summarizes her research on Japanese culture. 


\section{Ruth Benedict: Chrysanthemum and the Sword ${ }^{79}$ (extracts)}

Ruth Benedict originally started to work on her book (commissioned by the military, by the Office of War Information) to help America get to know her enemy and achieve victory.

'The Japanese were the most alien enemy the United States had ever fought in an all-out struggle. In no other war with a major foe had it been necessary to take into account such exceedingly different habits of acting and thinking. [...] It made it a major problem in the nature of the enemy. [...] We had to try to understand Japanese habits of thought and emotion and the patterns into which these habits fell.'

Ruth Benedict describes her attitude to the topic and the methodology she used in the first chapter of the book (Assignment: Japan):

'The fact that our two nations were at war inevitably meant, however, a serious disadvantage. It meant that I had to forego the most important technique of the cultural anthropologist: a field trip. [...] At least I did not have to forego the anthropologist's great reliance upon face-to-face contact with the people he is studying. [...] The vast literature on the Japanese and the great number of good Occidental observers who had lived in Japan [...] gave me an advantage. [...] I went to movies, too, which had been written and produced in Japan...'

Thus, Ruth Benedict could not travel to Japan to conduct field work because of the war (she did not speak Japanese, by the way) but in spite of all this, she used all complementary methods to provide a full picture of the Japanese. This method is now called 'studying a culture from a distance'. On the basis of her discussion with Japanese people living in the States, and previous reports, she sought to determine the underlying ideology and patterns in Japanese behavior.

'In anthropological studies of different cultures the distinction between those which rely heavily on shame and those that rely heavily on guilt is an important one. [...] Shame is a reaction to other people's criticism. A man is shamed either by being openly ridiculed and rejected or by fantasying to himself that he has been made ridiculous. In either case it is a potent sanction.'

As Ruth Benedict points out, the desire to fit in is not only valid in the circumstances of war, but is one of the fundamental traits of the Japanese soul:

\footnotetext{
79 Ruth Benedict 1946: Chrysanthemum and the Sword. Boston: Houghton Mifflin. The sources of the citations: pp. 1-4, 5-7.
} 
'The Japanese have always been famous for the pleasure they get from innocent things. [...] But the Japanese ask a great deal of themselves. To avoid the great threats of ostracism and detraction, they must give up personal gratifications they have learned to savor. [...] Those who do respect themselves (jicho) chart their course, not between 'good' and 'evil', but between 'expected man' and 'unexpected man', and sink their own personal demands in the collective 'expectation'. These are the good men who 'know shame (haji)' and are endlessly circumspect. They are the men who bring honor to their families, their villages, and their nations.'

The study also found the answer to a phenomenon thus far considered incomprehensible: that Japanese soldiers who were merciless and fanatical as enemies of war, who fought until their last bullet or their kamikaze suicide, suddenly started loyally serving American interests when they become prisoners of war. The reason is that they tried to become good Americans if they could not be bad Japanese.

\section{The anthropological study of everyday life: Margaret Mead}

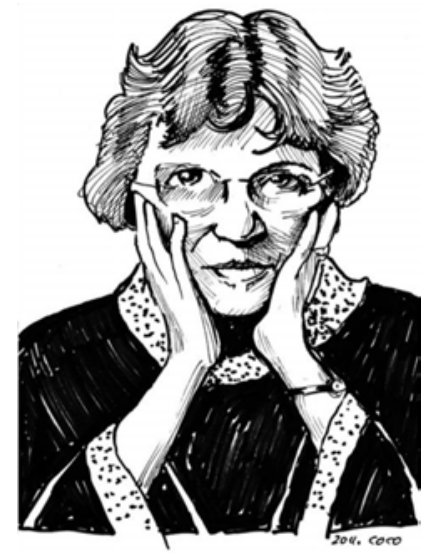

Margaret Mead

(1901-1978)
Margaret Mead came from a poor Quaker family, but made it to university; her career is inseparable from her private life. She conducted the first of her two famous periods of field work in Oceania when she fell in love for the first time, and the second when she was expecting her first child. The astonishing openness of her field work reports made her the most popular anthropologist of her time, and her books are still bestsellers in the United States and in Hungary.

Margaret Mead obtained her degree at Barnard College, then moved to the University of Columbia following the advice of her teacher and close friend, Ruth Benedict. Since Mead - already married at the time - fell in love with Benedict, in 1925-26 she carried out field work on the island of Samoa to try to help her resolve this contradiction. On Samoa, she continued to think about the meaning of a marriage based on love, of why love is important in one's life, and of how this may be harmonized with one's work. At the time, the women of Samoa got married at around the age of 14 . Mead talked to 12-13-year-old girls who 
were awaiting marriage about issues that were important to her at the age of 24-25 (women in the United States also married earlier those days). She was able to talk endlessly about these things during her field work, and her subjects also considered the topic to be an ever important and interesting one. These reports, interviews, and observations led to the publication of her book Coming of Age in Samoa.

This means that Margaret Mead brilliantly put the principle 'openness for openness' - now an important part of the methodology of field work into practice. The principle means that one may gather the same amount of information on others as the amount that we are ready to share ourselves. This is why we must try to choose a research topic we are genuinely interested in: so that we do not tire of it, and so can talk about it sincerely and happily.

All three of Margaret Mead's husbands were anthropologists. During her years of study, she married Luther Cressman (this marriage ended due to the research in Samoa); her second husband was Reo Fortune, with whom she did research in New Guinea between 1931 and 1933; and her third husband was Gregory Bateson. This third marriage was consummated in Singapore in 1936, followed by field work on the island of Bali. They even used a camera to document things - this was a novelty at the time. The research lasted until 1939, when Mead became pregnant and gave birth to a child in New York. The marriage with Bateson ended in 1950. Mead's last partner was Rhoda Metraux, to whom she was connected to both as a romantic partner and a colleague.

In the first months of her pregnancy, Mead had many discussions about motherhood with the native expectant mothers of Bali and the other islands she visited. As an expectant mother, she found natural occasions for making observations and having conversations about expecting a baby.

On the different islands, Margaret Mead received opposing advice about the nurturing of babies. On one island, for instance, she was advised not to let the baby sleep, because if it slept too much, it would not be clever enough. On other islands she was told the exact opposite. Of course, there was no island on which they did not let babies sleep at all, but on some islands cuddles were considered a more important need than sleeping. It was not considered a problem if other children came in and woke a baby up: they were allowed to take the baby into their arms, to kiss and entertain it.

Besides very simple things, Mead also observed that there were great differences not only between nurturing principles, but between other aspects of different cultures. On one island of Oceania, there are cruel headhunters, while on another there are sweet fishermen who welcome visitors with garlands of flowers. Children are raised completely differently in these two places. Mead assumed the existence of a close causal relationship between 
the two factors. In the case of an ethnic group thought to be cannibals, the Mundugumors (in reality they were not cannibals, but simply a pugnacious, temperamental people), Mead traced the characteristics of the adults to the group's principles concerning the raising of children. ${ }^{80}$

'The Mundugumor man-child is born into a hostile world, a world in which most of the members of his own sex will be his enemies, in which his major equipment for success must be a capacity for violence, for seeing and revenging insult, for holding his own safety very lightly and the lives of others even more lightly. From his birth, the stage is set to produce in him this kind of behavior. When a Mundugumor woman tells her husband that she is pregnant, he is not pleased. [...] A man has no heirs, only sons who are hostile rivals by definition, and daughters who, defend them as he will, will eventually be torn from him.'

Besides the Oceanian cultures she analyzed, Mead also studied her own, North American culture as an equal one. Her work helps us truly understand the meaning of cultural relativism: her description of the society of the USA demonstrates that she considered it neither better nor worse than that of any (Oceanian) ethnic group.

'The plot in the American movies of the middle forties comes out clearly. Boys expect their fathers to be either on their side, or else they are wicked - and may be completely defeated without guilt later in life. Girls expect their fathers, and later their husbands, to require a lot of working on; no victory is a final one, but must be re-enacted the next day. Boys see their mothers, and so ultimately their wives, as the persons from whom they get the assurance that they are good. These assurances are as necessary as the bread and jam eaten in the kitchen on a cold winter afternoon, but they are bought at a price, at the price of eschewing all the pleasure of irresponsibility, untidiness, undirected libidinal behavior - in brief, by giving up going fishing.'

80 The quotations are from Male and Female 1949. New York: William Morrow, and Sex and Temperament in Three Primitive Societies 1935: William Morrow. 


\section{CULTURAL ANTHROPOLOGY: THE EARLY YEARS}

Almost nothing connects the following anthropological trends, except for the fact that they were present at around the same time and in the same space: in the nineteenth and twentieth centuries in Europe and the USA, which was considered the 'educated' world.

At the time, culture was being researched in many different schools, some of which did not necessarily agree with each other. Below, we will briefly review some of these: German and British diffusionism, psychological anthropology originating from Freud, the contemporary impacts of British functionalism and French ethnology, neo-evolutionist ideas, and the Marxist approach.

\section{Diffusionism}

(Germany and Great Britain, 1790-1930)

The basic assumption of diffusionist approaches is that great cultural innovations (technical tools, intellectual wealth, etc.) spread from one ethnic group to the other through forms of social interaction such as migration, trade, or war. German cultural research formulated its own diffusionist theories before the British schools, and although it has declined in scientific acceptance since the 1930s, it is still popular, especially in the field of popular scientific literature. The diffusionist trend has definite merit - namely, that (as opposed to historical particularism) it highlighted the importance of the study of the links between cultures.

\section{German diffusionism}

German diffusionism dates back to the age of the Enlightenment. One of its first representatives was Johann Friedrich Blumenbach (1752-1840), who classified the Earth's cultures according to human races. ${ }^{81}$ He coined the term 'Caucasian race' - the white man is still called Caucasian in official English. Blumenbach believed that humanity had been born on the Southern slopes of the Caucasus, and he considered the Georgians living there the

\footnotetext{
${ }^{81}$ Blumenbach, Johann Friedrich (1791) 1795: De generis humani varietate nativa. Revised 3rd edition. Gottingae, Vandenhoek et Ruprecht.
} 


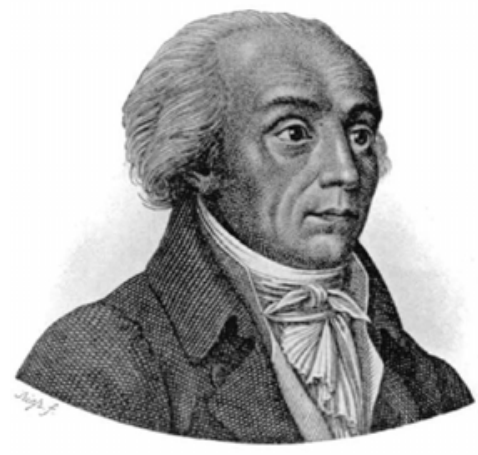

Johann Friedrich Blumenbach (1752-1840)

'most beautiful' race. His work influenced the French Joseph Arthur Comte de Gobineau (1816-1882), whose main work published in 1853-55 (Essai sur l'inégalité des races humaines) may rightly be called the precursor of racism and race theory. Blumenbach's theory also inspired the German Friedrich Max Müller (1823-1900), the first developer of the Aryan Invasion Theory.

The most influential German diffusionist school is also called the theory of cultural circles (Kulturkreise), because its basic assumption is that different cultures come from a finite number of centers. The theory of cultural circles was developed by Leo Frobenius in 1898, in relation to the study of African cultures. ${ }^{82}$ Frobenius was mostly inspired by his teacher, Friedrich Ratzel, one of the founders of anthropogeography, who significantly contributed to the birth of diffusionism by studying the spread of different tools.

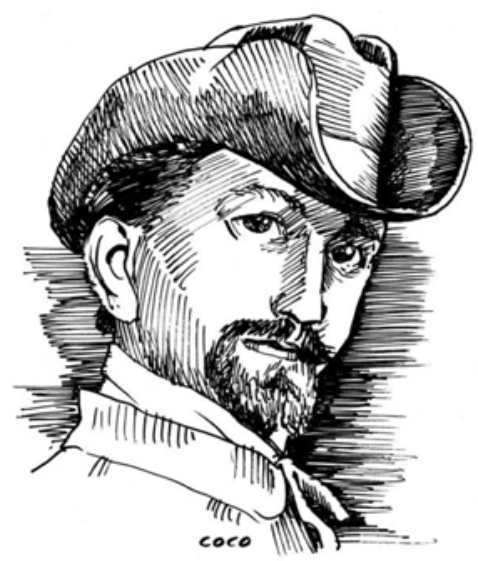

Leo Frobenius

(1873-1938)
Fritz Gräbner compared the spread of cultural traits to concentric circles, whereby individual traits mix with others to form cultural patterns and spread as they move away from the center of the circle. In his main work (Methode der Ethnologie, 1911), he emphasized that through the adequate study of sources, based on the theory of cultural circles, the history of world culture may be written. One of the key concepts of his theory is layers of culture, which means that any culture from a given period contains elements created at different times and, viewed historically, these elements may be divided into periods of creation, or layers. Gräbner believed that regions also express the layers of

82 Frobenius, Leo 1898: Der Ursprung der afrikanischen Kulturen. Berlin: Gebrüder Borntraeger. 
culture within a cultural circle, whereby more recent layers are located at the center of cultural circles, while older ones are further away or in more unfavorable regions, as far as their spread is concerned.

Wilhelm Schmidt developed his own similar theory - and published it in the journal Anthropos - at around the same time as Gräbner. Of the ideas about cultural circles promoted by these two men, Schmidt's classification became more widely known. Schmidt, who was originally a researcher of languages, partially owes his anthropological interest to his Catholic priesthood: he was preoccupied with the origin of the idea of God, and of how the monotheistic concept of God spread throughout the world. Schmidt divided the development of culture into four phases: primitive, first-, second-, and third-degree states, thereby locating cultures in an evolutionary scheme (however, diffusionism was much more sensitive to regional differences than the ideas of the evolutionists).

\section{British diffusionism}

The founder of British diffusionism, Sir Grafton Elliot Smith (1871-1937) was a pathologist, so he had a profound knowledge of anatomy. As a doctor, he worked in different areas of the British Empire, including Egypt, where his interest turned to analyzing mummies. He came to the conclusion that two types of people had lived in Egypt: small, stooped ones with weak teeth, and tall, upright ones with strong teeth. They were so different that he assumed they had been two different kinds of people. He believed that these two 'races' did not even mingle, and the tall type must have been the ruling class in ancient Egypt.

His hypothesis became so popular that he was able to launch an extended research project examining graves and bones in the Near East. His 1915 book (The Migration of Early Cultures) became a scientific bestseller during the World War, even in Germany. According to the main (minutely documented) message of the book, ancient Egypt had been populated by the smaller type of people until the sudden appearance of the taller type, which also meant the creation of a higher civilization. Smith assumed that the tall ones brought civilization with themselves, and carried it to the land of the Hittites - to Mesopotamia and India. Wherever they appeared, they created high civilization, the traces of which may still be found.

One of Smith's contemporaries and followers, William H. R. Rivers, presented this 'migration of cultures' as being of a global scale on the basis of his research of various areas of the Earth, primarily Melanesia. ${ }^{83}$

${ }^{83}$ Rivers, William Halse 1914: The History of Melanesian Society. Cambridge University Press. 
In 1915, Smith did not exactly find the starting point for the migration of cultures, but in his 1923 book (The Ancient Egyptians and the Origins of Civilization), he clearly stated that the original source of all earthly cultures was Egypt.

\section{New branches and the criticism of diffusionism}

Later anthropological and sociological schools criticized diffusionism in several respects: it diminishes the role of human ingeniousness in development, and it does not explain several aspects of culture as well as diffusionists originally believed it did.

Modern physical anthropological processes gradually challenged the theory of diffusionism after the 1930s. Later studies of the same findings proved that tall and small people all belonged to the same ethnic groups. The difference was primarily due to diet - we can still find a strong link between GDP/capita and average height.

As far as the Egyptian origin of civilization is concerned, we do not now believe that tall people arrived and invented agriculture based on irrigation, built pyramids, and put Egypt under their control, but the exact opposite: first came agriculture, then the state, which organized the watering of crops. Because of this, leaders had a better diet, which caused them to grow taller than the rest of society.

More recent theories about diffusionism are closer to science fiction than to science.

The Norwegian explorer Thor Heyerdah/ launched the Kon-Tiki expedition to 'prove' that the original natives of the Philippines came from the Andes, and sailed from Peru through the Pacific Ocean. During his Ra-II expedition in 1970, he crossed the Atlantic Ocean on an Egyptian papyrus reed boat to demonstrate the possibility of a link between the different peoples who had both built pyramids. His books were published in several languages, and his memory is preserved by the Kon-Tiki Museum in Oslo.

The Swiss writer Erich von Däniken is a representative of paleoastronautics; he believes that extraterrestrials (considered gods by cavemen) regularly visited Earth and are responsible for several fundamental cultural achievements. The Egyptian and Mexican pyramids, the Nazca lines, and the statues on Easter Island all fit into Däniken's diverse theories: how else (and for what reason) would primitive earthly men have made these?

The elaboration of diffusionist thought logically arrives at sci-fi literature: if we assume that Smith is right, and all civilizations indeed came from Egypt, the question thus arises: where did ancient Egyptians come from? 
Despite its weaknesses, diffusionist thought explained a lot in relation to the spread of technologies and other cultural traits and contributed to the fact that anthropology is still interested in the study of the links and interactions between cultures, besides the historical particularist perspective.

\section{Psychoanalytical ethnology}

(Austria-Hungary, 1910-1960)

In the nineteenth century (from the beginning of the discipline), German psychology was interested in research of both the individual (that is, the human mind) and the collective, or folk psychology. Wilhelm Wundt's tenvolume work - the first volume was published in 1900 -, Völkerpsychologie (Folk Psychology), ${ }^{84}$ may be considered one of the milestones of the topic; it set out to research folk psychology through the study of the creation of language, myth, and moral law.

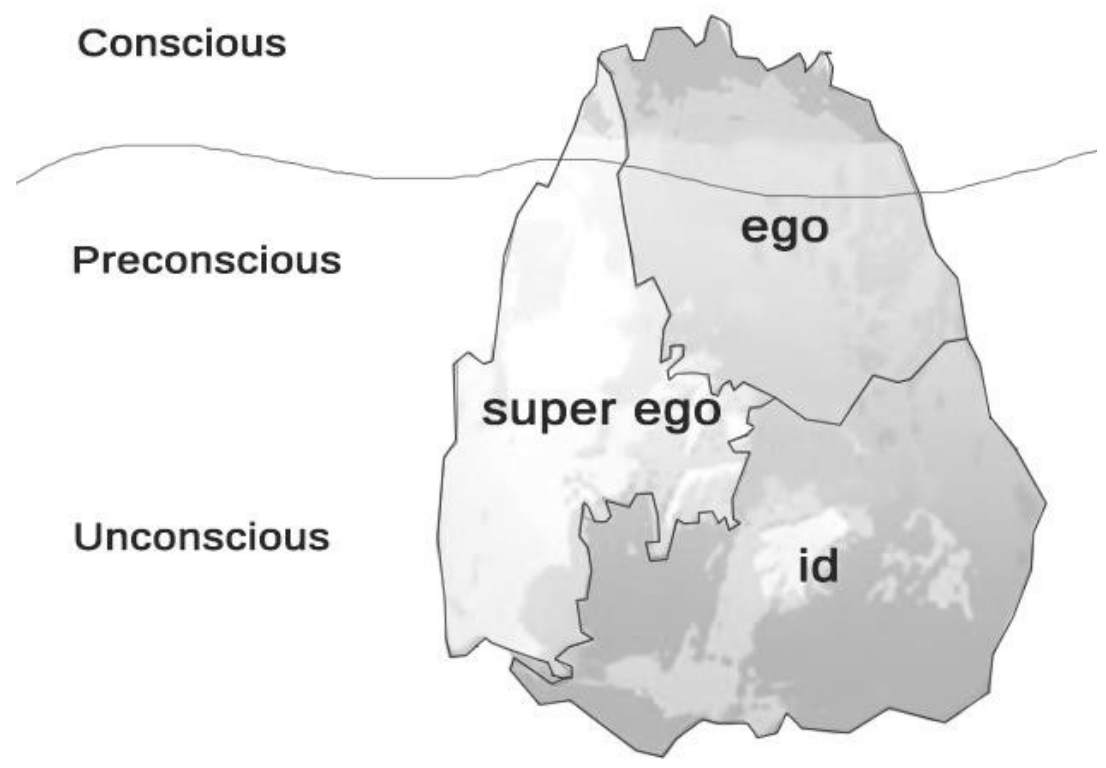

id, ego, and superego. A didactical explanation of a Freudian idea

${ }^{84}$ Wundt, Wilhelm 1900-1920: Völkerpsychologie I-X. Leipzig: Engelmann. 
Sigmund Freud's appearance - and his discovery of the subconscious and the description of the three main layers of the human soul (id, ego and superego) - changed the foundations of psychology at the beginning of the twentieth century. One of Freud's lectures, Totem and Taboo (also published in book form in 1911), approached these two concepts related to 'primitive' peoples from the perspective of psychoanalysis. According to the central message of the lecture, both concepts refer to the ancient fears of humanity. Ancient peoples know and feel these fears; this is why they use the latter concepts. 'We' Europeans, however, have lost 'our' fears connected to totem and taboo, or more precisely, have enclosed them in the collective subconscious. This means that ancient peoples have 'healthy' and 'free' natural instincts (libido), while 'we' Europeans must bear yet another civilizational burden. And what do these two concepts mean? Totem is the symbolic representation of our fear of our buried ancestors - the feeling (from childhood) that we cannot live up to the supposed expectations of our (deceased) parents and grandparents. Taboo represents fear of the unknown; of a force that is better left alone, even if we do not exactly know whether it is good or bad.

The word taboo, originally a Polynesian word, took root in English after the travel reports of James Cook, but its meaning was significantly modified by Freud. Nowadays, the term is still used in the Freudian sense, referring to something we had better not talk about, even if we are not sure of the sanction involved in breaching the taboo.

\section{Extracts from Totem and Taboo: ${ }^{85}$}

"The most widespread and strictest avoidance, which is perhaps the most interesting one for civilized races, is that which restricts the social relations between a man and his mother-in-law. In Vanna Lava (Port Patterson) a man will not even walk behind his mother-in-law along the beach until the rising tide has washed away the trace of her footsteps. But they may talk to each other at a certain distance. It is quite out of the question that he should ever pronounce the name of his mother-in-law, or she his.

It is known that also among civilized races the relation of son-in-law and motherin-law belongs to one of the most difficult sides of family organization. Although laws of avoidance no longer exist in the society of the white races of Europe and America, much quarrelling and displeasure would often be avoided if they did exist and did not have to be re-established by individuals.

The knowledge of hidden psychic feelings which psychoanalytic investigation of individuals has given us, makes it possible to add other motives to the above. Where the psycho-sexual needs of the woman are to be satisfied in marriage and family life,

${ }^{85}$ Freud, Sigmund: Totem and Taboo. London: George Routledge \& Sons, 1919. 
there is always the danger of dissatisfaction through the premature termination of the conjugal relation, and the monotony in the wife's emotional life. The ageing mother protects herself against this by living through the lives of her children, by identifying herself with them and making their emotional experiences her own. This emotional identification with the daughter may easily go so far with the mother that she also falls in love with the man her daughter loves, which leads, in extreme cases, to severe forms of neurotic ailments on account of the violent psychic resistance against this emotional predisposition.

The relation of the husband to his mother-in-law is complicated through similar feelings which, however, spring from other sources. The path of object selection has normally led him to his love object through the image of his mother and perhaps of his sister; in consequence of the incest barriers his preference for these two beloved persons of his childhood has been deflected. He now sees the mother-in-law taking the place of his own mother and of his sister's mother, and there develops a tendency to return to the primitive selection, against which everything in him resists. An added mixture of irritability and animosity in his feelings leads us to suspect that the motherin-law actually represents an incest temptation for the son-in-law."

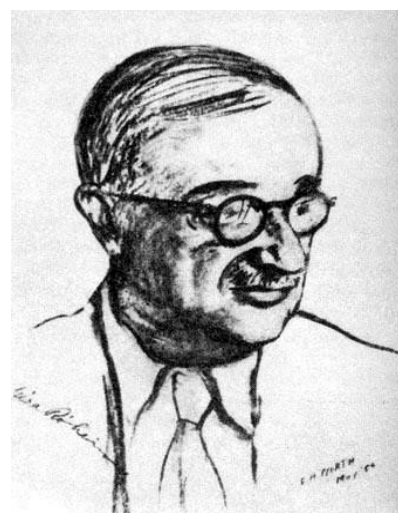

Totem and Taboo inspired a whole series of folk psychology research. Many consider Géza Róheim (a disciple of theFreudist SándorFerenczi, employed at the Museum of Ethnography) to be the founder of psychological anthropology; the French ethno-psychoanalytic scientific society was named after him. Géza Róheim was first interested in the psychoanalytical analysis of the Hungarian 'folk psyche,' primarily through the analysis of folk tales. The following extracts come from a study published in 1961 in America - the revised version of his 1925 book, Hungarian folk beliefs and customs:

"It is evident that táltos (shaman) and tudós (wise man or scientist) are the same thing. Táltos-like figures occur in Hungarian folklore even though they are not called táltos. Thus, if a seventh child can see hidden treasure through a steel mirror, or if a girl can transform herself into a black heifer or a dog, she may be called tudományos (scientific) or bübájos (enchanter). [...]

The wise man or táltos has a horse. Now the táltos horse has a prominent role in Hungarian folk tales. In one such tale, an old woman tells the hero to choose the lame horse, the worst he can find among his father's horses. When he has mounted it, the horse says, 'Close your eyes. How shall we go? Like a falcon or like thought?' [...] 
We know that a flying dream is an erection dream, that in these dreams the body represents a penis. Our hypothetical conclusion would be that the flying dream is the nucleus of shamanism. [...]

The táltos is associated with the wind or whirlwind. [In] Hódmezővásárhely they call a kind of wind the tátorjány szél (wind caused by the táltos). This is a big wind caused by the táltos fighting each other. We could compare this with the belief of some Turkish tribes in Central Asia that the wind is the breath of a gray bull. [...]

The evidence for the Asiatic origin of the Hungarian táltos is conclusive. As far as the aerial battle, bull and stallion symbolism, fertility and flying dreams are concerned, these are clearly Ural-Altaian. Curiously enough, the most striking parallels are among the Samoyed and Mongoloid (Burjat) and Eastern Turk tribes and the Lapps, and not with the Ugrian first cousins (Vogul and Ostiak). I can also say that the sexual and dream significance of these meteorological battles is fairly clear." ${ }^{\circ 6}$

In 1928, Róheim (thanks to private support) conducted research in Somalia, then in Australia, and published most of his results in English. In the thirties, he carried out field work in several countries; in 1938, he moved to the USA because of his Jewish origins and lived there until his death.

In his 1943 book (The Origin and Function of Culture), Róheim praises the healthy mindset of Australians, contrasting it with that of Europeans, who suppress all kinds of things about themselves.

"The Australian native never experiences the trauma of weaning. Babies are breastfed as long as they require it, and if their own mother does not have milk, there is always another woman to breastfeed them. That is why the oral pessimist type does not exist in Central Australia [;] there is nobody who would be constantly dissatisfied. Nobody feels that he is pushed in[to] the background, nobody is hurt all the time. All the while, these natives live in conditions we could by no means call favorable. Yet, nobody has observed a native worry for next day's food. The real situation would provide many reasons for such fears but the development of libido has not created the necessary soil. With such lenient mothers, we would all be heroes knowing no fear." ${ }_{87}$

As I mentioned earlier, the disciples of Franz Boas, just like the followers of Freud and Géza Róheim, are often called psychological anthropologists. When talking of Franz Boas and his disciples, I prefer the name cultural relativist school, while for the latter, I use the name psychoanalytical anthropology or ethnography.

\footnotetext{
${ }^{86}$ Hungarian Shamanism. In: Psychoanalysis and the Social Sciences. Ed. G. Róheim Vol. III. IUP New York, 1961. Pp. 131-169.

${ }^{87}$ Róheim Géza 1932: Die Psychoanalyse primitiver Kulturtypen. Imago journal, XVIII., pp. 297- 563.
} 
Psychoanalysis was used less frequently in ethnographic research from the 1940s, and by the 1960s this trend had become outdated. However, psychological approaches are still often used for understanding cultures, or the other way round - anthropological methods like participant observation are used in psychology. Psychological anthropology is the term used to refer to all these approaches.

\section{French Ethnology (1880-1950)}

Nineteenth-century French ethnology was based on evolutionary theory, just like Anglo-Saxon anthropology. Without going into the details of French evolutionary ethnology, we will briefly refer to a few notable personalities, such as Pierre Paul Broca, who launched anthropological education in 1875. The syllabus of École d'Anthropologie de Paris contained anatomy, biology, archeology, demography, and geography as well, while the two outstanding teachers of the École, Hovelacqué and Hervé, who - in a book they published in $1887^{88}$ - formulated one of the main principles of cultural relativism; namely, that humanity comes from one common ancestor. Another notable figure was Maurice Delafosse, who worked in Ivory Coast as a colonial officer and ethnologist and who, as a young man, had participated in the movement of 'armed brothers' against the trade of slaves.

\section{The influence of Émile Durkheim and Marcel Mauss on French ethnology}

At the turn of the century, French social scientific thinking was greatly influenced by the work of David Émile Durkheim. In his 1893 piece on the division of work in society, ${ }^{89}$ Durkheim proposed a general theory that was both evolutionary and structuralist at the same time. According to Durkheim, members of society may cooperate on the basis of two principles, which he called mechanic and organic solidarity.

\footnotetext{
88 Hovelacque, Abel; Georges Hervé 1887: Précis d'anthropologie. Paris: Delahaye et Lecrosnier.

89 Durkheim, Émile 1893: De la division du travail social, étude sur l'organisation des sociétés supérieures. Paris: Alcan.
} 



Émile Durkheim (1858-1917) and Marcel Mauss (1872-1950)

In the case of mechanic solidarity, people help their more unfortunate fellows without asking (i.e., mechanically). People help each other because this is the only behavior their culture teaches them. Émile Durkheim assumed that mechanical solidarity characterizes communities distant from our world (in time or in space): in a tribal community, for instance, if a member of the tribe is in trouble, all other members of the tribe, especially blood relatives, are obliged to help. With mechanical solidarity, the division of work is at a low level.

Modern societies are characterized by organic solidarity. If we need something, we do not primarily turn to our immediate surroundings for help but to a social institution. If we fall ill, we go to a doctor. The doctor is not paid by the patient or his close relatives but through the social security system, a social institution. Thus social security and hospitals play the same role in society as organs in the human body - hence the name organic solidarity..$^{90}$

Twenty to thirty years later, Radcliffe-Brown, a leading figure in British structuralist-functionalist anthropology, formulated similar thoughts. Instead of organic solidarity, he wrote of social structures and their functional links (based on Herbert Spencer). Durkheim's influence is obvious in British functionalism, although Radcliffe-Brown refers to two other of Durkheim's works: Règles de la Méthode Sociologique, published in 1895, and Suicide,

90 Several people formulated similar thoughts in French social sciences: e.g., René Worms, in his Société et organisme, published in 1896. 
published two years later for demonstrative reasons. ${ }^{91}$ These books are now considered seminal works in modern sociology, as it is in them where Durkheim declares that sociology must deal with the great issues of society (with social facts), for the analysis of which he suggested using statistical procedures and big samples.

Durkheim may rightly be considered one of the (re)creators of French sociology because of his role in building institutions (among other things). ${ }^{92}$ Durkheim also continued his anthropological work, which was reinforced from the 1900s onwards by his nephew, Marcel Mauss, with whom he wrote an essay entitled De quelques formes de classification in 1901-02.93 Durkheim's later works (his book on the religious life of Australian natives, and his pamphlet on German mentality during World War I) are also of an anthropological nature. ${ }^{94}$

After Durkheim's death in 1917, Marcel Mauss continued the ethnological research and published most of his results in L'Année sociologique, founded by Durkheim. Mauss wrote one single book in his life, on the trade customs of 'primitive' peoples, but published a whole series of articles. An edited version of his essays was published in the year of his death, 1950, with the title Sociologie et anthropologie. ${ }^{95}$

Although Mauss is praised by many as the 'renewer' of French ethnology, ${ }^{96}$ we must add that anthropology went through enormous changes in the Anglo-Saxon world and Marcel Mauss ignored these changes. To mention just one example: in British and American anthropology, the need for research based on field work had become self-evident - Marcel Mauss, however, never conducted field work; he remained an armchair scholar.

91 Durkheim, Émile 1895: Règles de la Méthode Sociologique. Paris, Alcan. Same author 1897: Le suicide: Étude de sociologie. Paris, Alcan.

${ }^{92}$ Contemporary scholars looked at René Worms as the institutional founder of French sociology as his work for the institutionalization of sociology as a science was much more widely accepted by society; for example, he founded the International Institute of Sociology (IIS), which is still in operation, as well as the first journal of sociology (1893).

${ }_{93}$ Durkheim, Émile; Marcell Mauss 1901-02: De quelques formes de classification. Contribution à l'étude des représentations collectives. In: L'année sociologique 6.

${ }_{94}$ Durkheim, Émile 1912: Les formes élémentaires de la vie religieuse: Le système totémique en Australie. Paris, Alcan. Same author 1915: L'Allemagne au-dessus de tout: La mentalité allemande et la guerre. Paris, Colin.

${ }_{95}$ Mauss, Marcel 1923-24: Essai sur le don. Forme et raison de l'échange dans les sociétés archaïques. In: L'année sociologique. (This also appeared in book form in 1925.) Same author 1950. Sociologie et anthropologie. Preface by Claude Lévi-Strauss. Paris: Presses universitaires de France. The annotated edition of Mauss' collected works was published in Paris by Minuit in 1868-69; the series was edited by Pierre Bourdieu, and the volumes were edited by Viktor Karády. I. - La fonction sociale du sacré. II. - Représentations collectives et diversité des civilisations. III. - Cohésion sociale et division de la sociologie.

${ }^{96}$ Mauss is treated as a 'renewer' of French ethnology by Claude Lévi-Strauss, Pierre Bordieu, and Viktor Karády in works that are referred to in the previous footnote. 


\section{Paul Rivet and linguistics in French ethnology}

French ethnology between the two World Wars was greatly influenced by the development of linguistics, which led to the creation of French structuralism (a trend to researching culture primarily through the study of the inner structures of language) in the fifties. French structuralism will be covered in the next chapter that discusses the more recent theories of anthropology; in the following section, I refer to Paul Rivet's work.

In 1901, Rivet travelled to Ecuador as a physicist to help precisely determine the line of the Equator. The beauty and the curiosities of the country compelled him to stay for six years, during which he carried out ethnographical and archeological research, and married a local woman. He later published his results from this period in two volumes. ${ }^{77}$ Later, he worked in the Musée d'Ethnographie du Trocadéro, and in 1937 became the director of the institution, refounded under the name Musée de l'Homme. When the museum was reorganized, he insisted on making it a place of research as well as a place for displays, where important linguistic research could be conducted. Under his direction, his colleagues assembled the grammars and dictionaries of, and linguistically analyzed hundreds of native languages - some of which are now extinct. Paul Rivet himself carried out important studies in Latin America, Australia, and Oceania; he concluded, for instance, that Latin America may have been populated from the direction of Polynesia not only through the Bering Strait (this assumption has since been reinforced by research).

\section{Functionalism in British anthropology (1930-1960)}

Even between the two world wars, British anthropology preserved its leading role in the research of culture. Thanks to its impressive traditions, to its excellent educational and research institutions, to the financial support derived from the needs of a colonizing empire, and to a number of acknowledged British anthropologists, British anthropology was solidly established during the thirties and forties. Nevertheless, this strong school of anthropology underwent significant transformation both methodologically and theoretically.

As far as methodology is concerned, fieldwork started to rise in popularity thanks to the pioneering work of Bronisław Kasper Malinowski, ending the era of armchair anthropologists. Anthropological theory also underwent renewal, while in the 1920s Alfred Reginald Radcliffe-Brown was a leading figure of the

${ }_{97}$ Rivet, Paul 1912, 1922: Éthnographie ancienne de l'Équateur. Paris. 
functionalist approach. According to an article of his published in $1935,{ }^{98}$ cultures consist of smaller structural units (structures) that are united functionally.

At the end of the thirties, Malinowski further elaborated the functionalist approach and formulated his own theoretical framework. ${ }^{99}$ Malinowski believed in methodological individualism, by which he meant that anthropological research should concentrate on individuals instead of structures. Most cultural achievements may be traced back to the simple fact that people regularly need food, drink, and social life.

Posterity (to distinguish between the two) often calls Malinowski's approach biopsychological functionalism, while that of Radcliffe-Brown structuralist functionalism. The debate between proponents of the two approaches may be considered the first great battle in cultural anthropology between methodological holism and methodological individualism. Methodological individualism strictly concentrates on individuals during research, while methodological holism studies groups of people. The debate still continues: both approaches have their followers and adversaries, and both research directions have led to valuable results in recent decades.

\section{Alfred Reginald Radcliffe-Brown and the structuralist- functionalist approach}

Radcliffe-Brown originally studied natural sciences at Trinity College in Cambridge, but his interest turned to anthropology when William Rivers told him of his recent experiences from the 1898 Haddon-expedition to the Torres Strait. He carried out his first field work in 1906-08 on the Andaman Islands in the Bay of Bengal. Upon his return, he read Émile Durkheim's works, which greatly impressed him; the results of his 1922 field work were written according to the functionalist perspective based on Durkheim's concepts. ${ }^{100}$

From 1931, Radcliffe-Brown taught anthropology at the University of Chicago; his lectures explaining the functionalist approach were published in 1935 in American Anthropologist.

"So far as I know the first systematic formulation of the concept [of function] as

98 Radcliffe-Brown; Alfred Reginald 1935: On the Concept of Function in Social Science. In: American Anthropologist, 37/3, Part 1 (Jul.-Sep.), pp. 394-402. His theory may more easily be understood from his 1937 series of lectures, published posthumously by his students: same author. 1957: A Natural Science of Society: based on a series of lectures at the University of Chicago in 1937.

99 Malinowski, Bronisław (1939) 1944: The Functional Theory. In: The Scientific Theory of Culture and other essays. University of North Carolina Press. (Reprint edition: 2002, Routledge.)

100 Radcliffe-Brown, Alfred Reginald 1922: The Andaman islanders; a study in social anthropology. Cambridge: University Press. Same author 1931: The social organization of Australian tribes. Melbourne: Macmillan \& Co. 


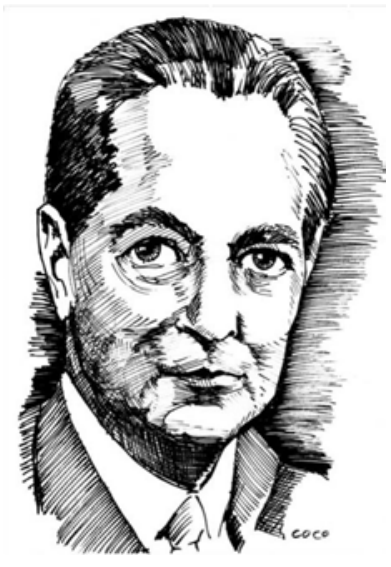

Alfred Reginald Radcliffe-Brown (1881-1955)

applying to the strictly scientific study of society was that of Émile Durkheim in 1895. The concept of function applied to human societies is based on an analogy between social life and organic life....

As the terms are here used the organism is not itself the structure; it is a collection of units (cells or molecules) arranged in a structure, i.e., in a set of relations; the organism has a structure. As long as it lives the organism preserves a certain continuity of structure... It is through and by the continuity of the functioning that the continuity of the structure is preserved.

To turn from organic life to social life, if we examine such a community as an African or Australian tribe we can recognize the existence of a social structure. Individual human beings, the essential units in this instance, are connected by a definite set of social relations into an integrated whole. The continuity of the social structure, like that of an organic structure, is not destroyed by changes in the units. The social life of the community is here defined as the functioning of the social structure. The function of any recurrent activity, such as the punishment of a crime, or a funeral ceremony, is the part it plays in the social life as a whole and therefore the contribution it makes to the maintenance of the structural continuity." 101

\section{The origin of the term social anthropology}

In the thirties, Radcliffe-Brown liked to call his own discipline 'social anthropology.' His aim was to decrease or abolish the distinction between (French or German) sociology and anthropology considered Anglo-Saxon. He hoped to find more and more researchers who (just like him) were working in both disciplines of social science at the same time.

"I conceive of social anthropology as the theoretical natural science of human society, that is, the investigation of social phenomena by methods essentially similar to those used in the physical and biological sciences. ... There are some ethnologists or anthropologists who hold that it is not possible, or at least not profitable, to apply to social phenomena the theoretical methods of natural science. For these persons

101 Radcliffe-Brown, Alfred Reginald 1935: On the Concept of Function. American Anthropologist, 37/3, pp. 394-402. 
social anthropology, as I have defined it, is something that does not and never will exist. For them, of course, my remarks will have no meaning, or at least not the meaning I intend." 102

He, however, would be disappointed in the results: the term social anthropology is now used in a narrower sense than either anthropology or sociology, designating only British anthropology.

\section{The significance of relations in cultural anthropology}

A person who follows recent news about academic research would most probably think about physics, information science, or microbiology when they hear about networks. It is easy to overlook the fact that social network analysis is over eighty years old. While sociology primarily links the acknowledgement of the importance of relations to an article from 1973 by Mark Granovetter (The Strength of Weak Ties), in cultural anthropology the study of social ties dates back even further. Radcliffe-Brown declared as early as in an article from 1935 about the functional approach that social structures cannot be studied in themselves, but only through their mutual links:

"It is rarely that we find a community that is absolutely isolated, having no outside contact. At the present moment of history, the network of social relations spreads over the whole world, without any absolute solution of continuity anywhere. This gives rise to a difficulty which I do not think that sociologists have really faced, the difficulty of defining what is meant by the term 'a society'. They do commonly talk of societies as if they were distinguishable, discrete entities, as, for example, when we are told that a society is an organism. Is the British Empire a society or a collection of societies? Is a Chinese village a society, or is it merely a fragment of the Republic of China?"103

In a speech from 1940 that defined his program, Radcliffe-Brown clearly explained the necessity of analyzing relations. ${ }^{104}$ Many experts consider this

\footnotetext{
102 Radcliffe-Brown, Alfred Reginald 1940: On Social Structure. The Journal of the Royal Anthropological Institute of Great Britain and Ireland, 70/1, pp. 1-12.

${ }_{103}$ Radcliffe-Brown, Alfred Reginald 1935: On the concepts of function and social structure in social science. In: ARS; chapter IX.

104 Radcliffe-Brown, Alfred Reginald 1940: On Social Structure. In: Journal of the Royal Anthropological Institute of Great Britain and Ireland, 70: pp. 188-204. The discourse was given as an inaugural speech when he was appointed director of the Royal British Institute of Anthropology.
} 
to be the beginning of the analysis of social networks. ${ }^{105}$ In his speech, he pointed out that most anthropologists support structuralist functionalism but they do not notice that, on the one hand, some structures are connected to each other, while on the other hand, structures are made up of individuals who are also parts of several structures at the same time. Research - he suggested - should now focus on the links between structures instead of describing structures.

"I am aware, of course, that the term 'social structure' is used in a number of different senses, some of them very vague. ... There are some anthropologists who use the term social structure to refer only to persistent social groups... But I find it more useful to include under the term social structure a good deal more than this.

In the first place, I regard as a part of the social structure all social relations of person to person. ... In an Australian tribe the whole social structure is based on a network of such relations of person to person, established through genealogical connections.

Secondly, I include under social structure the differentiation of individuals and of classes by their social role. The differential social positions [...] are just as much determinants of social relations as belonging to different clans or different nations.

In the study of social structure, the concrete reality with which we are concerned is the set of actually existing relations, at a given moment of time, which link together certain human beings." ${ }^{106}$

Several of his contemporaries considered Radcliffe-Brown's speech to be cynical. His followers felt that, having persuaded everyone of the usefulness of methodological holism, the master himself was now recommending methodological individualism, which became a source of contention.

Some scholars, however, were happy with the new research direction. The Manchester school grew out of the social anthropology department in Manchester (founded in 1947 and chaired by Max Gluckman), and its African partner, the Rhodes-Livingstone Institute, in Rhodesia (the first research institute on the continent). Their work significantly contributed to the progress made in anthropology, primarily by creating the field of social network research. For instance, Bruce Kapferer, John Barnes and J. Clyde Mitchell conducted field work in African cities and were confronted with the problem of being able to describe the observed relations as only imperfect,

105 See for instance: Scott, John (ed.) 2002: Social networks: critical concepts in sociology 1-4. London; New York: Routledge.

106 Radcliffe-Brown, Alfred Reginald 1940: On Social Structure. In: Journal of the Royal Anthropological Institute of Great Britain and Ireland, 70: pp. 188-204. 
ever-changing structures. The organization of structures gradually led to the first models of social networks. ${ }^{107}$

Polányi's former disciple, George Dalton, was an important figure in economic anthropology who also recognized the importance of social network analysis. One of his students, Larissa Adler-Lomnitz, published a brilliant article on the relations of the Chilean middle class in 1971. The article is as much a milestone in cultural anthropology as Granovetter's 1973 essay in the field of sociology.

The study of personal relations between social institutions is called interlock research in modern social network analysis. Interlock is still a fertile and flourishing research direction.

\section{Bronisław Kasper Malinowski and biopsychological functionalism}

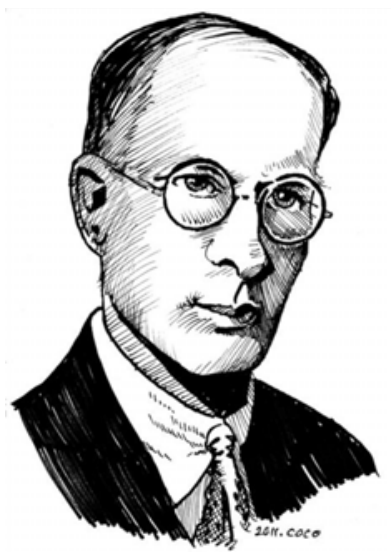

Bronisław Kasper Malinowski (1882-1942)
Bronisław Malinowski was born in Krakow, within the Polish territory of the AustroHungarian Monarchy. His father, a professor of Slavic studies at Krakow University, was also an amateur ethnographer who took early ethno photos, among other subjects. Malinowski graduated in 1908 from Krakow University (he had studied natural sciences) and his interest turned to anthropology, inspired by Frazer's The Golden Bough.

First he went to Germany, where he learned psychology with Wundt; he then conducted research at the British Museum in England and studied anthropology at the London School of Economics. He graduated in 1913 and defended his doctoral title in 1916.

He first presented his theory in 1922 in the preface of a book he wrote about the Trobrian Islands, ${ }^{108}$ then published it in rewritten forms in the 1930s. The summary volume (The Scientific Theory of Culture) was published after his death, in 1944.

\footnotetext{
107 Mitchell, J. Clyde (ed.) 1969: Social Networks in Urban Situations: Analyses of Personal Relationships in Central African Towns. Manchester: Manchester University Press, Published for the Institute for Social Research, University of Zambia.

108 Malinowski, Bronisław K. 1922: Argonauts of the Western Pacific. London: Routledge and Kegan Paul.
} 


\section{"General Axioms of Functionalism}

I would suggest that all experience in the field, as well as the scrutiny of the really important manifestations of organized human behavior, demonstrate the validity of the following axiom:

Culture is essentially an instrumental apparatus by which man is put in a position the better to cope with the concrete specific problems that face him in his environment in the course of the satisfaction of his needs.

It is a system of objects, activities, and attitudes in which every part exists as a means to an end.

It is an integral in which the various elements are interdependent.

Such activities, attitudes and objects are organized around important and vital tasks into institutions such as the family, the clan, the local community, the tribe, and the organized teams of economic cooperation, political, legal, and educational activity.

From the dynamic point of view, that is, as regards the type of activity, culture can be analyzed into a number of aspects such as education, social control, economics, systems of knowledge, belief and morality, and also modes of creative and artistic expression." 109

Malinowski summarized his theory in a table published in AJS. ${ }^{110}$ The table helps us understand why posterity calls Malinowski's approach biopsychological functionalism.

109 Malinowski, Bronisław 1939: The Functional Theory. In: Malinowski, Bronisław 1944: A Scientific Theory of Culture and Other Essays. Chapel Hill: The University of North Carolina Press, pp. 145176.

110 Malinowski, Bronisław 1939: The Group and the Individual in Functional Analysis. The American Journal of Sociology, 44/6, pp. 938-964. 


\begin{tabular}{|c|c|c|c|c|c|}
\hline A & B & C & D & E & $\mathrm{F}$ \\
\hline $\begin{array}{l}\text { Basic needs } \\
\text { (individual) }\end{array}$ & $\begin{array}{l}\text { Direct } \\
\text { responses } \\
\text { (Organized, i. } \\
\text { e., collective) }\end{array}$ & $\begin{array}{l}\text { Instrumental } \\
\text { needs }\end{array}$ & $\begin{array}{l}\text { Respons- } \\
\text { es to } \\
\text { Instrumental } \\
\text { Needs }\end{array}$ & $\begin{array}{l}\text { Symbolic } \\
\text { and } \\
\text { integrative } \\
\text { needs }\end{array}$ & $\begin{array}{l}\text { Systems of } \\
\text { thought and } \\
\text { faith }\end{array}$ \\
\hline $\begin{array}{l}\text { Nutrition } \\
\text { (metabolism) }\end{array}$ & $\begin{array}{l}\text { Commis- } \\
\text { sariat }\end{array}$ & $\begin{array}{l}\text { Renewal } \\
\text { of cultural } \\
\text { apparatus }\end{array}$ & Economics & $\begin{array}{l}\text { Transmis- } \\
\text { sion of } \\
\text { experience } \\
\text { by means } \\
\text { of precise, } \\
\text { consistent } \\
\text { principles }\end{array}$ & Knowledge \\
\hline $\begin{array}{l}\text { Repro- } \\
\text { duction }\end{array}$ & $\begin{array}{l}\text { Marriage } \\
\text { and family }\end{array}$ & & & & \\
\hline $\begin{array}{l}\text { Bodily } \\
\text { comforts }\end{array}$ & $\begin{array}{l}\text { Domicile } \\
\text { and dress }\end{array}$ & $\begin{array}{l}\text { Charters of } \\
\text { behavior } \\
\text { and their } \\
\text { sanctions }\end{array}$ & $\begin{array}{l}\text { Social } \\
\text { control }\end{array}$ & & \\
\hline Safety & $\begin{array}{l}\text { Protection } \\
\text { and defense }\end{array}$ & & & $\begin{array}{l}\text { Means of } \\
\text { intellectual, } \\
\text { emotional, } \\
\text { and prag- } \\
\text { matic control } \\
\text { of destiny } \\
\text { and chance }\end{array}$ & $\begin{array}{l}\text { Magic, } \\
\text { religion }\end{array}$ \\
\hline Relaxation & $\begin{array}{l}\text { Systems } \\
\text { of play and } \\
\text { repose }\end{array}$ & $\begin{array}{l}\text { Renewal of } \\
\text { personnel }\end{array}$ & Education & & \\
\hline Movement & $\begin{array}{l}\text { Set activities } \\
\text { and systems } \\
\text { of communi- } \\
\text { cation }\end{array}$ & & & & \\
\hline Growth & $\begin{array}{l}\text { Training and } \\
\text { apprentice- } \\
\text { ship }\end{array}$ & $\begin{array}{l}\text { Organization } \\
\text { of force and } \\
\text { compulsion }\end{array}$ & $\begin{array}{l}\text { Political } \\
\text { organization }\end{array}$ & $\begin{array}{l}\text { Communal } \\
\text { rhythm of } \\
\text { recreation, } \\
\text { exercise, and } \\
\text { rest }\end{array}$ & $\begin{array}{l}\text { Art } \\
\text { Sports } \\
\text { Games } \\
\text { Ceremonial }\end{array}$ \\
\hline
\end{tabular}

Synoptic survey of biological and derived needs and their satisfaction in culture 
The debate between structural and biopsychological functionalism may be considered the first great battle in cultural anthropology between methodological holism and methodological individualism. The issue is still unresolved: when trying to understand a certain culture, there is and probably will continue to be research that strictly concentrates on individuals, as well as research that focuses on groups of people.

The debate ended with Malinowski's death in 1942. Left without an opponent, Radcliffe-Brown's assumptions appeared to be accepted for a while, but Malinowski's 'spirit' returned in posthumous publications and the writings of his followers. Nowadays, we tend to think that both holist and individualist approaches deserve a place in anthropological research.

\section{Neo-evolutionist approaches (1930-1970)}

Anthropology of the 1930s basically challenged the evolutionist perspective, rejecting the principle of linear development, the comparative method, and the parallels between cavemen and 'primitive' cultures. To mention just a few examples:

- From the 1910s, the idea of historical particularism or cultural relativism, linked to Franz Boas of Columbia University, strongly rejected comparative ethnography and promoted the separate analysis of different cultures;

- In the 1920s, the British Radcliffe-Brown declared the 'historical method' (when a cultural achievement of a primitive people is placed on our historical scale) unscientific, and proposed as an alternative procedure the analysis of social structures (based on Durkheim);

- In the 1930s, several evolutionist hypotheses were disproved on the basis of the Yale database Human Relations Area Files. For instance, the latter found no evidence for Morgan's hypothesis that ancient societies were divided into big families and the widely held idea that cavemen lived in a matriarchal society.

The concept of development, however, did not immediately disappear from anthropological thinking: from time to time, it resurfaced and was only pushed into a marginal position in cultural research in the 1970s.

In the 1940s and '50s, Julian H. Steward became dean of the department of anthropology at Columbia University (the most prestigious position at the time, and for a long time afterwards, in American cultural anthropology). Steward, as opposed to the founder, Franz Boas, did not fight against evolutionary theory, although he preferred the idea of multilinear development to a unilinear one. To put it more simply, Steward accepted that each culture may only 


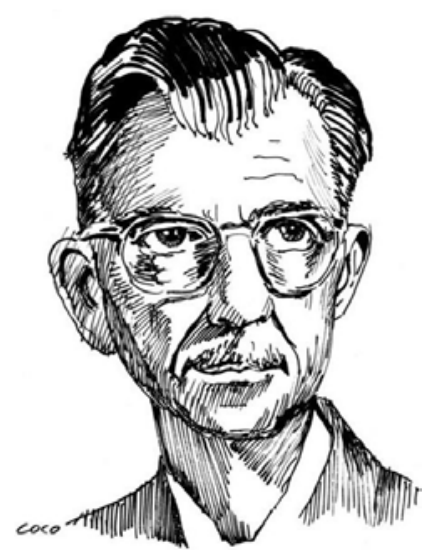

Julian H. Steward (1902-1972)

be interpreted in its own geographical and historical context, but within that, however - said Steward -, development may indeed be interpreted. His theory later became known as specific evolution theory (based on Marshall Sahlins"11); he preferred to use the term cultural ecology, which referred to the degree by which a given culture is capable of adapting to its environment. ${ }^{112}$ Steward demonstrated the usefulness of this specific theory of evolution in a presentation about South American cultures in 1959.

The book abstained from including comparative studies and from 'calling into account' European civilizational traits, but in some well-defined geographical regions, such as the Chancay valley, the authors did employ the concept of development. ${ }^{113}$

Leslie Alvin White (one of Steward's colleagues) also listened to lectures by Franz Boas at Columbia in the 1920s, but explicitly challenged the teachings of historical particularism in the 1940s.

"The anti-evolutionists, led in America by Franz Boas, have rejected the theory of evolution in cultural anthropology - and have given us instead a philosophy of "planless hodge-podge-ism." 114

According to White, the 'only' problem with the theory of evolution of Morgan, Spencer, and others was that they had used the wrong measures. The use of materials, monotheism, or agricultural techniques - these are indeed categories that vary from one historical and geographical environment to the other. There is, however, a characteristic that may always be a good measure of the achievement of human culture, thus making the level of development of different cultures comparable (regardless of whether we think in terms of

\footnotetext{
111 In his book published in 1960, Marshall Sahlins divided modern theories of evolution into two big groups: the theory of Steward (and his colleagues) are called specific, while that of Leslie White and his followers was called general theory of evolution. Source: Sahlins, Marshall D.: Evolution: Specific and General. In: Sahlins, Marshall D.; Elman R. Service (ed.) 1960: Evolution and Culture. University of Michigan Press.

112 Steward, Julian H. 1955: Theory of Culture Change: The Methodology of Multilinear Evolution. University of Illinois Press.

${ }^{113}$ Steward, Julian H.; Louis C. Faron 1959: Native Peoples of South America. New York: McGraw-Hill.

114 White, Leslie A. 1943: Energy and the Evolution of Culture. In: American Anthropologist, pp. 45, 335.
} 


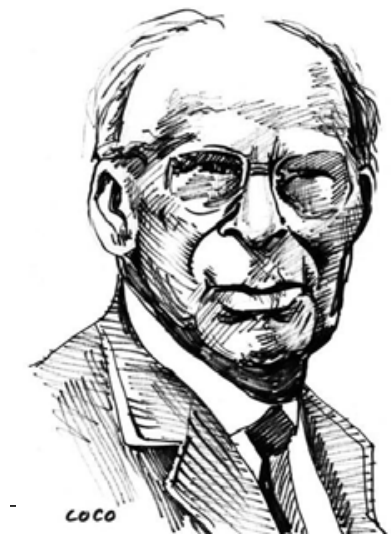

Leslie A. White

(1900-1975 uni- or multilinear evolution). This 'universal' measure - according to White - is none other than energy consumption per capita.

White says that, in ancient societies, people only had their own bodies (each capable of producing about 0.05 horsepower), and energy use increased first through the use of beasts of burden, then through increasingly complicated machines. He completed his theory with a focus on energy efficiency:

"We have, in the above generalizations the law of cultural evolution: culture develops when the amount of energy harnessed by man per capita per year is increased; or as the efficiency of the technological means of putting this energy to work is increased; or, as both factors are simultaneously increased." 115

White's theory is known by posterity as the 'general theory of evolution' (once again based on Sahlins); he preferred to call it the extension of the second law of thermodynamics. ${ }^{116}$

According to his formula, $\mathrm{P}=\mathrm{E} \times \mathrm{T}$, where $\mathrm{E}$ is yearly energy consumption per capita, $T$ is the efficiency of energy use, and $P$ is the level of cultural development as measured by the goods that are produced.

In the 1950s and '60s, White exerted great influence on cultural materialist and economic anthropological schools. In the 1970s, his theory of evolution was challenged by many because this was the decade when the optimistic belief that development helps solve social problems gradually disappeared from public life. The atmosphere changed for several reasons - among others:

- the 1968 student revolts and the Soviet occupation of Prague, which dissolved confidence in the existing regimes;

- the strengthening of the idea of environmental sustainability, especially after the report of the 1972 Club of Rome meeting;

- the first oil crisis in 1973, which added a negative prefix to the universal measure of energy consumption per capita among consumers sensitive to petrol prices.

\footnotetext{
115 White, Leslie A. 1943: Ibid, p. 338.

116 White, Leslie A. 1959: The Evolution of Culture: The Development of Civilization to the Fall of Rome. New York: McGraw-Hill, Chapter 2.
} 
In the twenty-first century, we do not need to explain why energy consumption per capita is not a good measure of 'development.' The energy crisis of our age has proved permanent and, in my view, the less energy a person, a household, a city, or a country consumes, and the smaller their ecological footprint, the more they may be considered developed.

The word 'development' is nevertheless still used. Thanks to widely known schools of economics, the public believes that sustained welfare is based on (sustainable) economic growth. On a macro level, the most important measurement of this is GDP/capita; citizens, just like economic analysts and international financial organizations, all expect this to grow every year. The different financial programs of the European Union, which are mostly integrated with national development plans, also support development. In this development-orientated atmosphere, it is difficult to hear the quiet voice of cultural anthropology that has rejected the illusion of development in its own field, the study of culture, and puts emphasis instead on adaptation to the environment and long term sustainability.

\section{Marxist anthropology and cultural materialism (1910-1990)}

Karl Heinrich Marx created a linear theory of evolution in the nineteenth century, according to which human societies have moved along a unique path since hunter-gatherers, which led to - among other things - Asian means of production and Feudalism, to capitalism and finally communism.

Marx formulated his position in opposition to the system of ideas of German philosophers of the previous one or two generations - primarily to those of Kant's and Hegel's. The latter believed, following Plato, that the foundations of human culture must be formulated in the human intellect; in the world of thoughts (ideas). Marx called these philosophers idealists and compared this to his own materialism. According to the materialist understanding of history, social, political, legal, etc. relations cannot be understood in themselves because they are all based on the material conditions of life. Needs are satisfied by production; social and cultural phenomena are built on this economic basis.

In Marx's theory of development, changes in the means of production and the conditions of production linked to them (the totality of economic relations) are a linear process. Marx had a deterministic perspective: the coexistence of certain economic factors forces social change. For instance, the supposed dissolution of hunter-gatherer communities was forced by the 
discovery of agriculture/animal farming, and then the discovery of more and more technical and economic achievements and their accumulation led to the creation of increasingly developed social systems. As society developed, the level of exploitation first increased, then decreased. Marx assumed that the final stage of social evolution would be a society without any exploitation called 'communism.'The leaving behind of each developmental level is always a revolutionary phenomenon, brought about as a result of the conflict between the exploiters and the exploited. This is why Marxism is often called a conflict theory, while other anthropological theories are called theories of harmony.

Marx's materialist theory of evolution was significantly different from other systems of ideas from the nineteenth century. Although the different Marxist approaches later re-established and further elaborated Marx's thoughts, there are a few common points still shared by all Marxist approaches (otherwise, they cannot be considered Marxist). These common points are:

- a faith in development and the accompanying evolutionist perspective;

- materialism, due to which Marxist anthropologists primarily studied the functioning of the economy (i.e. the basis) - the study of all other cultural phenomena (e. g. rites, kinship systems, etc.) deriving from this;

- Marxist dialectics, according to which in the relationship between the material world and the world of ideas, the human mind and the intellectual life of societies reflect on the surrounding physical world.

The ideas of Marxism touched all branches of the social sciences, the research of culture being no exception. In this book, for the sake of simplicity, I classify the many Marxist approaches on a regional basis: Marxism in Eastern and Western Europe, and Marxism in the USA.

The grouping is justified by the division of these areas between the two World Wars and during the Cold War. In the Soviet Union (and later in the communist countries), the Marxist approach was the only acceptable scientific trend; in Western Europe, there were many left-wing, Marxist intellectuals among the researchers of culture; in the USA, however, Marxism was persecuted, so Marxist anthropology could only be promoted using pseudonyms (for instance cultural materialism) and without direct references to Marx.

\section{Marxist social sciences and the research of culture in Eastern Europe}

The scientific life of Eastern European countries was strongly influenced by centralized, state-controlled politics of culture. Marxism was the only officially accepted direction, so in several Eastern European countries there was one 
single line of education and research in social sciences: that of MarxismLeninism. Sociology and cultural anthropology were both considered bourgeois pseudosciences and therefore banned in the Soviet Union and many socialist countries.

Ethnography was nevertheless allowed in the Soviet Union. Although it was under strict political control, interestingly enough, there were examples of the merging of Boas' tradition with Marxism in the 1930s. In 1930, a Russian disciple of Boas', Julija Averkijeva, ${ }^{117}$ conducted field work in Canada, mostly among the Tlingit; she later became a renowned professor at Moscow University.

After Stalin's death (1953), the central control of scientific thought fluctuated in the countries of the Eastern Bloc. Those in power sometimes expected a wordfor-word demonstration of Marxist thoughts in ethnographic research, while sometimes they allowed research along modern paradigms and were content with a so-called red tail, a Marxist reference at the end of the essay. Political control did not favor the birth of new thoughts and productive open scholarly debates, and thus the creation of new paradigms. If, however, the research or the researcher could slip through the complicated filter of state-socialist dictatorship, the state ensured the necessary political and economic support.

Cultural research in socialist countries was often of an applied nature. The countries of the socialist block were strongly against colonization and neo-colonialism, but in the third world spread Marxist ideas (and political attachment to the socialist block) with tools similar to those of neo-colonialism. So-called institutes of regional studies were created in Moscow: institutes for Latin America, Africa, and the Orient. Despite strict political expectations and small budgets, most of the research was not propaganda but fine scientific work. In the framework of the socialist division of work, Hungary was charged with Latin American historical research.

\section{Marxist economic anthropology}

Because of Marx's theory of materialism, Marxist researchers of culture focused on the functioning of the economy as the basis for the superstructures of social and cultural phenomena. Their work was often called political economics (based on Marx). Their writings gained relevance through the dissolution of colonial empires in the 1950s and '60s and the revolts accompanying this process in third world countries. These peasant protests

117 Averkijeva, Julija Pavlovna 1981. North American Indian Studies. Göttingen: Edition Herodot. 
kept rural societies at the center of economic anthropologists' interest for a long time. ${ }^{118}$

In Western Europe (especially in France and Southern Europe), left-wing thinking remained strong in scientific and intellectual circles after World War II. In the 1960s and '70s, a group of French Marxist anthropologists studied the effects of colonization and neo-colonialism. ${ }^{119}$ In their view, the capitalist means of production subordinates non-capitalist ways, and this hierarchy influences non-capitalist societies. According to one of the later researchers of the topic, Susana Narotzky, ${ }^{120}$ the main question for Marxist anthropology concerned the autonomy of the economy: whether production methods are organized by themselves in their own way, or are linked by a mutually effective relationship to social reproduction.

Maurice Godelier was one of the leading figures in French economic anthropology. He studied philosophy and economics, and examined the economic literature of socialist countries in depth. He was also influenced by the writings of Béla Csikós-Nagy, amongst others. His long periods of field work in Mali in 1964 made him completely disillusioned with bourgeois economics. He started to work in the field of ethnology - or more precisely, of economic anthropology, in the Laboratoire d'Anthropologie Social led by Lévi-Strauss. The extracts below are from a book of his from 1965 ${ }^{121}$; this is where he described the task of (Marxist) economic anthropology, which, in his view, should be concerned with the understanding of economic-social systems.

"If a system has inner contradictions, it does not mean that it must necessarily fail. Some contradictions within the system are constructive and even ensure dynamism within a certain time. In the ancien régime, for instance, serfs and landowners were opposed to each other but also displayed some solidarity, and their opposition - just like the one between the owner and his slaves - did not exclude their unity. [...] The difference between the contradictions of primitive community and those of class society is that

118 For instance, Service, Elman R 1966: Hunters. Prentice Hall. Marshall D. Sahlins 1968: Tribesman. Englewood Cliffs, N. J: Prentice Hall. Eric R. Wolf 1966: Peasants. Prentice Hall. Sahlins, Marshall 1972: Stone Age Economics. Chicago: Aldine-Atherton. Shanin, Teodor 1971: Peasants and peasant societies. Harmondsworth: Penguin. Popkin, Samuel L. 1979: The Rational Peasant: The Political Economy of Rural Society in Vietnam. Berkeley: University of California Press.

119 For instance Meillassoux, Claude 1964: Anthropologie économique des Gouro de Côte-d'lvoire. De l'économie de subsistance ‘a l'agriculture commerciale. Paris: Mouton. Terray, Emmanuel 1969: Le Marxisme devant les sociétés „primitives”: deux études. Paris: Maspero. Rey, Pierre Philippe 1971: Colonialisme et néo-colonialisme et transition au capitalisme. Exemple de la Comilog au Congo-Brazzaville. Paris: Maspero.

120 Narotzky, Susana 1997: New Directions in Economic Anthropology. London: Pluto Press.

121 Godelier, Maurice 1965: Object et méthodes de l'anthropologie économique. In: L'homme, 1965/2. Pp. 32-91. 


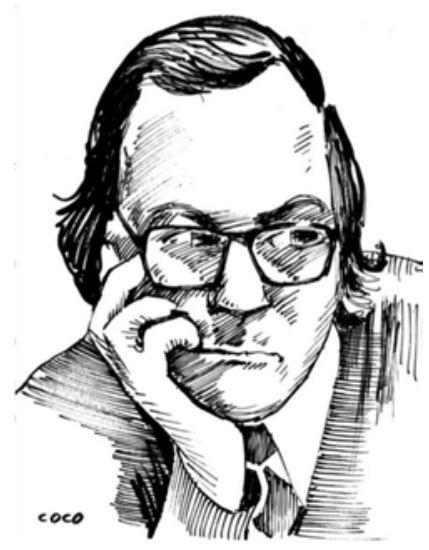

Maurice Godelier (1934-) in the case of the former, contradictions do not directly induce economic and social changes... In a society based on agriculture that burns forests to have land the contradiction is dissolved by excluding the extreme growth of the population; the destruction of the link between slave owner and slave, land owner and serf is in reality the "transformation", the destruction of the system. [...] A system reaches its optimum when the compliance of the social structures forming the system is at its maximum. Functional compliance and non-compliance leads us to the cybernetic and operational research of economic systems, to the "real" - rather than formal - logic of the development of systems. This is the theoretical task of economic anthropology."

Godelier later worked in the scientific background institute of the French communist party. A book of his from 1973 was the most important Marxist criticism of contemporary cultural anthropology. ${ }^{122}$

The Marxist trend was not the only one in economic anthropology. The term economic anthropology was first used by one of Boas' disciples, Melville J. Herskovits, in a book of his from 1952 (of the latter name ${ }^{123}$ ). Herskovits was not a Marxist, and did not even remark upon the Marxists. In the fifties, Károly Polányi's appearance created a strong non-Marxist trend. Economic life is still regularly researched by anthropologists who rarely approach their subject from a Marxist basis. ${ }^{24}$

\section{Cultural materialism}

While one had to be a Marxist in Eastern Europe, and being one was accepted in Western Europe, in the USA, it was impossible in the fifties due to the atmosphere of the Cold War. Marx's name became taboo in scientific circles

122 Godelier, Maurice 1973: Horizon, trajetc marxistes en anthropologie. Paris: Maspero.

${ }^{123}$ Herskovits, Melville J. 1952: Economic anthropology; a study in comparative economics. New York: Knopf.

124 See for instance Molina, José Luis; Hugo Valenzuela 2007: Invitación a la antropologia económica. Barcelona: Bellaterra. 
in the 1950s and '60s, and if an anthropologist had called themselves a Marxist, it would have meant the end of their career.

During the Vietnam War, and in 1968, a strong anti-imperialist rhetoric emerged in the USA and was felt in the research of culture. One of the strongest criticisms was formulated by Kathlen Gough (1968), whose articles declared that anthropology was the child of imperialism, which idea quickly became popular at the time. ${ }^{125}$

Two important elements of her criticism may be highlighted:

- anthropology has not explored its own society (more precisely: it owes us an in-depth study of Western imperialism as an international system);

- anthropologists tend to study local communities in and of themselves and thus - often unintentionally - hide the (adverse) effects that the outside world (and imperialism) have on local communities.

Marxist criticism significantly contributed to the twentieth-century 'homecoming' of cultural anthropology - the discipline started to study its own culture.

The expression cultural materialism was coined by Marvin Harris in 1968, in his influential history of ideas of anthropology: The Rise of Anthropological

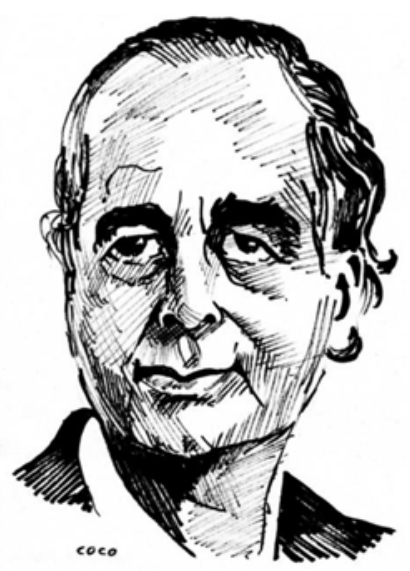

Marvin Harris

(1927-2001)
Theory. ${ }^{126}$ According to cultural materialism, the most important trait of the sociocultural system of different peoples is the way they overcome their environment and develop tools and techniques for exploiting nature. Marvin Harris says that cultural materialism '...is based on the simple premise that human social life is a response to the practical problems of earthly existence.' ${ }^{127}$

Cultural materialists primarily differ from Marxist scholars in the fact that they believe that, besides the material world, demographic characteristics serve as explanations: the culture of an ethnic group is not only explained by its resources but also by its demographic

125 Gough, Kathlen 1968: Anthropology, Child of Imperialism. In: Monthly Review, 19:11, pp. 12-27. www.monthlyreview.org

126 Harris, Marvin 1968: The Rise of Anthropological Theory. New York: Thomas Y. Crowell Company.

127 Harris, Marvin 1979: Cultural Materialism: The Struggle for a Science of Culture. New York: Random House. 
traits and those of neighboring ethnic groups - such as population density or fertility.

The appearance of a neighboring people or an increase in a group's population change the availability of natural resources. According to cultural materialists, physical factors determine cultural transformation, which may be best measured by the observation of behavior.

Marxist determinism is also demonstrated in The Rise of Anthropological Theory, which is an overview of anthropological theories. Harris shows the linear development in the history of the discipline, and the end point is cultural materialism, as represented by the author.

\section{Marxist anthropology pushed to the background}

The Marxist approach (as opposed to the other trends described in this chapter) has not come to an end: Marxism-oriented anthropology still exists. We may nevertheless observe that the Marxist trends of anthropology were slowly pushed to the background in the 1980s. The fall of the iron curtain and the Berlin Wall in 1990 pulled the ideological rug from under orthodox Marxist approaches. As the control of political power over Marxism ceased, later research of a Marxist orientation used Marx and Marxist literature rather liberally and by way of inspiration, not as a starting point.

The Marxist approach was criticized in its own time and has been criticized ever since in cultural anthropology. Below, I highlight some elements of this criticism:

\section{Marxist fieldwork}

The practice of anthropological fieldwork, formed around 1920-30, requires that the researcher rid themselves of prejudices, even of preliminary hypotheses. Maintaining the Marxist paradigm conflicted with this widespread image of fieldwork, yet Marxist anthropologists did not reinterpret fieldwork methodology.

\section{Dogmatic or orthodox Marxism}

Eastern European researchers faced difficulties stemming from rigid political regimes. The need to conform to political expectations and produce results conforming to Marx's original teachings resulted in researchers omitting fieldwork or not taking primary data into account.

\section{Evolutionist perspective}

The evolutionist perspective largely became outdated in the research of culture from the 1950s onwards. Marxist anthropologists, however, had to 
stick to it, as disavowing it would have meant rejecting their fundamental Marxist assumptions.

\section{Materialists and idealists}

Marxists (for instance, Harris and Godelier) tended to condemn all nonmaterialist approaches as idealist on the basis of Marx. The content of the term 'idealist' somewhat differed from the original Marxist interpretation: they used it to mean that other researchers - as opposed to themselves, the Marxist researchers standing on the firm ground of reality - were daydreaming and doing speculative work. With the use of the term idealist, Marxists treated many otherwise different approaches as one; this strongly contributed to the Marxists isolating themselves in the scholarly world.

\section{Conflict theory}

Another label stuck to Marxist approaches: conflict theory. According to those who believe in harmony theories (in sharp contrast with conflict theory), history is characterized by cooperation between social groups, and conflicts are rare. Transformations and adaptations are mostly long-term, peaceful processes; that is, it is not class conflict that makes the world progress. 


\section{ANTHROPOLOGY: THE MATURE YEARS}

\section{- STRUCTURALISM, COGNITIVE, SYMBOLIC, INTERPRETIVE ANTHROPOLOGY AND THE POSTMODERN TRENDS}

\section{Introduction}

After World War II, contradictory processes were launched in cultural anthropology.

On one hand, there was a process of harmonization: due to international conferences, prestigious journals, and similar training, agreement started to form about important issues, such as the subject of cultural research, the meaning of anthropological methodology, etc. The geographical division associated with cultural research became less significant than before, meaning that the difference between British social anthropology, French ethnology, Central European folklore research, and US cultural anthropology was reduced. Cultural research that developed in Latin America (and other third world countries) mostly took over the traditions of American and European anthropology - this further promoted the process of harmonization. Simultaneously, certain trends in cultural research (such as diffusionism) became less significant or disappeared completely. Due to the development of the institutional-organizational background and to the harmonization and increasingly international nature of the foundations of the discipline, the post-World-War-II era is considered by many to be the "coming of age" of cultural anthropology.

However, in a counter-process of harmonization, friction appeared in anthropology: between the 1960s and today, several trends and specialized areas of anthropology emerged - for example, political, medical, legal, historical anthropology, etc.

The emergence of different approaches was mostly justified by the interdisciplinary nature of research: researchers from other disciplines often incorporated the results of their own fields (psychology, linguistics, etc.) into anthropology, or researchers of culture started to investigate issues that had not previously been considered anthropological topics (contemporary legal or political issues, health and medicine, and physical and chemical research).

This chapter seeks to present the main observations of structuralist, cognitive, symbolic, interpretive, and postmodern anthropology, focusing on 
the significance of the most important theoretical considerations, especially that of language, from the 1950s through to the 1980s. Several approaches are only mentioned or completely ignored in the present chapter. Since such a short introduction is unavoidably incomplete, we recommend to the interested reader several books for further reading. Our overview of the history of theory ends around the mid-1980s.

\section{Text: Its Meaning, Translation, and the Interpreter}

In the present chapter, I will introduce a few schools that have strongly influenced anthropology. The aim of the following paragraphs is to highlight the links between different schools and approaches, and to present them as one continuous process in the history of ideas.

Among the schools I discuss, the structuralism of French origins (regardless of the previous results of anthropological research that focused on language) stated that human activities and observable behavior are determined by our thought structures; this means that all material findings or observable forms of behavior are not culture itself, but simply an impression of culture. The structures of thought - as demonstrated after Saussure by the founding father of structuralism, Claude Lévi-Strauss - may be discovered through the study of language.

In the 1960s, the English translation of the works of Lévi-Strauss and the emergence of generative linguistics associated with Noam Chomsky brought about a new desire for cultural research with a focus on language. The representatives of this trend are often called cognitive anthropologists, referring to the fact that they can only imagine culture through the observation of cognitive (conscious) behavior. Cognitivists all agree that language is the most important human sign system, so cognitivists must concentrate on the study of language. The claim is that if we cannot talk about something, we cannot think about it either, so it does not exist - or the other way round: all cultural phenomena first existed on the level of thought, thus there must be a word, or more precisely, a linguistic structure, for the latter.

The critics of the cognitive approach, such as Victor Turner and Mary Douglas, emphasized that humanity has developed other symbols apart from language - symbols that cannot be put into words, but which are equally valid, so it is more precise to talk about symbolic anthropology. Influenced by contemporary psychology, they also stressed that language should not be examined in its static form, because language and behavior are constructed in each moment as a response to the challenges of the environment; instead, the important thing is the investigation of interactions - 
of the way linguistic and other symbols are formed, arranged, and structured into behavior, dynamically forming interactions - this approach is called symbolic interactionism. The common merit of the cognitivists, symbolists, and adherents of other trends not mentioned here, is that together they led to a new conception of culture; one which - as opposed to previous attempts at definition - is rather widely accepted these days. Clifford Geertz summarized the new conception of culture with these words: "man is an animal suspended in webs of significance he himself has spun." 128

Interpretive anthropology started its triumphant history in 1973, with the publication of Thick Description by Clifford Geertz. The focal point of the latter is that during the interpretation of our field experience (in practice, this means the writing of our essays, or the production of our films or photo series), we must make an effort to leave the original meaning unchanged The anthropologist is a good mediator between two cultures if they publish the original expressions with their original context - Geertz gives further examples in a short text on cock fighting in Bali. The anthropologist aims at giving a precise interpretation of the meanings that exist in other cultures.

A proposed interpretation: in our day-to-day lives, we often see on our trips abroad how much things depend on the person and intention of the interpreter. One of the important traits of postmodern anthropology is facing up to the personal role of the researcher - in other words, practicing selfreflexivity. ${ }^{129}$ Culture demonstrates itself to the researcher in interactions the researcher is also part of; we have no way of knowing what culture would have been like if the researcher had not been there, while the researcher must always take their own role and influence on the field into account. It often happens that two researchers make different observations about the same field; this may be because the given culture has revealed different aspects to them, but it may also be because the different researchers have paid attention to and are sensitive to different things: their personality and state of mind leaves a trace on their field work. According to postmodern anthropology, recognizing the subtle frontier between the thoughts of the researcher and the field is a difficult but unavoidable task. The principle of self-reflexivity demands the consistent description of our own thoughts and feelings. At the end of this chapter, an extract from Renato Rosaldo's study provides an insight into this method.

128 Geertz, Clifford 1973: Thick Description: Toward an Interpretive Theory of Culture. In: The Interpretation of Cultures: Selected Essays, New York, Basic Books, 5.

129 Postmodern anthropology may much rather be considered a set of concepts and intentions than a trend. The feature I selected, self-reflexivity, is indeed important, but neither this nor any other characteristic can precisely define the meaning of postmodern. 


\section{Researching Language and Culture}

\section{Anthropology and Linguistics before Structuralism}

According to Goethe, "a man who knows four languages is worth four men": each new language opens up new worlds, and enables us to meet new people. The integration of the results of linguistics and cultural anthropology has been occurring since the beginning of cultural research, and even precedes it. Below, I present the interaction of linguistics and cultural research from the perspective of Claude Lévi-Strauss; however, first let me turn back for a moment to his immediate precursors.

The linguistic discoveries of the nineteenth century, primarily the decoding of the dead languages of the Near East, strongly promoted comparative cultural research, thus the anthropologists of the second half of the twentieth century paid attention to the systematic collection of the grammar and vocabulary of remote peoples. At the beginning of the twentieth century, linguistic collection included "small" languages spoken in hidden corners of the world, so volumes and databases describing and summarizing these languages were published one after the other. ${ }^{130}$

Upon receiving his linguistics degree, and encouraged by Franz Boas, the linguist Edward Sapir started to research the grammar of Californian people, especially that of the yanas. In The Status of Linguistics as a Science, published in 1929, ${ }^{131}$ he observes that (as opposed to the perspective of previous research - for instance, that of Malinowski's 1922 work) the significance of language research is not simply that speech allows us to relate to those who are being researched, but the fact that language provides a certain impression of the culture that is being explored. Sapir emphasized that all languages are equal because they are all able to form and mediate complex, abstract meanings, separated from reality. He and his student Benjamin Lee Whorf formulated the so-called Sapir-Whorf hypothesis, which says that each language determines its own particular way of perceiving and understanding reality. ${ }^{132}$

130 The monumental work, Les langues du monde (Languages of the World) was published in Paris in 1924, edited by Antoine Meillet and Marcel Cohen. The enlarged edition was published in 1952 with significant contributions by Paul Rivet; it is available free from several sources, e.g. http://www.jstor. org/pss/3316267. A similar volume was published in Germany in 1926: W. Schmidt: Die Sprachfamilien und Sprachenkreise der Erde. Heidelberg. In the United States, A. L. Kroeber's textbook (Anthropology), published in 1923, devotes a long chapter to linguistics.

131 Sapir, Edward 1929: The Status of Linguistics as a Science. In: Language, vol. 5. no. 4., 207- 214.

132 Both Sapir and Whorf published several pieces on the subject but there is no specific article in which they formulated a hypothesis together; the name was made up in posterity. Sapir promoted the consistent use of linguistic concepts, while Whorf wanted to introduce the concept of linguistic relativity - the expression did not take hold. (See: Whorf, Benjamin L. 1940: Science and Linguistics. In: Technology Review, 42/6.) 


\section{Ferdinand de Saussure's Influence}

The Swiss linguist Ferdinand de Saussure died in 1913; his thoughts on general linguistics were published by his disciples only after his death (as the brilliant lecturer never wrote anything down). ${ }^{133}$ According to Saussure, language is a system of signs. He insisted that linguistics studies language (langue) as an abstract system, not as speech (parole - the individual realization of language in the brain of a given speaker) or langage (this includes the whole speech process - the way speech is realized in practice). To take Saussure's example: language is like a piece of music the way it was written down by the composer; speech is the conductor's idea of the piece; langage is the performance - the music put into practice.

Saussure distinguished the diachronic (historical) and synchronic (present time) perspective, as well as outer and inner linguistics. By outer linguistics, he meant research directions on the frontier of linguistics and any other social science; for instance, historical research on the formation and expansion of languages or dialectology, which only involves the "outer" form of language without its core (the structure). For Saussure, inner linguistics is concerned with the essential, structural elements of language.

Among the numerous analogies he used in his lectures (like the parallel with music), chess is the one that best illustrates the difference between outer and inner linguistics: if chess is a language, then the material of the board, the color of the pieces, or the fact that the game comes from India, are outer facts. It is, however, an inner fact that the board is made of $8 \times 8$ squares, that both players have 16 pieces, and the rules themselves are also part of these inner facts. These inner rules characterize the structure of chess - this is why the trend launched by Saussure is called structuralism.

\section{Claude Lévi-Strauss' structuralism}

Claude Lévi-Strauss had a degree in humanities and ethnology. When he returned to France after field work in Brazil after World War II, he became increasingly interested in the correlation between language and culture. LéviStrauss was not influenced by contemporary Anglo-Saxon anthropologists, but by Saussure and structuralist linguistics, as well as Marcel Mauss' theory of exchange. In his doctoral thesis - defended in 1948 - entitled The Elementary Structures of Kinship ${ }^{134}$ he argued with Lévi-Bruhl that the main

\footnotetext{
133 Saussure, Ferdinand de 1913: Cours de linguistique générale. éd. Payot.

134 Lévi-Strauss, Claude 1949: Les structures élémentaires de la parentée. Paris.
} 


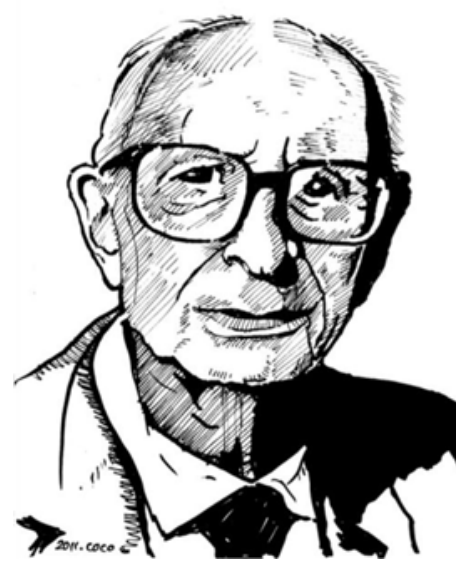

Claude Lévi-Strauss (1908-2009)

difference between people is not due to their being relatives, but the concept of relatives itself. People all over the world appear similarly, through birth, yet they have similar genealogical trees and systems of relatives; thus, the seemingly huge differences between systems of relatives must not be sought in the actual genealogical branches, but in the perception and interpretation of their being relatives.

In his collection of essays published in 1958, Structural anthropology ${ }^{135}$, LéviStrauss makes it absolutely clear that ethnology must not be concerned with the description or historical reconstruction of the rules of culture, but with the scientific description of the primitive mind. He states that although the human brain functions universally, different cultural phenomena are expressions of the cognitive processes characteristic of each culture - so the task is to reveal the patterns of thought.

As an example, Lévi-Strauss takes the distinction between male and female nouns in Indo-European languages, which may have been preserved until present times as the linguistic impression of an ancient religious concept, and which significantly contributes to the fact that in European cultures we tend to think in binary oppositions (e.g. cold-hot, good-bad, heaven-hell, God-Satan, etc.). On the basis of binary oppositions, Lévi-Strauss drew the conclusion that the determination of the relation of concepts logically precedes the interpretation of concepts: we can only interpret phenomena in relation to other, already known things.

"One of my first conversations with Roman Jakobson revolved around the different forms that languages and myths use to express the opposition between the sun and the moon. We tried to discover the contrast in the gender of words indicating the two celestial bodies, as well as in the linguistic turns referring to their size or brightness. We soon had to realize [...] that the binary opposition so obvious for the Western observer appears in especially hidden forms in remote cultures." 136

\footnotetext{
135 Anthropologie structurale, Paris, Plon, 1958.

136 Lévi-Strauss, Claude 1967: Le Sexe des astres. In: 1967: To Honor Roman Jakobson: Essays on the Occasion of His Seventieth Birthday, 11 October 1966. Den Haag, Paris: Mouton, 1163-1170.
} 
Further studies reinforced Lévi-Strauss' suspicion that the binary opposition present in most Indo-European languages is not valid in others. Hungarian nouns do not have a gender, whereas in Swahili, there are as many as 16 genders. A disappearing Australian indigenous language, Dyirbal, puts nouns into four groups according to the following categories: ${ }^{13}$

I. Living things, men

II. Women, water, fire, violence and dangerous things, animals

III. Edible kinds of vegetables and fruit

IV. Others (those that cannot be included in the above categories)

To distinguish between reality and the concepts of reality (as in the real genealogy and culturally created systems of relations in our example), LéviStrauss used the concepts "nature" versus "culture." With this move, he discarded experiments at describing human culture as a set of rules and laws similar to natural sciences. For him, the task of ethnology was to determine the difference between thought and reality. His thoughts partially contradicted contemporary Marxist anthropology. Materialists consider culture as a product of material life, determined by productive forces and relations. LéviStrauss, however, believed that both social and economic systems are given characteristics; thus they are parts of nature. Social scientists should focus indeed on culture, which means the system of concepts that describe the material world.

Lévi-Strauss gave a different meaning to "structure" than the one used by Radcliffe-Brown and his structuralist-functionalist approach. Radcliffe-Brown used the word "structure" to describe the functioning (functional integration) of social institutions, whereas Lévi-Strauss thought of the structures of linguistic and conceptual systems behind cultural differences. Lévi-Strauss often criticized some observations by the former famous anthropologist although the British researcher mostly ignored these. However, this may have been because Lévi-Strauss was not published in English before the end of the 1960s.

\section{Cognitive anthropology}

Cognitive anthropology developed from the 1950s onward, primarily in the USA. Its development was influenced by Lévi-Strauss' structuralism, the

${ }^{137}$ Lakoff, George 1987: Women, Fire, and Dangerous Things: What Categories Reveal About the Mind. Chicago: University Press. 
emergence of Noam Chomsky's generative linguistics, and the advance of cognitive sciences, especially that of experimental psychology.

Noam Chomsky developed his theory of generative grammar in the 1950s. ${ }^{138}$ According to Chomsky, language is not made up of fixed structures but of rules that help us generate, create, or interpret an infinite number of manifestations. Structuralist linguistics can never meet the challenges of syntax because it will never be able to categorize the infinite number of potential versions thereof. The generative trend researches the fundamental rules of syntax - that is, the way thoughts are formed.

D'Andrade divides the development of cognitive anthropology into four bigger phases that preceded the millennium. ${ }^{139}$ In the first phase (the 1950s) it was primarily Ward Goodenough and Anthony Wallace who directed the attention of cultural researchers to linguistic issues. Early cognitivists (as opposed to structuralists) did not seek to describe the structure of ways of thinking; instead, they used language as a key to culture. According to Ward Goodenough, culture (collectively possessed knowledge and sets of information) contains everything there is to know or which is believed to perpetuate behavior that is acceptable to other members of society.

In the second phase, from the 1960s, there was an increase in cognitive anthropological research. I will spare you here a long list of the names of the researchers and only refer in brief to relevant places of research: in the USA, researchers at Columbia, Yale, Harvard University, and UC Berkeley were influential in relation to the subject. Cognitive anthropologists liked to use methods of qualitative content analysis (e.g. so-called categorization or component analysis), and what is more, mathematical-statistical methods appeared in cognitive anthropology in the 1970s. In terms of techniques of data collection, however, the former also put great emphasis on field work and the emic perspective. This coincided with the mainstream of anthropology, since by then (one generation after Boas and Malinowski) field work came to be considered the basis of anthropological data collection.

Cognitivists attribute a special role to language through the following (simplified) explanation: each and every cultural phenomenon comes into being by first thinking about it, then acting upon it; that is, a phenomenon can only be a part of culture if we are able to think about it. Everything we are able think about is accessible to the brain through language, so each cultural phenomenon has its linguistic imprint. To put it the other way round: what is not accessible through language, "does not exist," and cannot be captured

\footnotetext{
Chomsky, Noam 1957: Syntactic Structures. Den Haag: Mouton.

139 d'Andrade, Roy B. 1995: The Development of Cognitive Anthropology. Cambridge UK: University Press.
} 
with the help of culture. Captured in a formula: culture = language, and vice versa, language = culture.

D'Andrade's retrospective work specifies the 1990s as the time of the next two waves of cognitive anthropologists (the third and fourth phase), which also means that the cognitive trend was relatively calm in the seventies and eighties. The greatest challenger of cognitive anthropology was symbolic anthropology.

\section{Symbolic anthropology}

The most serious criticism of the cognitive trend is that its opponents denied the special role of language as the mediator of culture.

In the 1970s, most anthropologists agreed with cognitivists that "culture" is an abstract creation, so their representatives do not perceive it directly, and they also agreed on the point that culture may be captured for participants in symbols imbued with common meanings. It was also universally accepted that the most complex human system of symbols is language. At the same time - and at this point, critics of the cognitive trend raised a warning finger -, culture cannot be solely identified with language, as it must be extended to other symbols of culturally agreed common meaning, such as musical notes, harmonies of colors, dress and hairstyles, home decoration, city structure, and traffic signs. ${ }^{140}$

From the beginning of the 1970s, it was primarily the writings of Victor Turner and Mary Douglas that created the foundations for reinterpreting the research of culture on a symbolic basis. Victor Turner defines symbols as sensually perceivable carriers of meaning and, at the same time, as the totality of meanings. He summarized his views on the subject in The Forest of Symbols, published in 1967. ${ }^{141}$ Turner believed that symbols are the means of expressing and substituting social processes. Turner's research on rituals, for instance, sought to demonstrate the effects of symbols of tribal rituals on the change in the social status of participants.

Mary Douglas says that symbols evoke, interpret, and accompany social changes. One of her ideas was that the human body may be considered the symbol of society, as she believed that everything symbolizes the body, and the body itself symbolizes everything else. The most important thing is how

${ }^{140}$ Colby, Benjamin; James W. Fernandez; David B. Kronenfeld 1981: Toward a convergence of cognitive and symbolic anthropology. New York, Blackwell Publishing.

141 Turner, Victor W. 1967: The Forest of Symbols: Aspects of Ndembu Ritual. Ithaca and London: Cornell University Press. 
members of a given society imagine and perceive the functioning of the body. Rites and cultural habits may be associated with the given social order, since they prescribe and make perceivable the forms of social relationships.

The following extracts are from a piece of writing by Mary Douglas in 1968:142

"There is a whole class of cultures, [...] in which great attention is paid to symbolic demarcation and separation of the sacred and the profane and in which dangerous consequences are expected to follow from neglect of the rituals of separation. In these cultures lustrations, fumigations, and purifications of various kinds are applied to avert the dangerous effect of breach[es] of the rules.

Pollution rules in essence prohibit physical contact. They tend to be applied to products or functions of human physiology... thus they regulate contact with blood, excreta, vomit, hair clippings, nail clippings, cooked food, and so on. [...] It seems that physiological pollutions become important as symbolic expressions of other undesirable contacts which would have repercussions on the structure of social or cosmological ideas. In some societies the social definition of the sexes is more important than in others. In some societies social units are more rigorously defined than in others. Then we find that physical contact between sexes or between social units is restricted even at second or third remove. Not only may social intercourse be restricted, but sitting on the same chair, sharing the same latrine, or using the same cooking utensils, spoons, or combs may be prohibited [...] by pollution beliefs."

Several researchers of society (for instance Herbert Blumer, and Erving Goffman) believed that the role of symbols may be studied during the observation of human relationships. A key concept related to this trend is symbolic interaction, borrowed from psychology, from the works of George $H$. Mead. ${ }^{143}$ According to Mead, the psyche and the self are essentially products of society, and when the self appears in experience, it always emerges in opposition to the other. The masters of symbolic interactionism usually referred to themselves as social psychologists or microsociologists, but their work influenced many cultural anthropologists as well.

142 Douglas, Mary 1968: Pollution. In: International Encyclopedia of the Social Sciences. New York: Macmillan Co. and the Free Press.

${ }^{143}$ Mead, George H.; Charles W. Morris (ed.) 1934: Mind, Self and Society. Chicago: University of Chicago Press. 


\section{The recreation of the concept of culture: culture as a system of symbols}

Capturing culture in symbols was a radically new perspective. Harris, the author of a popular textbook at the end of the 1970s, defined culture as the totality of inherited and learned forms of behavior. Clifford Geertz highlights the intenability of contemporary concepts of culture (1975). ${ }^{144}$

"(It is time) to replace E. B. Tylor's famous 'most complex whole', which, its originative power not denied, seems to me have reached the point where it obscures a good deal more than it reveals. The conceptual morass into which the Tylorean kind of pot-au-feu theorizing about culture can lead, is evident in what is still one of the better general introductions to anthropology, Clyde Kluckhohn's Mirror for Man. In some twenty-seven pages of his chapter on the concept, Kluckhohn managed to define culture in turn as: (1) 'the total way of life of a people'; (2) 'the social legacy the individual acquires from his group'; (3) 'a way of thinking, feeling, and believing'; (4) 'an abstraction from behavior'; (5) 'a theory on the part of the anthropologist about the way in which a group of people in fact behave'; (6) 'a storehouse of pooled learning'; (7) 'a set of standardized orientations to re-current problems'; (8) 'learned behavior'; (9) 'a mechanism for the normative regulation of behavior'; (10) 'a set of techniques for adjusting both to the external environment and to other men'; (11) 'a precipitate of history'; and turning, perhaps in desperation, to similes, as a map, as a sieve, and as a matrix. In the face of this sort of theoretical diffusion, even a somewhat constricted and not entirely standard concept of culture, which is at least internally coherent and, more important, which has a definable argument to make is (as, to be fair, Kluckhohn himself keenly realized) an improvement. Eclecticism is self-defeating not because there is only one direction in which it is useful to move, but because there are so many: it is necessary to choose.

The concept of culture I espouse, and whose utility the essays below attempt to demonstrate, is essentially a semiotic one. Believing, with Max Weber, that man is an animal suspended in webs of significance he himself has spun, I take culture to be those webs, and the analysis of it to be therefore not an experimental science in search of law but an interpretive one in search of meaning. It is explication I am after, construing social expressions on their surface enigmatical."

144 Geertz, Clifford 1973: Thick Description: Toward an Interpretive Theory of Culture. In: The Interpretation of Cultures: Selected Essays, New York, Basic Books, 5. 


\title{
Interpretive anthropology
}

The starting point of interpretive anthropology is an article by Clifford Geertz - Thick Description - published in 1973, quoted above. To understand interpretive anthropology, the present author has selected extracts from this text and one on cock fights in the island of Bali.

\section{Clifford Geertz and thick description}

The concept of thick description is actually a methodological recommendation: namely, a guide to what we should pay attention during field work, and how. Since Geertz is rather straightforward in stating his view, we have not added any commentary to the texts cited here. ${ }^{145}$

\begin{abstract}
"Operationalism as a methodological dogma never made much sense so far as the social sciences are concerned, and except for a few rather well-swept corners Skinnerian behaviorism, intelligence testing, and so on - it is largely dead now. But it had, for all that, an important point to make, however we may feel about trying to define charisma or alienation in terms of operation, retains a certain force: if you want to understand what a science is, you should look in the first instance not at its theories or its findings, and certainly not at what its apologists say about it; you should look at what the practitioners of it do.

In anthropology, or anyway social anthropology, what the practitioners do is ethnography. And it is in understanding what ethnography is, or more exactly what doing ethnography is, that a start can be made toward grasping what anthropological analysis amounts to as a form of knowledge. This, it must immediately be said, is not a matter of methods. From one point of view, that of the textbook, doing ethnography is establishing rapport, selecting informants, transcribing texts, taking genealogies, mapping fields, keeping a diary, and so on. But it is not these things, techniques and received procedures, that define the enterprise. What defines it is the kind of intellectual effort it is: an elaborate venture in, to borrow a notion from Gilbert Ryle, 'thick description."'
\end{abstract}

In order to explain "thick description," Geertz cites Gilbert Ryle's example at length - all the things the closing of an eyelid may mean: a wink or a simple tic, the taunting imitation of winking, or the practice of a parody. In another example, Geertz recalls an old Moroccan case:

145 Geertz, Clifford 1975: Thick Description: Toward an Interpretive Theory of Culture. In: The Interpretation of Cultures: Selected Essays, New York, Basic Books, 5. 


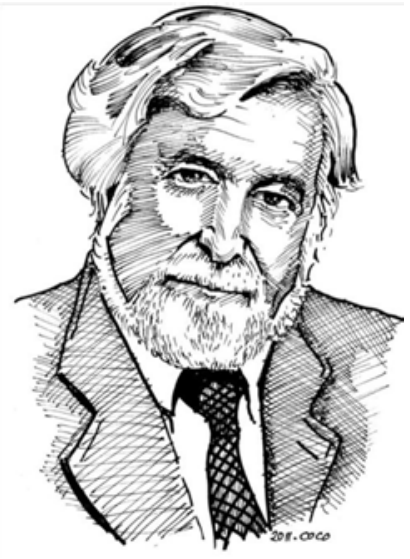

Clifford Geertz

(1926-2006)
"Between the 'thin description' ('rapidly contracting his eyelids') and the 'thick description' ('practicing a burlesque of a friend faking a wink to deceive an innocent into thinking a conspiracy is in motion') lies the object of ethnography: a stratified hierarchy of meaningful structures [...]

Like so many of the little stories Oxford philosophers like to make up for themselves, all this winking, fake-winking, burlesque-fake-winking, rehearsed-burlesque-fake-winking, may seem a bit artificial. In way of adding a more empirical note, let me give, deliberately unpreceded by any prior explanatory comment at all, a not untypical excerpt from my own field journal. [...]

The French - the informant said - had only just arrived. They set up twenty or so small forts between here, the town, and the Marmusha area up in the middle of the mountains, placing them on promontories so they could survey the countryside. But for all this they couldn't guarantee safety, especially at night, so although the mezrag, trade-pact, system was supposed to be legally abolished it in fact continued as before.

One night, when Cohen (who speaks fluent Berber) was up there (at Marmusha) two other Jews who were traders to a neighboring tribe came by to purchase some goods from him. Some Berbers - from yet another neighboring tribe - tried to break into Cohen's place, but he fired his rifle in the air. (Traditionally, Jews were not allowed to carry weapons; but at this period things were so unsettled many did so anyway.) This attracted the attention of the French and the marauders fled.

The next night, however, they came back, and one of them disguised as a woman who knocked on the door with some sort of a story. Cohen was suspicious and didn't want to let 'her' in, but the other Jews said: 'oh, it's all right, it's only a woman.'

So they opened the door and the whole lot came pouring in. They killed the two visiting Jews, but Cohen managed to barricade himself in an adjoining room. He heard the robbers planning to burn him alive in the shop after they removed his goods, and so he opened the door and - laying about him wildly with a club - managed to escape through a window.

He went up to the fort (then) to have his wounds dressed, and complained to the local commandant, one Captain Dumari, saying he wanted his 'ar - i.e. four or five times the value of the merchandise stolen from him. The robbers were from a tribe which had not yet submitted to French authority and were in open rebellion against it, and he wanted authorization to go with his mezrag-holder, the Marmusha tribal 
sheikh, to collect the indemnity that, under traditional rules, he had coming to him. Captain Dumari couldn't officially give him permission to do this - because of the French prohibition of the mezrag relationship - but he gave him verbal authorization saying, 'If you get killed, it's your problem.'

So the sheikh, the Jew, and a small company of armed Marmushans went off ten or fifteen kilometers up into the rebellious area, where there were of course no French, and, sneaking up, captured the thief-tribe's shepherd and stole its herds. The other tribe soon came riding out on horses after them armed with rifles and ready to attack. But when they saw who the 'sheep thieves' were, they thought better of it and said, 'all right, we'll talk.' They couldn't really deny what had happened - that some of their men had robbed Cohen and killed the two visitors - and they weren't prepared to start [a] serious feud with the Marmusha, a scuffle with the invading party would bring on. So the two groups talked, and talked, and talked, there on the plain amid the thousands of sheep, and decided finally on five-hundred-sheep damages. The two armed Berber groups then lined up on their horse at opposite ends of the plain with the sheep herded between them, and Cohen, in his black gown, pillbox hat, and flapping slippers, went out alone among the sheep, picking out, one by one and at his own good speed, the best ones for his payment.

So Cohen got his sheep and drove them back to Marmusha. The French, up in their fort, heard them coming from some distance ('Ba, ba, ba' said Cohen, happily, recalling the image) and said, 'What the hell is that?' Cohen said 'That is my 'ar.' The French couldn't believe he had actually done what he said he had done, and accused him of being a spy for the rebellious Berbers, put him in prison, and took his sheep. In the town, his family, not having heard from him in so long a time, thought he was dead. But after a while the French released him and he came back home, but without his sheep. He then went to the Colonel in the town, the Frenchman in charge of the whole region, to complain. But the Colonel said, 'I can't do anything about the matter. It's not my problem.'

Quoted raw, a note in a bottle, this passage conveys, as any similar one similarly presented would do, a fair sense of how much goes into ethnographic description of even the most elemental sort - how extraordinarily 'thick' it is. [...] (Even to reveal that this little drama took place in the highlands of central Morocco in 1912 - and was recounted there in 1968 - is to determine much of our understanding of it. [...] Right down at the factual base, the hard rock, insofar as there is any, of the whole enterprise, we are already explicating: and worse, explicating explications. Winks upon winks upon winks. [...] What the ethnographer is in fact faced with - except when (as, of course, he must do) he is pursuing the more automatized routines of data collection - is a multiplicity of complex conceptual structures, many of them superimposed upon or knotted into one another. [...] Doing ethnography is like trying to read (in the sense of 'construct a reading of') a manuscript - foreign, faded, full of ellipses, incoherencies, suspicious emendations, and tendentious commentaries, but 
written not in conventionalized graphs of sound but in transient examples of shaped behavior.

Culture, this acted document, thus is public, like a burlesqued wink or a mock sheep raid. Though ideational it does not exist in someone's head; though unphysical is not an occult entity. The interminable, because interminable, debate within anthropology as to whether culture is 'subjective' or 'objective', together with the mutual exchange of intellectual insults ('idealist!' - 'materialist!'; 'mentalist!'; 'behaviorist!'; 'impressionist!' -'positivist!') which accompanies it, is wholly misconceived. Once human behavior is seen as (most of the time; there are true twitches) symbolic action which, like phonation in speech, pigment in painting, line in writing, or sonance in music, signifies, the question as to whether culture is patterned conduct or a frame of mind, or even the two somehow mixed together, loses sense. The thing to ask about a burlesqued wink or a mock sheep raid is not what their ontological status is. [...] The thing to ask is what their import is: what it is, ridicule or challenge, irony or anger, snobbery or pride, that in their occurrence and through their agency, is getting said.

The article that became a cornerstone of interpretive anthropology, Thick Description, thus states that in doing symbolic anthropology, we must ensure that the meanings attributed to events that are observed are not distorted but are recorded in their entirety, both during field work and during the publication of results. We illustrate the meaning of thick description in practice with an earlier piece of writing by Geertz - his report on a cock fight on the island of Bali (1972).

Clifford Geertz arrived on the island of Bali in 1958; he was on a honeymoon with his wife and they carried out field work in a tiny village. The self-conscious Balinese ignored the anthropologist couple for a long time (to use an expression borrowed from Margaret Mead: "he is away"). But when the police attacked the locals during an illegal cock fight, and the honeymooners fled with the locals, this proved to be a good entrée. From then on, Clifford Geertz was a regular visitor at cock fights, and often made bets and learned the local betting customs.

As it turned out, the betting customs of the Balinese are not solely influenced by a greed for profit; by betting, they undertake a complicated social obligation. It often happened that somebody bet on a cock out of solidarity with a teammate, despite knowing that the animal stood no chance. Things became a little more complicated when one of the scions of your cock was on the rival team, and you knew he had no chance to win, yet you still placed a small bet on it to show that you always trust your cock and its scions. Your team members do not judge you for this, but the small stake undermines the trust in your cocks and you may deter potential customers. 
Clifford Geertz payed great attention to precisely recording and presenting the rich vocabulary and widespread meanings about Balinese betting culture. The essay is almost like a dictionary for betting on cocks: it helps us learn more than a dozen Balinese expressions, with the meanings explained in minute detail, such as in the case of the word cock (sabung):

"To anyone who has been in Bali any length of time, the deep psychological identification of Balinese men with their cocks [is] unmistakable. [...] The language of everyday moralism is shot through, on the male side of it, with roosterish imagery. Sabung, the word for cock [...] is used metaphorically to mean 'hero', 'warrior', 'champion', 'man of parts', 'political candidate', 'bachelor', 'dandy', 'lady-killer', or 'tough guy.' A pompous man whose behavior presumes above his station is compared to a tailless cock who struts about as though he had a large, spectacular one. A desperate man who makes a last, irrational effort to extricate himself from an impossible situation is likened to a dying cock who makes one final lunge at his tormentor to drag him along to a common destruction. A stingy man, who promises much, gives little, and begrudges that is compared to a cock which, held by the tail, leaps at another without in fact engaging him. A marriageable young man still shy with the opposite sex or someone in a new job anxious to make a good impression is called 'a fighting cock caged for the first time'. Court trials, wars, political contests, inheritance disputes, and street arguments are all compared to cockfights. Even the very island itself is perceived from its shape as a small, proud cock, poised, neck extended, back taut, tail raised, in eternal challenge to large, feckless, shapeless Java." ${ }^{146}$

We know of several examples from before the work of Geertz when the results of ethnographical-anthropological research moved into the researched culture as concepts, making it fertile and richer. From our earlier examples: James Cook's travels, or Freud's lecture Totem and Taboo, which significantly contributed to the expression taboo taking root in European languages.

Since Geertz's appearance, however, anthropologists have consciously tried to integrate concepts differing from theirs and their logical structure into their own language environment as faithfully to the original as possible (see boxed text).

146 Geertz, Clifford 1972: Deep Play: Notes on the Balinese Cockfight. Daedalus, 101/1, 1-37. 
The possibilities for understanding and interpretation *1

"The concept of culture I espouse - writes Clifford Geertz"2 -, is essentially a semiotic one. Believing, with Max Weber, that man is an animal suspended in webs of significance he himself has spun," ${ }^{3}$ । take culture to be those webs, and the analysis of it to be therefore not an experimental science in search of law but an interpretive one in search of meaning."

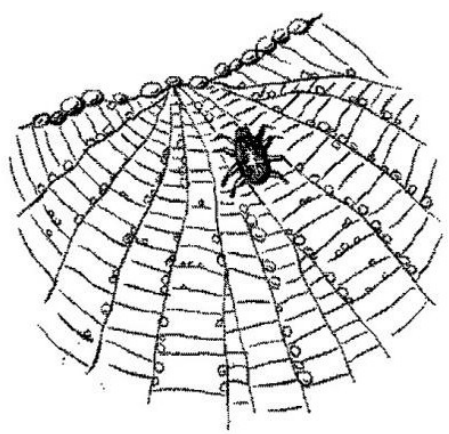

From the 1950s onwards, cultural anthropologists increasingly tried to examine the meanings generating social behavior, not behavior itself. According to the above-cited essay by Geertz, for instance, man does not behave, act, etc. but imbues his behavior and acts with significance. Socially constructed meanings are fixed from the point of view of the individual. The system of meanings is the "spider web" that determines and structures our thinking. In a broad sense, the web of meaning is culture (customs, gestures, rules etc.); in a narrow sense it is language. According to the cognitive approach, we can only think of things we have words for, while we try to put unknown feelings or new knowledge into words.

* Drawings by lldikó Takács.

** Geertz, Clifford 1975: Thick Description: Toward an Interpretive Theory of Culture. In: The Interpretation of Cultures: Selected Essays, New York, Basic Books, 5.

*** Geertz usually wrote impulsively and only loosely referenced. We would never find the reference to the animal suspended in webs of significance in Weber's works, but the message contained in several of his pieces of writing may be summarized this way. In his introduction to Emphatic sociology, Marx Weber says: "1. §. Sociology (the way we use this word of many meanings) is the discipline which aims at the interpretive understanding of social acts and, through that, at explaining the process and effects of such acts. 


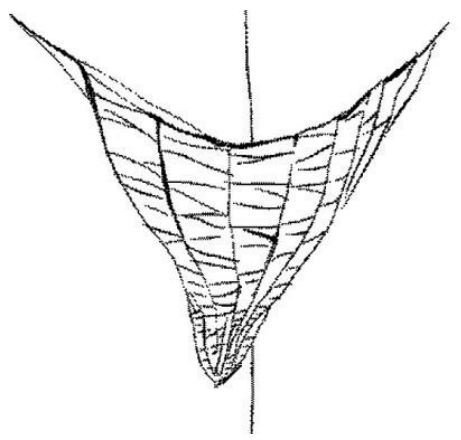

A different culture means a different web of significance. It is the anthropologist's task to associate one web with the other. This association is interpretation that interpretive anthropology was named after. Apart from the difficulties of anthropological data collection and understanding, interpretation itself is difficult. A culture and its elements may not be interpreted for another culture in its full context even in theory. This task is like integrating a spider web spun in the corner with the circular web of a cross spider. The end result can only reflect the observed culture to the degree that a photograph of a spider web spun in the corner resembles the three dimensional original. The next best solution is to seek an interpretation that is as faithful to the original context as possible.

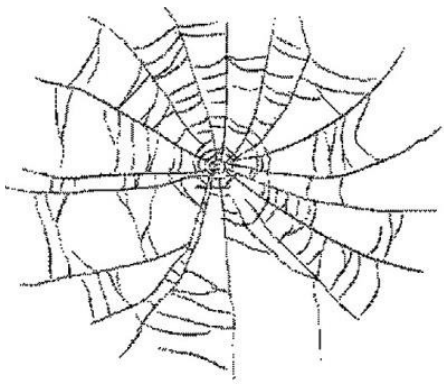

The world that may be captured by our words and culture is presumably much smaller than the world of feelings and knowledge unavailable to us, just like the space around a spider web is bigger than the web itself. A finite set of knowledge is faced with an infinite unknown. Anthropology, however, cannot set out to know the unknown, for instance, it cannot create new words to capture feelings or knowledge so far unknown. (This is primarily a task for artists and scientists.) During his work, the anthropologist must cast aside imagination, as he can only seek to get to know and interpret as faithfully as possible meanings already existing in other cultures.

By 'act' we mean all human behavior (be it outer or inner activity, the missing or tolerance of something) if and when the actor or actors associate some subjective meaning to it. A 'social' act is an act that concerns the behavior of others according to the intended meaning of the actor or actors and its process is adapted to the behavior of others.

Weber, Max 1922: Wirtschaft und Gesellschaft.

Grundriss der verstehenden Soziologie. 1. Halbband. Tübingen: J. C. B. Mohr (Paul Siebeck). 


\section{Postmodern}

The aforementioned trends (symbolic anthropology, or the interpretive approach) do not belong to one school of the history of ideas but are umbrella terms for similar approaches.

In the case of postmodern approaches, the name suggests a concept even more loose and heterogeneous than the aforementioned umbrella terms.

Social sciences borrowed the term "postmodern" from the revolution in the fine arts in the 1970s, and (just like in the arts), these trends have one single common characteristic: they all turned against modernism. In social sciences, the postmodern turn mainly means that these disciplines reject the positive tradition of Auguste Comte - they deny, that is, that the world may be known objectively. In cultural anthropology, the possibility of obtaining objective knowledge was slowly replaced by the idea of the subjective nature of knowledge from the 1970s onwards.

Our starting point is once again Clifford Geertz. An essay of his was prompted by the publication and scandalous reception of Malinowski's secret diary in 1974. ${ }^{147}$

"Several years ago a minor scandal erupted in anthropology: one of its ancestral figures told the truth in a public place. [...] Bronislaw Malinowski's A Diary in the Strict Sense of the Term rendered established accounts of how anthropologists work fairly well implausible. The myth of the chameleon fieldworker, perfectly self-tuned to his exotic surroundings, a walking miracle of empathy, tact, patience, and cosmopolitanism, was demolished by the man who had perhaps done most to create it.

[...] Most of the shock seems to have arisen from the mere discovery that Malinowski was not, to put it delicately, an unmitigated nice guy. He had rude things to say about the natives he was living with, and rude words to say it in. [...]

The squabble concentrated on inessentials and missed the point. The issue the diary presents is not moral. The issue is epistemological. [...] As a matter of fact, this general problem has been exercising methodological discussion in anthropology for the last ten or fifteen years. The formulations have been various: 'inside' versus 'outside' or 'first person' versus 'third person' descriptions; 'phenomenological' versus 'objectivist' or 'cognitive' versus 'behavioral' theories; or, perhaps most commonly 'emic' versus 'etic' analyses, this last deriving from the distinction in linguistics between phonemics and phonetics."

According to Geertz, anthropologists idealized the emic perspective, expecting the anthropologist to have great emphatic abilities, to brilliantly

147 Geertz, Clifford 1974: "From the Native's Point of View": On the Nature of Anthropological Understanding. Bulletin of the American Academy of Arts and Sciences, 28/1, 26-45. pp. 
adapt to those living in the field. This is not always possible, nor - and this is more important - necessary.

"The trick is not to get yourself into some inner correspondence of spirit with your informants. The trick is to figure out what the devil they think they are up to. [...] In all three of the societies I have studied intensively, Javanese, Balinese, and Moroccan, I have tried to get at this most intimate of notions not by imagining myself someone else, a rice peasant or a tribal sheikh, and then seeing what I thought, but by searching out and analyzing the symbolic forms.

When an explication de texte critic like Leo Spitzer attempts to interpret Keats's 'Ode on a Grecian Urn', he does so by repetitively asking himself the alternating question 'What is the whole poem about?' and 'What exactly has Keats seen (or chosen to show us) depicted on the urn he is describing?', emerging at the end of an advancing spiral of general observations and specific remarks with a reading of the poem as an assertion of the triumph of the aesthetic mode of perception over the historical. [...] All this is, of course, but the now familiar trajectory of what Dilthey called the hermeneutic circle.

[...] But whatever accurate or half-accurate sense one gets of what one's informants are, as the phrase goes, really like does not come from the experience of that acceptance as such, which is part of one's own biography, not of theirs. It comes from the ability to construe their modes of expression, what I would call their symbol systems, which such an acceptance allows one to work toward developing. Understanding the form and pressure of, to use the dangerous word one more time, natives' inner lives is more like grasping a proverb, catching an allusion, seeing a joke - or, as I have suggested, reading a poem - than it is like achieving communion."

Hermeneutics, the discipline of the interpretation of meanings, had a great influence on twentieth century philosophy and social sciences. Cultural anthropology has demonstrated the effects of hermeneutics since the 1970s. The hermeneutical turn of anthropology manifested itself in the fact that anthropologists rejected the concept that the world may be known objectively and neutrally. The idea that we may get acquainted with other cultures may be challenged on a hermeneutical basis because - since we cannot separate our knowledge from our language and culture-, we do not see beyond the contexts of our own culture. The fundamental asymmetry of cultural anthropology educated people research the uneducated, primarily white people research the colored - means, according to hermeneutical criticism, that anthropology is the discipline of educated white men, its field of interpretation thus does not exceed the world of educated white men. Hermeneutical criticism was reinforced in the 1970s by a trend concerned with social genders, first called feminist anthropology (see boxed text). 
According to postmodern criticism, anthropologists have never been objective observers of cultures, since their subject left its mark on their observations even during the phase of field work. This is why the 1970s saw a whole series of retro research (research by famous anthropologists carried out once again). For instance, in 1983 in Samoa, Derek Freeman reached conclusions that entirely contradicted those of Margaret Mead; the aim of his article was not to shatter Mead's reputation but to illustrate how a researcher of culture of a different perspective may draw different conclusions regarding the same area. ${ }^{148}$

Modernist anthropology was even more seriously criticized for its practice of data processing and publication. Marcus and Cusman (1982) are firmly against the position of the narrator - that is, the idea of a seemingly objective, third-person singular report. The narrator does not draw on his direct observation to write: "I see my informant pour ketchup on his ice cream"; instead, he writes: "the inhabitants of San Marcos pour ketchup on their ice cream." "199

148 Freeman, Derek 1983: Margaret Mead and Samoa: The Making and Unmaking of an Anthropological Myth. Cambridge MA: Harvard University Press. Freeman, Derek 1999: The Fateful Hoaxing of Margaret Mead: A Historical Analysis of Her Samoan Research. Boulder: Westview Press.

149 Marcus, George; Dick Cushman 1982: Ethnographies as Texts. Annual Review of Anthropology, 11, 25-69. o. Cited by: McGee, R.; Jon and Richard L. Warms 2004: Anthropological Theory: An Introductory History. New York: McGraw Hill. 
Feminist anthropology and postmodernity

\section{By Hoffer Ádám}

The history of feminism goes all the way back to the middle of the nineteenth century, to the struggle for education, work, and the right to vote. Over time, the objectives of equality expanded, and by the second half of the twentieth century, feminism possessed one of the strongest programs of critical thinking.

Feminism appeared in anthropology in the 1970s. Feminist anthropology studies female roles and the position of the female body in different cultures. For instance, Sherry B. Ortner (1974) ${ }^{410}$ compares the opposition of culture versus nature to the relationship between men and women in different cultures. According to Ortner's analysis, women symbolically engage with nature, while men represent culture. Just as male-dominated culture suppresses natural resources, it also forces women into a subordinate position.

In the 1980s, feminism, and with it, the anthropological research of the situation of women, were transformed. Postmodern restructuring made feminists realize the problems of complex categories. Feminism enlarged its horizon: the binary opposition between man and woman was further sliced up by characteristics such as social situation, ethnic group," ${ }^{2}$ education, religion, and last but not least, sexual orientation. This put an end to "feminism" and replaced it with gender studies and women's studies.

* Ortner, Sherry B. 1974: Is Female to Male As Nature is to Culture? In: Rosaldo, M. Z.; Lamphere L. (ed.): Woman, Culture, and Society. Stanford: University Press, 68-87. pp.

** Sa'di, Ahmad H.; Lila Abu-Lughod (ed.) 2007: Nakba: Palestine, 1948, and the Claims of Memory. New York: Columbia University Press.

Vincent Crapanzano's starting point is that ethnographical data are mute they only receive meaning thanks to the work of the anthropologist. This is why in his essay, Hermes' Dilemma, (1986) ${ }^{150}$ Crapanzano chose to analyze

150 Crapanzano, Vincent 1984: Hermes' Dilemma: The Masking of Subversion in Ethnographic Description. In: Clifford, James; George Marcus (ed.): Writing Culture. The Poetics and Politics of Ethnography. Berkeley etc.: University of California Press, 51-76. See also: Crapanzano, Vincent 1992: Hermes' Dilemma and Hamlet's Desire: On the Epistemology of Interpretation. Cambridge MA: Harvard University Press. 


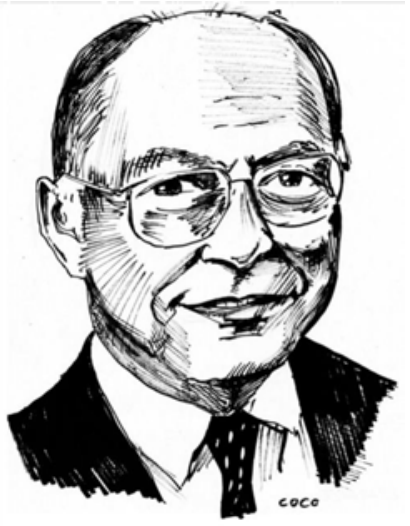

Vincent Crapanzano (1939-) reports by several anthropologists, among others, Geertz's study on Balinese cock fighting.

Geertz's text - writes Crapanzano is all the less objective since he used the description of the cock fight by way of demonstration to reach his scientific goals.

The latter raises several problems with the text, such as

- There is no feedback, we do not know the locals' opinion on the written text;

- Geertz describes the Balinese village without taking into account his own effect on the community.

Both problems are illustrated by the part of Geertz' text where he says that he was ignored (treated as if "he is away") by the Balinese. Crapanzano thought that this description was inauthentic: just because Geertz felt this way, the Balinese may have thought otherwise. This could have been avoided by feedback, by checking the written text on the spot.

By the 1990s, following the postmodern turn, the mainstream of cultural anthropology generally accepted - in essays and films - the control of the researcher's opinion, feedback, and the precise presentation of the role they play during anthropological field work. Another important element is the explanation of the learning process of the researcher - a classic example is Renato Rosaldo's study, Grief and a Headhunter's Rage (1989). ${ }^{151}$

"When llongots told me, as they often did, how the rage in bereavement could impel men to headhunt, I brushed aside their one-line accounts as too simple, thin, opaque, implausible, stereotypical, or otherwise unsatisfying. Probably I naively equated grief with sadness. Certainly no personal experience allowed me to imagine the powerful rage llongots claimed to find in bereavement.

[...] In my efforts to find a 'deeper' explanation for headhunting, I explored exchange theory, perhaps because it had informed so many classic ethnographies. [...] One day, I explained the anthropologist's exchange model to an older llongot man named Insan. What did he think, I asked, of the idea that headhunting resulted from the way that one death canceled another... Insan reflected a moment and replied that

Rosaldo, Renato 1989: Culture and Truth: The Remaking of Social Analysis. Boston: Beacon Press. Annotated edition: McGee, R. Jon; Richard L. Warms 2004: Anthropological Theory: An Introductory History. New York: McGraw Hill. 
he imagined somebody could think such a thing [...] but that he and other llongots did not think any such thing. Nor was there any indirect evidence for my exchange theory in ritual, boast, song, or casual conversation.

[...] In 1981 Michelle Rosaldo [the author's wife] and I began field research among the Ifugaos of northern Luzon, Philippines. On October 11 of that year, she was walking along a trail with two Ifugao companions when she lost her footing and fell to her death some 65 feet down a sheer precipice into a swollen river below. Immediately on finding her body I became enraged. How could she abandon me? [...] I sobbed, but rage blocked the tears. Less than a month later I described this moment in my journal: 'I felt like in a nightmare, the whole world around me expanding and contracting, visually and viscerally heaving. Going down I find a group of men. [...] standing still, silent, and I heave and sob..."”

One of the anthropological bestsellers of recent decades is Nigel Barley's book, The Innocent Anthropologist. ${ }^{152}$ The entertaining style and the proportions of content are quite remarkable: more than half of the report consists of personal experiences such as how the author bought a run-down jeep, how his hygiene-related habits changed, and how he broke two of his teeth. We hardly learn anything about the doajos, the people he studied.

These proportions may be a bit exaggerated, but all anthropological reports must reflect the conditions of field work and the researcher's relation to the topic.

"I had decided to hold my own farewell party in the village. To his end, some forty bottles of beer had been obtained by devious means and Mariyo had agreed to brew a quantity of millet beer. This, of course, became a major problem in true Dowayo fashion. [...] The upshot of it all was that it was only at the very last minute that the millet was brought and the beer made. For two days the village was buzzing with excitement. [...] Children ran hither and thither borrowing calabashes and jars and generally getting under everyone's feet. They were especially keen to snap up anything I threw away. [...] Men kept dropping by just to look at the beer and spread the word. All in all, the party was a wild success. [...] Soon the whole village was riotously drunk. [...] Two of the Chief's wives crouched at my feet and began to weep; the drummer knelt before me and pounded out an ever more insistent beat in the flickering firelight; the dancers circled... It seemed to me that some response was being called for. [...] Miraculously, Matthieu appeared behind me with a handful of hundred-franc coins. 'Press a coin to each forehead, patron!' he hissed. I did as I was bid... I intoned a blessing, 'May your forehead be lumpy' - a sign of good fortune.

152 Barley, Nigel 1983: The Innocent Anthropologist: Notes from a Mud Hut. London: British Museum Press. 
[...] Matthieu and I retired to the hut where Zuuldibo and other worthies were assembled ... We then had to sit drinking for several hours although I desperately wanted the hard solitude of my bed. [...] I had been rendered virtually teetotal through hepatitis. [...] Soon I was alone and tumbled gratefully into bed. It began to rain. The roof began leaking again." 

Intellectual endeavors and an accumulation of knowledge are pursued in this exciting introduction to a science that studies the cultural diversity of mankind. A rare virtue of the work is that it also shows how the need to develop national ethnographies is related to cultural anthropology as it is applied to the comprehensive study of humanity.

Sárkány, Mihály

Committee on Ethnography

Hungarian Academy of Sciences

Die Kulturanthropologie beschäftigt sich vor allem mit dem Verstehen anderer Kulturwelten. Es geht demzufolge um Übersetzung. Daher ist es für deutsche Studierende außerordentlich spannend, dass diese Einleitung aus dem Ungarischen übersetzt wurde. Allgemeine Trends werden in diesem Land widergespiegelt, wie zum Beispiel das Verhältnis der vergleichenden Anthropologie zur Volkskunde und zur Nation.

Cultural anthropology is primarily concerned with understanding other cultures. It is therefore about translation. It will therefore be extremely exciting for German readers that this introduction has been translated from Hungarian. General trends are reflected in this country, such as the relationship of comparative anthropology to folklore and to the nation.

Hann, Chris

director of Max Planck Institute for Social Anthropology

(Foreword for the German edition, 2020.)

A kulturális antropológiát több okból is nehéz oktatni. Nálunk ez a szakterület sokáig ideológiai elhárításban részesült, „elbújtatva” a néprajzon belül, az önálló képzés csak a nyolcvanas években indult meg e szakágban. Manapság azonban nagyon népszerü és a legtöbb társadalomtudományi oktatásban tantárgy is. Már sok szakkönyv megjelent a tárgyban, de az angol nyelvröl fordított néhány tankönyv nem vált be igazán. A szerző, Letenyei László a Corvinus Egyetemen oktat kulturális antropológiát, és e tankönyvben újszerü és eredeti megközelítéssel próbálkozott. Modern módon „amerikaias” a szöveg, amelyek megírásába a szerző diákokat is bevont.

Cultural anthropology is difficult to teach for several reasons. This field was ideologically rejected in Eastern Europe for a long time, "hidden" within ethnography - self-education started in this field only in the 1980s. Today, however, it is a very popular subject in social science education. Textbooks translated from English have not really worked. The present author, László Letenyei, teaches cultural anthropology at Corvinus University, and has applied an original approach with this handbook. In a modern way, the text is "American", the writing of which also involves the contributions of students.

Buda, Béla

(critique on the Hugarian edition; Élet és Irodalom, 2012) 